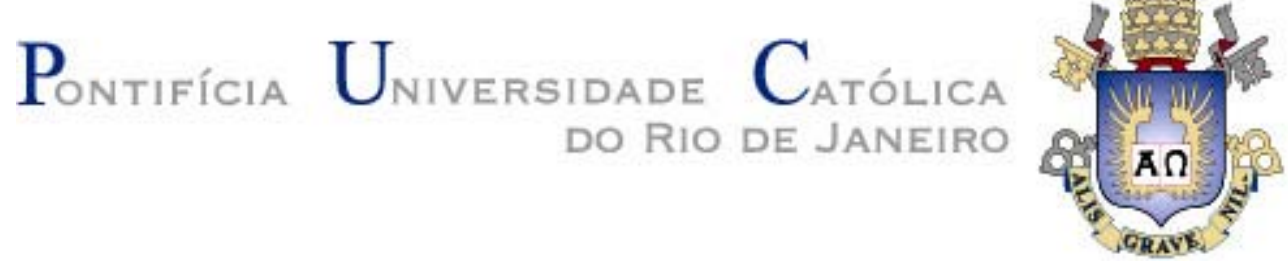

Cristina Trencher da Silva

Influência da Liderança na Fase de Amadurecimento do Ciclo de Vida Organizacional - A influência do perfil de liderança do tomador de decisão no desempenho de organizações em estágio amadurecimento

Dissertação de Mestrado

Dissertação apresentada como requisito parcial para obtenção do grau de Mestre pelo Programa de Pósgraduação em Administração de Empresas do Departamento de Administração da PUC-Rio.

Orientadora: Profa ${ }^{a}$ Patrícia Amélia Tomei

Rio de Janeiro Dezembro de 2015 
Cristina Trencher da Silva

\title{
Influência da Liderança na Fase de Amadurecimento do Ciclo de Vida Organizacional - A influência do perfil de liderança do tomador de decisão no desempenho de organizações em estágio amadurecimento
}

Dissertação apresentada como requisito parcial para obtenção do grau de Mestre pelo Programa de PósGraduação em Administração de Empresas do Departamento de Administração da PUC-Rio. Aprovada pela Comissão Examinadora abaixo assinada.

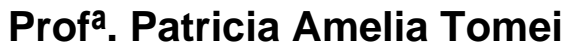 \\ Orientadora \\ Departamento de Administração - PUC-Rio
}

Profa. Ana Heloísa da Costa Lemos

Departamento de Administração - PUC-Rio

Prof. Helio Arthur Reis Irigaray

FGV

Prof $^{a}$. Mônica Herz

Vice-Decana de Pós-Graduação do CCS - PUC-Rio

Rio de Janeiro, 21 de dezembro de 2015 
Todos os direitos reservados. É proibida a reprodução total ou parcial do trabalho sem autorização da universidade, da autora e da orientadora.

\section{Cristina Trencher da Silva}

Graduada em Administração Empresas pela Universidade Mackenzie (São Paulo, 1999), Pós-graduada em Gestão de Informática pela FGV-SP (2000), Certificada pelo PMI (Project Management Professional Certification) desde 2004, e pelo IMD (International Institute for Management Development) no Business Programs Mastering Leadership Challenges Program (2012), com MBA (Management) pelo IAG PUC-RJ (2013).Profissional com mais de 15 anos atuação em multinacionais na área de projetos, sendo responsável por incorporações de novas empresas, expansões de negócios, processos e desinvestimentos em 6 países das Américas, como gerente sênior por projetos internacionais, implementação de ERP e padronização de processos de RH ,TI, Suprimentos, Finanças..

Ficha Catalográfica

Silva, Cristina Trencher da

Influência da liderança na fase de amadurecimento do ciclo de vida organizacional: a influência do perfil de liderança do tomador de decisão no desempenho de organizações em estágio amadurecimento / Cristina Trencher da Silva ; orientadora: Patrícia Amélia Tomei. 2015.

119 f. : il. color. ; $30 \mathrm{~cm}$

Dissertação (mestrado)-Pontifícia Universidade Católica do Rio de Janeiro, Departamento de Administração, 2015.

Inclui bibliografia

1. Administração - Teses. 2. Perfil de liderança. 3. Indicadores de desempenho. 4. Ciclo de vida organizacional. I. Tomei, Patrícia Amélia. II. Pontifícia Universidade Católica do Rio de Janeiro. Departamento de Administração. III. Título. 


\section{Agradecimentos}

Agradeço a Deus e a todos que me apoiaram na participação e conclusão desse mestrado.

Aos professores pela competência em dividir experiências e sabedoria, principalmente a professora Patrícia Tomei, por toda orientação e atenção dedicada a realização esse trabalho. 


\section{Resumo}

Silva, Cristina Trencher da; Tomei, Patrícia Amélia. Influência da Liderança na Fase de Amadurecimento do Ciclo de Vida Organizacional - A influência do perfil de liderança do tomador de decisão no desempenho de organizações em estágio amadurecimento. Rio de Janeiro, 2015. 119p. Dissertação de Mestrado - Departamento de Administração, Pontifícia Universidade Católica do Rio de Janeiro.

A confirmação de que existe uma relação positiva entre o estilo de liderança e o desempenho organizacional não é uma unanimidade nos trabalhos do tema, mas a maioria das pesquisas enfatiza que líderes transformacionais, colaborativos e participativos são fundamentais para o sucesso de uma organização. Para aprofundar a questão este trabalho analisa a influência do estilo de liderança nas decisões tomadas durante o ciclo de vida de uma organização considerando: (a) os ciclos de vida organizacional, (b) as características liderança que os tomadores de decisão possuem e expressam, e (c) indicadores de desempenho. Foi realizado um estudo longitudinal combinando uma abordagem qualitativa e quantitativa para analisar duas pequenas empresas familiares cariocas do comércio varejista, escolhidas segundo conveniência e acessibilidade. Os casos selecionados focaram em empresas na fase de amadurecimento segundo o modelo de Greiner (1998) na quais foram aplicados questionários elaborados a partir dos pilares de liderança situacional de Bass (1990) e com base nas questões de Pillai et al. (1999). Concluímos que existe um indicativo de relação positiva entre estilo de liderança do tomador de decisão e o desempenho, e que a liderança transformacional da empresa "B" em média gerou melhores resultados do que na empresa "A" com uma liderança transacional. Por fim, o estudo sugere também que um estilo de liderança transformacional que se sobrepõe a um estilo liderança transacional apresenta ser no estágio de amadurecimento das empresas um diferencial para o resultados alcançados.

\section{Palavras-chave}

Perfil de liderança; indicadores de desempenho; ciclo de vida organizacional 


\section{Abstract}

Silva, Cristina Trencher da; Tomei, Patrícia Amélia (Advisor). The Influence of Leadership at Maturing Phase of Organizational Life Cycle - The influence of the decision maker leadership profile on the performance organization in maturing stage. Rio de Janeiro, 2015. 119p. MSc. Dissertation - Departamento de Administração, Pontifícia Universidade Católica do Rio de Janeiro.

The confirmation that there is a positive relationship between leadership style and organizational performance is no unanimity in the field, but most researches emphasizes that transformational, collaborative and participatory leaders are critical to the success of an organization. To examine the question this dissertation analyzes the influence of leadership style on the decisions made during the life cycle of an organization considering: (a) the organizational life cycles, (b) the characteristics of leadership that decision makers have and express, and (c) performance indicators. A longitudinal study was carried out by combining a qualitative and quantitative approach to analyze two small Rio de Janeiro family businesses in the retail trade, chosen according to convenience and accessibility. The selected cases focused on companies in their maturing stage according to Greiner's model (1998) which we reapplied questionnaires designed from the situational leadership pillars of Bass (1990) and based on the questions of Pillai et al. (1999). The conclusions were that there is a positive relationship between leadership style of the decision maker and performance, and that the transformational leadership of the company "B" on average generated better results than the company "A" with a transactional leadership. Finally, the study also suggests that a transformational leadership style that overlaps a transactional leadership one, seems to be a differential to the organizational results.

\section{Keywords}

Leadership profile; performance indicators; organizational lifecycle. 


\section{Sumário}

1 Introdução 13

1.1. Objetivo final 15

1.2. Objetivos Intermediários 15

1.3. Delimitação do estudo 16

1.4. Relevância do estudo 16

2 Referencial teórico $\quad 17$

2.1. A Utilidade dos Ciclos de Vida de Organizacionais 18

2.2. Modelos de Ciclo de Vida Organizacional e as Características das

Fases 19

2.3. A Aplicação do Modelo de Ciclo de Vida Usando a Cinco Fases do Ciclo de Vida Como Diferenciais 26

2.4. As Fases do Ciclo, suas demanda e as necessidades do mercado 27

2.4.1. Fase 1: Criar (Start-up) 27

2.4.2. Fase 2: Direção (Crescimento) 28

2.4.3. Fase 3: Delegação (Amadurecimento) 29

2.4.4. Fase 4: Coordenar (Sustentação) 29

2.4.5. Fase 5: Declínio ou Reinventar 30

2.5. O papel das características de liderança em um modelo de Ciclo $\begin{array}{ll}\text { de Vida } & 31\end{array}$

2.6. As principais correntes sobre liderança 32

2.6.1. Teoria dos Traços de Personalidade 32

2.6.2. Teoria Comportamentais 33

2.6.2.1. Teoria dos Estilos de Liderança (White e Lippitt, 1939) 33

2.6.2.2. Grid Gerencial (Blake e Mouton,1964) 34

2.6.3. Teorias Contingenciais 36

2.6.3.1. Teoria do caminho-objetivo 36

2.6.3.2. Teorias Situacionais $\quad 37$

2.6.4. Evolução das Teorias Contingências 39

2.6.5. Liderança Autêntica 43

2.6.6. Liderança e o Desempenho Organizacional 44 
2.7. Teorias Sobre o Desempenho 46

2.7.1. Definições 46

2.7.2. Importância do estudo do desempenho 46

2.7.3. Problemas e Limitações em Medir o Desempenho 47

2.7.4. Classificação dos Indicadores de Desempenho 48

2.7.5. Indicadores Financeiros de Desempenho 49

2.7.6. Indicadores não Financeiros de Desempenho 50

2.7.7. Indicadores Híbridos de Desempenho (Financeiro e Não Financeiro) 52

2.7.8. Indicador de Desempenho para Pesquisa 57

3 Metodologia 58

3.1. Tipo de pesquisa $\quad 58$

3.2. Seleção dos sujeitos $\quad 59$

3.3. Procedimento e Instrumentos de Coletas de dados 60

3.4. Análise dos dados 63

3.5. Limitações do estudo (Limitações do método) 65

4. Análise e Interpretação dos Resultados 66

4.1. A empresa (Contextualização do objeto de pesquisa) 66

4.1.1. Empresa "A": 66

4.1.2. Características Gerais 66

4.1.3. Papel do Fundador 67

4.1.4. Missão, visão e valores organizacionais 69

4.1.5. Estrutura Organizacional $\quad 71$

4.1.6. Estratégia organizacional 72

4.2. Política de Recursos Humanos 73

4.2.1. Contratação 73

4.2.2. Remuneração 73

4.2.3. Treinamento 74

4.3. Comunicação Organizacional 75

4.4. Processo de Trabalho $\quad 75$

4.5. Estágio de vida da Empresa "A" 76

4.6. Empresa "B" 78 
4.6.1. Características Gerais 78

$\begin{array}{ll}\text { 4.6.2. Papel do Fundador } & 79\end{array}$

4.6.3. Missão, visão e valores organizacionais. 81

4.6.4. Estrutura Organizacional 83

4.6.5. Estratégia organizacional 85

4.7. Política de Recursos Humanos $\quad 85$

4.7.1. Contratação $\quad 85$

4.7.2. Remuneração 86

4.7.3. Treinamento 86

4.8. Comunicação Organizacional 87

4.9. Processo de Trabalho $\quad 87$

4.10. Estágio de vida da Empresa "B" 87

4.11. Descrição dos resultados 89

4.11.1. Estilos de Liderança 90

4.11.2. Desempenho Organizacional 93

5 Conclusão 101

5.1. Sugestões e recomendações para novas pesquisas 104

6 Referências Bibliográficas $\quad 105$

$\begin{array}{ll}\text { Anexo } 1 & 113\end{array}$ 


\section{Lista de figuras}

Figura 1: Modelo de ciclo de vida organizacional.......................................2 27

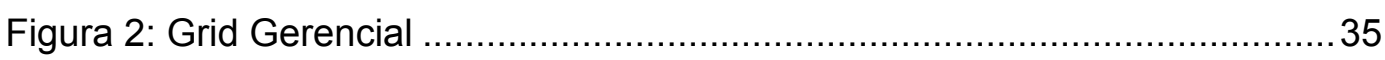

Figura 3: Modelo de liderança situacional de Tannenbaum e Schmidt. .............. 37

Figura 4: Modelo de liderança situacional de Hersey e Blanchard......................39

Figura 5: Modelo das variáveis que influenciam o desempenho organizacional

Erro! Indicador não definido.

Figura 6: Modelo de desempenho de Venkatraman e Ramanujam .53

Figura 7: Correlação entre mecanismos de pesquisa do desempenho e fonte. .54

Figura 8: Modelo de desempenho de clima organizacional $x$

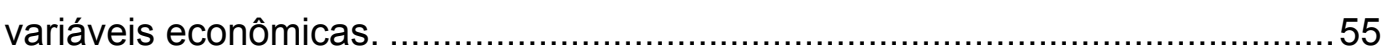

Figura 9: Modelo de cultura organizacional e efetividade. ..............................55

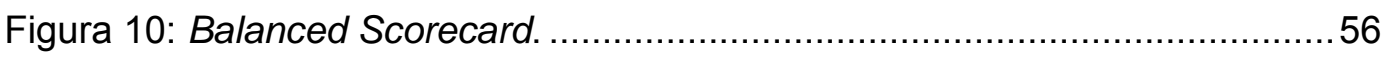

Figura 11: Organograma Empresa A...................................................... 72

Figura 12: Exemplo de fluxo de vendas da empresa A. .................................76

Figura 13: Organograma Empresa B (Matriz). ............................................. 84

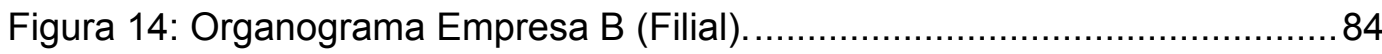

Figura 15 - Gráfico com as respostas de 2009 e 2015 do questionário de estilos de liderança - empresa A ................................................................ 91

Figura 16 - Gráfico com as respostas de 2009 e 2015 do questionário de estilos de liderança - empresa $B$

Figura 17 - Gráfico de comparação da pontuação dos estilos de liderança em 2009 e 2015/16 nas empresas A e B 


\section{Lista de tabelas}

Tabela 1. Integração dos Modelos de Ciclo de Vida 23

Tabela 2. Modelos de Ciclo de Vida $\quad 25$

Tabela 3: Estilos de liderança de White e Lippitt 34

Tabela 4: Significado das área do Grid Gerencial 35

Tabela 5: Características do líder transacional e transformacional 42

Tabela 6: As várias dimensões da liderança autêntica 44

Tabela 7: Modelo genérico para caracterização do desempenho

$\begin{array}{ll}\text { organizacional } & 48\end{array}$

Tabela 8: Visão parcial das contribuições e expectativas de

diversos Stakeholders 48

Tabela 9: Visão tradicional versus inovadora de medidores de desempenho 50

Tabela 10: Dimensões culturais e conteúdo $\quad 52$

Tabela 11: Empresas selecionadas para o estudo 60

Tabela 12: Afirmativas para classificação do estilo de liderança 61

Tabela 13: avaliação do desempenho da empresa pela percepção dos

tomadores de decisão $\quad 62$

Tabela 14: Características gerais da empresa A 67

Tabela 15: Missão da empresa A, na opinião do líder-fundador e seus funcionários para 2009 e 201570

Tabela 16: Visão da empresa A, na opinião do líder-fundador e seus

funcionários em 2009 e $2015 \quad 70$

Tabela 17: Valores da empresa A, na opinião do líder-fundador e

seus funcionários em 2009 e 2015

Tabela 18: Identificação das fases de diferenciação do ciclo de

$\begin{array}{ll}\text { vida organizacional - empresa A } & 78\end{array}$

Tabela 19 Características gerais - Empresa B $\quad 79$

Tabela 20: Missão da empresa B, na opinião do líder-fundador e de seus funcionários em 2009 e 2015

Tabela 21: Visão da empresa B, na opinião do líder-fundador e seus funcionários em 2099 e 2015

Tabela 22: Valores da empresa $B$, na opinião do líder-fundador e seus funcionários em 2009 e 2015 
Tabela 23: Identificação das fases de diferenciação do ciclo de vida organizacional - Empresa $B$

Tabela 24 - Frequência absoluta e \% coluna para avaliação da proporção de cada tipo de liderança nos anos de 2009 e 2015 em cada empresa analisada, seguido do p-valor teste exato de Fisher para comparação entre os anos de uma mesma empresa e para comparação entre as empresa em um mesmo ano

Tabela 25 - Média e desvio padrão do escore de liderança de cada empresa por ano, p-valor do teste Mann-Whitney para comparação entre anos de uma mesma empresa e entre empresas em um mesmo ano 92 Tabela 26: Informações Financeiras Adicionais das empresas A e B 97 Tabela 27: Médias finais dos indicadores de desempenho - Empresa A 99 Tabela 28: Médias finais dos indicadores de desempenho - Empresa B 99 Tabela 29: Evolução dos indicadores de desempenho entre 2009 e 2015 - Empresas A e B 


\section{1 \\ Introdução}

Centenas de pesquisas, livros e artigos tem sido escritos sobre liderança, um tema controverso abordado em diversas áreas de conhecimento. Conforme afirma Burns (1978) "liderança é um dos mais observados e menos compreendidos fenômenos da terra".

Entre as diferentes formas de abordagem do tema, é frequente sua associação ao processo de mudança e transformação das organizações (BASS, 1990), no qual são agregados ao líder atributos como visionário (SASHKIN, 1988; MINTZBERG e WESTLEY, 1992) e carismático (CONGER, 1989).

Este enfoque de liderança transformacional (CONGER \& KANUNGO, 1988; ROUCHE, BAKER, \& ROSE, 1989) tem priorizado aspectos intrapessoais (BENNIS \& NANUS, 1985) ou inter pessoais (BASS, 1990) do processo de mudança, isto é, como os líderes comunicam e desenvolvem uma visão (TICHY \& DEVANNA, 1986).

No entanto, cada vez mais as pesquisas têm constatado que fatores contextuais e estilos de liderança influenciam positivamente o desempenho organizacional (BASS \& AVOLIO, 1990; BRYMAN, 1992; LOWE, KROECK, \& SIVASUBRAMANIAM, 1996). A confirmação de que existe uma relação positiva entre o estilo de liderança e o desempenho organizacional não é uma unanimidade nos trabalhos do tema, mas a maioria das pesquisas enfatiza que líderes transformacionais, colaborativos e participativos são fundamentais para o sucesso de uma organização. (LOWE et al., 1996; PEDRAJA-REJAS, RODRIGUEZ-PONCE e RODRIGUEZ-PONCE, 2006).

Os líderes devem fornecer uma medida de estabilidade, mas ao mesmo tempo mantendo-se flexíveis, de tal forma que possam permitir a organização se adaptar a um mercado instável, diversificado, em rápida evolução tecnológica e global (BASS \& AVOLIO, 1990).

Das responsabilidades atribuídas a um líder, a tomada de decisão é uma das mais complexas e pode ter grande influencia ao negócio. O resultado de uma única decisão pode definir o curso e determinar o destino de uma organização. A tomada de decisão juntamente com a variedade de fatores contextuais (como a cultura corporativa, liderança, fatores ambientais internos e 
externos, governo, entidades reguladoras, entre outros), resulta em um número infinito de combinações únicas. O estilo do executivo na liderança também é um dos fatores que afeta a tomada de decisão (AVOLIO, 2007).

Cada líder tem um conjunto de características, experiências e conhecimentos exclusivos e idiossincráticos. O executivo tomador de decisão processa entradas ambientais por meio do seu filtro e estilo de liderança. Além das diferenças de perfis entre os líderes, certas características de liderança tornam-se mais eficazes e dominantes, dependendo da situação. (REIDER, 2011).

Combinadas três variáveis como: a situação, o estilo do líder, e a sua forma de expressão, é possível inferir que é pouco provável que qualquer líder individual esteja idealmente posicionado para maximizar o sucesso em todas as situações de tomada de decisão (CARVER, 1998; MALLAK, 1998).

Não reconhecer a influência do estilo de liderança sobre o processo de tomada de decisão pode ter como consequência levar a organização para uma direção contra producente. Para tanto, é preciso considerar adequadamente o papel que o estilo de liderança desempenha no processo de tomada de decisão para explicar, em parte, por que tantas decisões mal concebidas ou incorretamente executadas, resultam das mãos de líderes de sucesso comprovados de outra forma (REIDER, 2011).

Ao longo do tempo as empresas passam diversas mudanças e fases, exigindo diferentes decisões e diferentes perfis dos líderes, que variam segundo o ciclo de vida organizacional, que nos ajuda a entender as diferentes fases da evolução de uma organização.

Quando analisamos o papel do líder, há casos em que esse tema pode ser acentuado, como por exemplo, em pequenas empresas em que verificamos uma maior relação de influencia, não só pelo tamanho de sua estrutura organizacional, como pelo fase desenvolvimento da empresa, nível de profissionalização dos processos, dificuldade de uso de métodos e formalização na rotina.

O modelo do ciclo de vida é multifásico e descreve que as organizações progridem por meio de uma série de fases pré-definidas que seguem para frente, de uma maneira unidirecional e sequencial (GREINER, 1998). As fases individuais são descritas por um conjunto distinto de características, expectativas, resultados e desafios relacionados com o fenômeno a ser explorado. Esta exploração organizacional expõe as relações entre a organização e influenciam fatores ambientais, fornecendo um mapa das 
dinâmicas que ocorrem ao longo da existência de uma organização (JAWAHAR \& MCLAUGHLIN, 2001).

A dinâmica do mercado e o aumento das pressões ambientais, conduzem as empresas a um ponto em cada uma das fases do ciclo de vida, em que as exigências e as condições de mudança resultam em uma necessidade não atendida. Quando essa situação ocorre, as demandas do mercado não são mais satisfeitas e o desempenho da organização torna-se inadequado. $O$ déficit no desempenho organizacional cria um período de crise, exigindo que o líder tome uma decisão estratégica direcional (JAMES \& WOOTEN, 2005).

O tomador de decisão, ao mesmo tempo que é influenciado, seja pelo ambiente competitivo das corporações, pelo mercado, pela equipe, pela comunidade e por seus clientes, também influencia por meio de suas decisões (BASS \& AVOLIO, 1990).

Diante desta situação temos a seguinte questão que alimentará esta a pesquisa: Qual a influência do estilo de liderança no desempenho de uma empresa na fase de amadurecimento do ciclo de vida organizacional?

\section{1.}

\section{Objetivo final}

O objetivo final deste trabalho é analisar a influência do estilo de liderança, no desempenho de duas empresas de pequeno porte na fase de amadurecimento do seu ciclo de vida organizacional.

\section{2.}

\section{Objetivos intermediários}

Para se alcançar o objetivo final proposto neste estudo, foram delineados também os seguintes objetivos intermediários:

- Conceituar liderança, estilos de liderança e suas principais teorias; enfatizando as diferenças entre os estilos de liderança transacional e transformacional;

- Apresentar modelos de Ciclo de Vida das Organizações, de Indicadores de desempenho;

- Explicitar dentro dos modelos de ciclo de vida das organizações, o modelo de Greiner (1998), escolhido para a analise dos casos do estudo; 
- Apresentaras duas empresas cariocas escolhidas para a analise que foram estudas em 2009 numa dissertação anterior considerada como referencial para, analise 2015/16;

- Contextualizar e comparar os dados, dos anos de 2009 e 2015/16, sobre o estilo de liderança dos tomadores de decisão das duas empresas, especificamente comparar a influencia de estilos transacionais ou transformacionais no desempenho organizacional fase de amadurecimento do seu ciclo de vida organizacional.

\section{3.}

\section{Delimitação do estudo}

Teorias de liderança, desempenho e ciclo de vida são amplas e multifacetadas. Quando relacionamos estas questões com sua subjetividade a indicadores quantitativos e isolamos algumas variáveis organizacionais, podemos incorrer em distorções na análise.

O desempenho organizacional é fruto de inúmeras questões, muitas vezes associado a variáveis ambientais, o que dificulta a sua relação com decisões internas das organizações. Neste trabalho, buscamos isolar estas variáveis buscando com isto delimitar a nossa análise para alcançar o objetivo proposto.

Nesse estudo foi utilizada uma amostra selecionada de forma qualitativa, e não probabilística, para permitir a comparação de dados com a coleta de 2009, principalmente porque ela é significativamente relevante, no que diz respeito a priorizar os mesmos funcionários, envolvidos diretamente com os lideres das empresas pesquisadas, como foi feito na primeira aplicação dos questionários em 2009.

\section{4.}

\section{Relevância do estudo}

É um desafio e ao mesmo tempo uma questão fundamental a analise de estilos de liderança mais adequados para tomada de decisão organizacional. A contingencialidade deste processo tem sido fruto de inúmeros trabalhos e pesquisas, e a sua associação as diferentes fases do ciclo de vida organizacional, podem favorecer não apenas o estudo do tema, como instrumentalizar decisores que precisam planejar o futuro organizacional.

Esta é a relevância deste trabalho, associar duas bibliografias complexas e ricas de variações para aprofundar um tema fundamental no cotidiano organizacional. 


\section{2 \\ Referencial teórico}

O foco desta pesquisa é analisar a influencia do estilo de liderança nas decisões tomadas durante o ciclo de vida de uma organização. Para essa análise foram considerados três componentes relacionados e de significativa influência: (a) os ciclos de vida organizacional, (b) as características liderança que os tomadores de decisão possuem e expressam, e (c) indicadores de desempenho.

Nesse estudo foi adotada uma visão pragmática da literatura, utilizando as partes relevantes de cada área, para permitir uma análise do papel das características de liderança durante a fase de amadurecimento do ciclo de vida organizacional, pois sem levar em consideração as características de liderança e a sua influência, a decisão do líder seria menos previsível e o resultado poderia ser menos satisfatório para a organização ao longo do tempo.

O conceito de ciclo de vida foi inicialmente emprestado dos campos das ciências sociais e naturais (O'RAND \& KRECKER, 1990); em seguida, foi aplicado para organizações. Essas adaptações permitiram a exploração de fenômenos de gestão (por exemplo, estilo de liderança, inovação de produtos e desenvolvimento de sistemas). Independentemente dos fatores selecionados, o modelo de ciclo de vida organizacional permite ao pesquisador considerar as interações e relações entre os fatores, bem como o efeito de mudanças nos fatores individuais ao longo do tempo (MINTZBERG e WESTLEY, 1992; QUINN e CAMERON, 1983).

Os pontos que caracterizam as fases de ciclo de vida que são de interesse neste estudo são:

- o foco;

- o período de tempo;

- a estrutura organizacional;

- o processo de tomada de decisão;

- a utilização de sistemas; e

- o estilo e tipo de comunicação. 
Similar as áreas de estudos sobre ciclos de vida organizacionais e os indicadores de desempenho, a literatura sobre liderança é ampla e variada. Uma ampla gama de teorias foram desenvolvidas, para descrever e interpretar comportamentos de um líder, suas interações e reações na tomada de decisão por meio de variáveis e circunstâncias específicas.

Das muitas teorias de liderança disponíveis, as teorias transacionais e transformacionais são baseadas no contexto comportamental. Essas duas teorias são idealmente posicionadas, no que diz respeito a descrever mudanças na perspectiva de liderança, decisões, ações e relações com os liderados ao longo do tempo. Ao combinar as características de liderança descritas nestas duas teorias, os atributos de liderança resultantes mais constantes podem ser sobrepostos no modelo do ciclo de vida organizacional.

Nessa pesquisa foi analisada a relação entre as fases do ciclo de vida organizacional e o estilo de liderança. Para tal, a pesquisa examinou a literatura que envolve os três campos de estudo mencionados acima e, em seguida, foi analisada a interface e a relação entre os fatores relevantes a partir desses campos.

\section{1.}

\section{A utilidade dos ciclos de vida de organizacionais}

A ciência social do ciclos de vida trata dos processos geracionais, de amadurecimento ou desenvolvimento, que podem ser definidos em fases discretas (O'RAND \& KRECKER, 1990). Os modelos de ciclos de vida organizacionais utilizam premissas semelhantes, características especificamente identificáveis e previsibilidades comportamentais que estão associadas ao crescimento e desenvolvimento de uma organização ao longo do tempo (CAMERON e WHETTEN, 1981; QUINN e CAMERON, 1983).

Frequentemente, os ciclos de vida são descritos de forma unidirecional, com três ou quatro fases e com processos sequenciais. A natureza flexível e adaptável do modelo de ciclo de vida tem proporcionado aos estudiosos uma estrutura pragmática sobre como explorar a evolução, as decisões, as estratégias e a estrutura de uma organização. O processo de exploração revela a relação entre os fatores de influência, fornecendo um mapa das dinâmicas que ocorrem ao longo da vida de uma organização (JAWAHAR \& MCLAUGHLIN, 2001; KIMBERLY \& MILES, 1980; MINTZBERG e WESTLEY, 1992), além de permitir a descrição das mudanças organizacionais (QUINN \& CAMERON, 1983). 
As fases de um ciclo de vida são definidas e distinguidas analisando as características específicas do comportamento. Cada uma das múltiplas fases tem objetivos e foco específicos, que mudam, mas tendem a ter um padrão reconhecível ao longo do tempo. Como a organização se move de uma fase à outra, o foco, estratégias, estrutura e necessidades gerenciais também evoluem.

Historicamente, Haire (1959) e Downs (1967) foram os primeiros a aplicar modelos faseados do ciclo de vida para as organizações. Eles segmentaram as características organizacionais, indicadores e recursos descritivos em fases distintas ao longo do tempo (SMITH et al., 1985). Quinn e Cameron (1983) observaram que as fases do ciclo de vida são sequenciais por natureza,a progressão não é facilmente revertida, e envolvem uma ampla gama de características organizacionais, atividades, estruturas e comportamentos.

Muitos modelos compartilham características comuns (QUINN e CAMERON, 1983; SMITH et al., 1985), sendo os fatores organizacionais e os ambientais capazes de descrever e medir o período de tempo.As fases são mapeadas como uma trajetória ao longo de um período que representa a vida do organismo. É a mudança nas características ao longo do tempo que permite a distinção entre as fases do ciclo de vida.

O movimento entre as fases ocorre por causa da presença de um acontecimento que provoca uma inflexão no caminho do ciclo de vida (GREINER, 1998). O evento representa a influência de fatores ambientais sobre a organização (DODGE, FULLERTON \& ROBBINS, 1994). Em conjunto, a descrição das fases e os eventos que provocam a mudança no caminho do ciclo de vida constituem um modelo específico.

\section{2.}

\section{Modelos de ciclo de vida organizacional e as características das fases}

Independentemente da segmentação, os modelos do ciclo de vida organizacional definem as fases de acordo com um foco principal ou objetivo. Por exemplo, a fase inicial de um modelo com foco no produto pode incorporar características que definem inovação de produtos e a descoberta de soluções para atender as exigências do mercado. Em seguida a organização para fase de reprodutibilidade e produção em escala para atender a demanda do mercado. Depois segue para uma fase à procura de maiores lucros, impondo estruturas de custos, negociações colaborativas com fornecedores e economias de escala. Finalmente, torna-se o objetivo a manutenção das margens com reduções de custos. 
Outro exemplo, é o modelo de ciclo de vida de Steinmetz (1969), focado em padrões de receita organizacionais, permitindo o exame de fatores que afetam ou mudam a receita. O modelo de Steinmetz segue a tradicional curva de crescimento em $S$ em que a receita (variável independente) é representada graficamente ao longo do tempo e dividida em três fases que se distinguem pela mudança na sua inclinação. As três fases são, start-up, crescimento e maturidade.

A fase de start-up permanece inicialmente plana na introdução no mercado e enquanto na aceitação do produto, ocorrendo um ponto de inflexão, momento em que ele atinge a aceitação do mercado e tem o crescimento rápido. A receita ao longo do tempo se mantem e durante a fase de crescimento tem um declive mais acentuado até que algum evento ambiental, por exemplo, o aumento da concorrência, ou a introdução de nova tecnologia, muda o caminho de ciclo de vida. Nesse momento, a taxa de crescimento diminui e a fase de maturidade começa, sendo caracterizada por um achatamento da taxa de receita, que eventualmente resulta em uma erosão da fatia de mercado e o declínio organizacional.

Os modelos de ciclo de vida também frequentemente incorporam algum tipo de componente estrutural. A evolução da estrutura ajuda identificar rompimentos ao longo do tempo. As estruturas mais populares incluem as características, como:informal para o formal, centralizado para descentralizado e de plano para hierárquico ou matricial (GREINER, 1998; MINTZBERG e WESTLEY, 1992).

Scott (1971) propôs um modelo focado nos contrastes de estrutura com as mudanças nas estratégias de produto e recompensa. Uma estrutura plana e informal, com foco em um único produto evolui para uma hierarquia funcional e especializada impulsionada pela diversificação e expansão e adaptação da linha de produtos.

Como a estrutura, os indivíduos dentro da organização se desenvolvem ao longo do tempo. Os modelos de Torbert (1974) e Adizes (1979) descrevem a evolução do foco do indivíduo ao longo do tempo. Torbert (1974) propôs um modelo no qual o indivíduo se torna mais experiente e seu conhecimento se amplia, desenvolvendo um maior grau de eficácia. Torbert coloca que os indivíduos se movem da individualidade e informalidade na fase inicial para unidade de grupo, e eventualmente, do trabalho num formato com estrutura e regras, para a habilidade de se adaptar e renovar. 
Num modelo de quatro fases, Adizes (1979) descreveu o indivíduo evoluindo em paralelo as atividades de organização: Fase 1 é empresarial e desenvolvimento; Fase 2 é a formalização e integração; Fase 3 é a maturidade, e Fase 4 é o respeito e estabilidade. O mecanismo de mudança é o resultado de superaçãodos problemas que surgem dentro de uma fase.

Alguns estudiosos adaptaram o modelo humano do ciclo de vida para descrever mudanças na estrutura organizacional. Downs (1967) no modelo de crescimento e desenvolvimento, e o modelo focado em gestão de Lippitt e Schmidt (1967), aplicado em produto (ou seja, inovação, criatividade e diferenciação) e no desenvolvimento de mercado com um modelo de três fases refletindo o nascimento, a juventude e maturidade.

Miller e Friesen (1980) continuaram no tema ciclo humano e ampliaram suas características para incluir também a supervisão. Eles propuseram um modelo sequencial semelhante ao de quatro fases que consiste em fases distintas mas que se sobrepõem, definidas como start-up (nascimento), emergente (crescimento), maturidade e renascimento.

Mintzberg (1973; MINTZBERG e WESTLEY, 1992), considerou a tomada de decisão para estruturar o desenvolvimento do individual para o grupo, do técnico para orientação por processo, do ofício ao profissional, e do julgamento para orientação por fatos na tomada de decisão.

Nas fases iniciais, quando a estrutura é plana e a comunicação informal, o líder técnico ou fundador toma as decisões de forma unilateral. Durante as fases intermediárias, a tomada de decisões é descentralizada e empurrada para baixo em função de uma gestão funcional e de especialistas técnicos. Posteriormente, as fases realizam um movimento circular e voltam incluindo um processo de tomada de decisão formal e ainda mais centralizado.

Semelhante a tomada de decisão, sistemas organizacionais evoluem de produção básica e cooperação geral dos indivíduos para concentração em uma coordenação estruturada e o controle do comportamento, levando à necessidade de mecanismos de adaptação em função da influência do ambiente externo. $O$ modelo estrutural de Kimberly e Miles (1980) de quatro fases se desenvolve com as seguintes etapas: (a) formação de uma idéia juntamente os fundadores e pessoal de apoio; (b) estabelecimento uma entidade corporativa tangível; (c) a criação de uma identidade organizacional com a definição de uma estrutura para pessoas, papéis, metas e compromissos; e, finalmente, (d) estruturalmente diferenciada, institucionalizada formalizada e suportando à influência do ambiente externo. 
O desenvolvimento e uso de sistemas são próximos e ocorrem em paralelo a maturidade da estrutura organizacional e se relacionam com o estilo e tipo de comunicação. Scott (1971) e Greiner (1998) descreveram algo similar para o processo de comunicação, com parâmetros que vão do informal para o formal, de instruções verbais para instruções escritas, de nenhuma documentação a documentação detalhada, de instruções centralizadas para descentralizadas, de uma aplicação local para global, de baixa aderência à alta aderência.

Reconhecimento e recompensa é um dos muitos sistemas de gestão que mudam à medida que a empresa evolui. Ele está intimamente ligado às mudanças nas medidas de desempenho e foco organizacional. A descrição de recompensa inclui características de subjetiva a objetivas, de pessoais a impessoais ou de grupo, espontâneas a previsível, de diretamente para indiretamente ligados ao desempenho, e de informal para o formal (GALBRAITH, 1982a, 1982b; SCOTT, 1971).

Mudanças no tipo de gestão e no estilo de comunicação foram mapeados de forma independente e em combinação com outros fatores. O modelo de gestão de três fase de Lippitt e Schmidt (1967) inclui a criação e sobrevivência, a estabilidade interna e ganho de reputação e a maturidade com a caracterização do foco externo.

Da mesma forma, Steinmetz (1969) baseou seu modelo de ciclo de vida de quatro fases em mudanças no comportamento de supervisão: (a) a supervisão direta, (b) supervisionando a supervisão, (c) o controle indireto, e (d) a divisão da organização. Foi descrito por ele, que as necessidades de supervisão mudam à medida que a organização tem aumentos na receita e no número de empregados. O modelo de Steinmetz é espelhado nos quatro estágios da Teoria da Liderança Situacional de Blanchard: delegação, apoio, orientação e direção.

O modelo mapeado por Greiner (1998) de estilo de gestão muda o foco inicial e começa com a gestão individual e foco empresarial, para um estilo diretivo e de operações eficientes, passando para delegação durante a expansão do mercado e terminando com gestão participativa para promover a resolução de problemas.

O tipo de comunicação e estilo normalmente se alteram sincronizados com a gestão e desenvolvimento de sistemas (ou seja, a especialização e a diferenciação) e os processos de tomada de decisão. Vários escritores descrevem as etapas de comunicação de subjetiva para objetiva, de informal para formal, de verbal para escrita, de local para corporativa, de cara-a-cara para a distância; e de unilateral à colaborativa (GREINER, 1998; SCOTT, 1971). 
Muitos modelos de ciclo de vida se concentram na inovação e diferenciação de produto. Um exemplo de um ciclo de vida que privilegia o produto é modelo de quatro fases de Lyden (1975), que tem como base a mudança de requisitos funcionais. $O$ foco principal da Fase 1 está na criação de presença de mercado e inovação. Durante a Fase 2, a organização é focada em processos de fluxo de trabalho, enquanto que a Fase 3 , foi ressaltada a necessidade de eficiência e eficácia desses processos e da produção. Na Fase 4 destaca-se a institucionalização de processos, manutenção e estrutura.

Com base em características de nove modelos Quinn e Cameron, (1983), elaboraram um sumário dos modelos de ciclo de vida em quatro etapas: empreendedorismo, coletividade, formalização e controle, e elaboração da estrutura. Esse sumário é apresentado na Tabela 1 a seguir:

Tabela 1. Integração dos Modelos de Ciclo de Vida

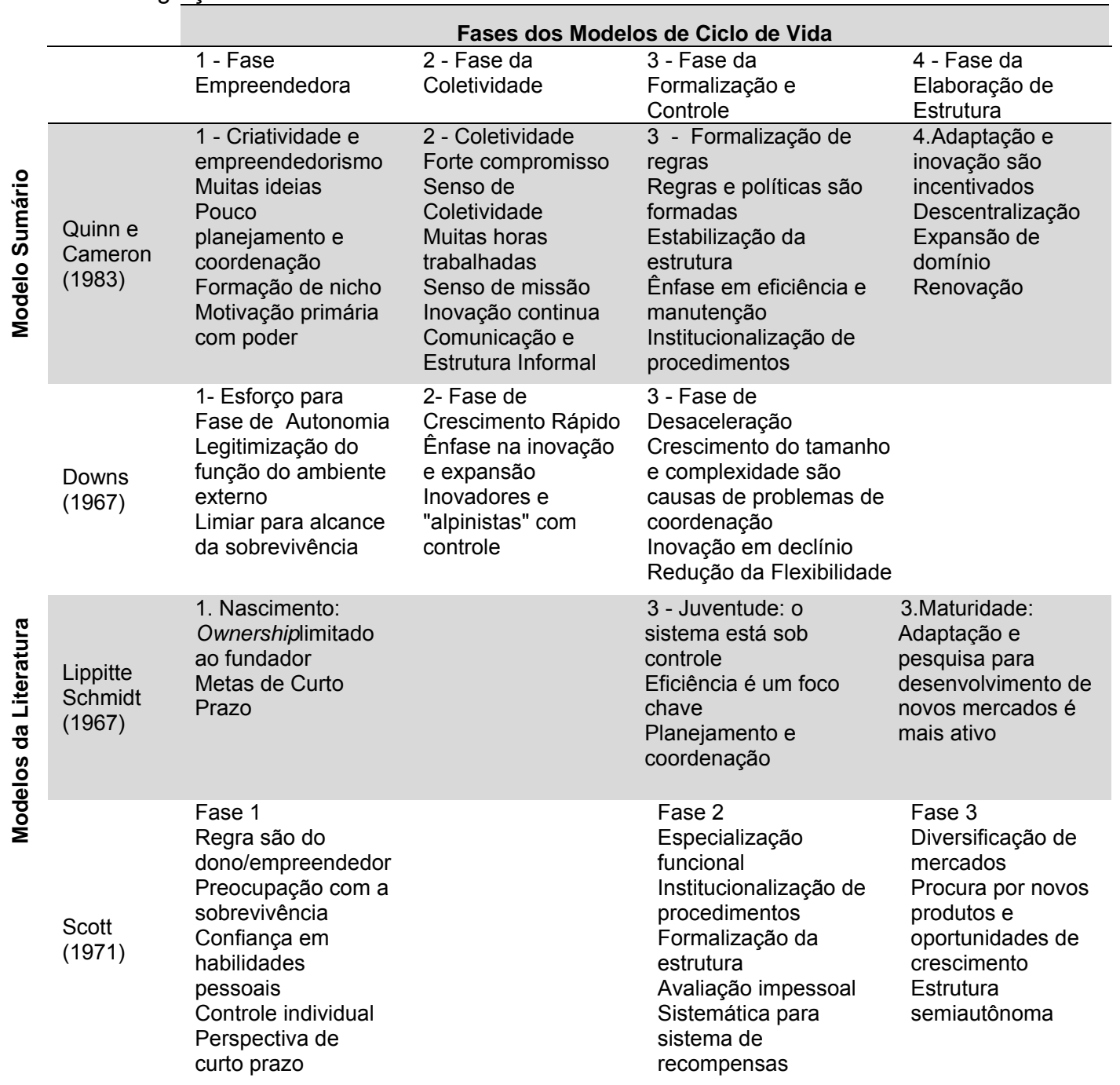




\begin{tabular}{|c|c|c|c|c|}
\hline $\begin{array}{l}\text { Torbert } \\
\text { (1974) }\end{array}$ & $\begin{array}{l}\text { 1- Fase da Fantasia } \\
\text { - percepção difusa } \\
\text { dos membros } \\
\text { visões individuais e } \\
\text { fantasias }\end{array}$ & $\begin{array}{l}2 \text { - Fase do } \\
\text { Investimento - alto } \\
\text { investimento } \\
\text { individual } \\
3 \text { - Fase da } \\
\text { Determinação - } \\
\text { contratos } \\
\text { psicológico, grupos e } \\
\text { estruturas são } \\
\text { estabelecidos }\end{array}$ & $\begin{array}{l}\text { 4- Fase de } \\
\text { Experimentos - regras, } \\
\text { governança, } \\
\text { responsabilidades são } \\
\text { estabelecidos } \\
5 \text { - Fase da } \\
\text { Produtividade Pré- } \\
\text { determinada - foco na } \\
\text { performance das } \\
\text { tarefas }\end{array}$ & $\begin{array}{l}6 \text { - Fase da } \\
\text { Estrutura } \\
\text { Abertamente } \\
\text { Escolhida - } \\
\text { colaboração entre } \\
\text { os níveis } \\
7 \text { - Fase da } \\
\text { Comunidade } \\
\text { Fundacional - } \\
\text { organização se } \\
\text { torna uma } \\
\text { comunidade } \\
8 \text { - Fase das } \\
\text { Disciplinas } \\
\text { Libertadoras -foco } \\
\text { na renovação e } \\
\text { procura de } \\
\text { desafios }\end{array}$ \\
\hline $\begin{array}{l}\text { Lyden } \\
\text { (1975) }\end{array}$ & $\begin{array}{l}1 \text { - Primeira Fase - } \\
\text { ênfase na } \\
\text { adaptação ao } \\
\text { ambiente externo } \\
\text { 2- Segunda Fase - } \\
\text { ênfase na aquisição } \\
\text { de recursos }\end{array}$ & & $\begin{array}{l}\text { 3- Terceira Fase - } \\
\text { ênfase no alcance de } \\
\text { objetivos } \\
4 \text { - Quarta Fase - } \\
\text { ênfase na manutenção } \\
\text { do padrão e } \\
\text { institucionalização }\end{array}$ & \\
\hline $\begin{array}{l}\text { Adizes } \\
\text { (1979) }\end{array}$ & $\begin{array}{l}\text { 1.Namoro } \\
\text { Atividades } \\
\text { empreendedoras } \\
\text { Fundadores se } \\
\text { questionam "o que } \\
\text { poderíamos fazer? }\end{array}$ & $\begin{array}{l}2 \text { - Organização } \\
\text { Infantil } \\
3 \text { - Fase"Go-Go"da } \\
\text { organização } \\
\text { (expansão e tomada } \\
\text { de decisão rápidas) }\end{array}$ & $\begin{array}{l}\text { 4- Organização } \\
\text { Adolescente } \\
5 \text { - Organização } \\
\text { "Prime" (ênfase na } \\
\text { eficiência) } \\
\text { 6- Organização } \\
\text { Madura } \\
7 \text { - Organização } \\
\text { Aristocrata } \\
8 \text { - Inicio da Burocracia } \\
9 \text { - Burocracia } \\
10 \text { - Morte }\end{array}$ & \\
\hline $\begin{array}{l}\text { Kimberly } \\
\text { (1979) }\end{array}$ & $\begin{array}{l}\text { 1- Primeira Fase } \\
\text { Organização de } \\
\text { recursos } \\
\text { Criação de uma } \\
\text { ideologia }\end{array}$ & $\begin{array}{l}2 \text { - Segunda Fase } \\
\text { Obtenção de suporte } \\
\text { para atuação junto } \\
\text { ao ambiente externo } \\
\text { Estruturação da } \\
\text { equipe } \\
\text { 3- Terceira Fase } \\
\text { Formação de } \\
\text { identidade } \\
\text { Senso de } \\
\text { coletividade }\end{array}$ & $\begin{array}{l}\text { 4- Quarta Fase } \\
\text { Formalização da } \\
\text { estrutura e regras } \\
\text { Competição interna } \\
\text { Conservadorismo }\end{array}$ & \\
\hline $\begin{array}{l}\text { Greiner } \\
\text { (1998) }\end{array}$ & $\begin{array}{l}\text { 1- Fase da } \\
\text { Criatividade }\end{array}$ & & $\begin{array}{l}\text { 2.Fase do } \\
\text { Direcionamento } \\
\text { 3.Fase da Delegação } \\
\text { 4.Fase da } \\
\text { Coordenação }\end{array}$ & $\begin{array}{l}\text { 5.Fase da } \\
\text { Colaboração }\end{array}$ \\
\hline
\end{tabular}

Fonte: Adaptado do Modelos Modelo sumário de Ciclo de Vida de Quatro Fases de Quinn e Cameron (1983, p. 34-40)

O tamanho da empresa e sua idade são utilizados direta e indiretamente na literatura como uma característica do ciclo de vida. As caracterizadas de uma organização em start-up, jovem e pequena versus uma que é caracterizada como madura, mais velha e maior são sugeridas e especificamente declaradas por algumas literaturas como um diferencial de fase (SMITH et al., 1985). 
Posteriormente, é entendido que a relação entre o tamanho, idade e fase do ciclo de vida já não se correlacionam tão fortemente como antes. Isto é em parte resultado das rápidas mudanças na tecnologia e maior sofisticação com a comunicação informatizada. As organizações são forçadas a evoluir rapidamente e alcançar um grande sucesso, fracassando em períodos muito curtos. Embora estas organizações progridam por meio das fases do ciclo de vida, isso é realizado com tal velocidade que a maturidade organizacional como é definida tradicionalmente nunca é alcançada.

A partir do identificação dos modelos clássicos na literatura sobre Ciclo de Vida Organizacional, também foram identificadas as contribuições de autores mais recentes compilados na Tabela 2 , a seguir:

Tabela 2. Modelos de Ciclo de Vida

Autores

Miller e Friesen (1984)

Kazanjian e Drazin (1990)

Baker e Cullen (1993)

Moores e Yuen (2001)

Granlund e Taipaleenmäki (2005)

Auzair e LangfieldSmith (2005)

Lester, Parnell e Carraher (2003)

\section{Contribuições}

A aplicação de testes empíricos para os elementos que constituem a diferenciação dos ciclos de vida: estratégia, estrutura, ambiente, e processo decisório. Os estudos empíricos mostraram complementaridade entre os elementos.

Modelo com quatro estágios, sob uma visão contingencial: concepção e desenvolvimento, comercialização, crescimento e estabilidade. Levaram em conta para especificar os estágios: (i) o processo decisório: centralizado ou formalizado; (ii) especialização funcional: marketing / vendas, manufatura, tecnologia/ engenharia; e (iii) taxa de crescimento: acima ou abaixo de referencial.

Uso de variáveis relevantes como: idade, tamanho e mudança de tamanho. Focalizam os extremos, ou seja, de um lado as empresas jovens, pequenas e em crescimento, que devem ter níveis de reorganização mais altos do que as empresas mais velhas, grandes e em declínio (1993, p.1252).

Consideram quatro variáveis que são: estratégia, estrutura, liderança e estilo de processo decisório. Utilizaram variáveis externas para testar o modelo: idade, crescimento das vendas e indicador ponderado de performance. Aplicaram o teste Kruskal-Wallis para essa base de dados, o que se revelou adequado.

Questionam a abordagem de Miller e Friesen (1984) referente ao ciclo de vida das empresas, particularmente aquelas ligadas à Nova Economia. Adotam a abordagem de Victor e Boynton (1998), ao considerar os estágios de artesanato, produção em massa, aperfeiçoamento de processos, customização em massa e co-configuração/renovação.

Uso da abordagem de Miller e Friesen (1984), entretanto com três estágios: formação, crescimento e maturidade (p.404). Sugerem dois lados do continuum: de um lado mais burocrático-ação e outro informal, flexível com controles interpessoais. Caracterização da diferenciação na estratégia, utilizando a tipologia de Porter (1980), que separa a estratégia em diferenciação e liderança de custo. Inferem, a partir de Kumar e Subramaniam (1997), que a estratégia de diferenciação põe foco na criatividade e no controle de resultados.

Modelo de cinco estágios com quatro variáveis principais: tamanho da empresa, estrutura organizacional, processamento de informações e tomada de decisão. Os estágios são: nascimento, crescimento, amadurecimento, rejuvenescimento e declínio.

Fonte: Adaptado de Frezatti et al., p. 5. 2009. 


\section{3.}

\section{A aplicação do modelo de ciclo de vida usando a cinco fases do ciclo de vida como diferenciais}

Aplicabilidade do modelo de ciclo de vida, como uma ferramenta para examinar uma variedade de fatores de negócios é usual na literatura de gestão. Um dos pontos fortes desta ferramenta é que ela não só possibilita que fatores singulares sejam mapeados ao longo do tempo, mas também permite o exame das relações entre os fatores mapeados e o efeito de influências externas.

Uma dinâmica previsível ocorre dentro de cada fase, e eventualmente, mudanças no ambiente externo podem tornar uma circunstância insatisfatória, criando um ponto de crise. Por exemplo, durante a fase 1 , se o cliente gostar da solução desenvolvida, a empresa pode ser demandada a fornecer mais produtos do que a capacidade de produção. Da mesma forma, durante a Fase 4 a competição pode oferecer novas tecnologias, causando uma mudança nas expectativas e necessidades dos clientes. As circunstâncias podem ter diferentes formas, mas um ponto de crise irá ocorrer em algum momento durante cada fase do ciclo de vida.

Quando a crise ocorre, a gestão é confrontada com a decisão de aceitar as circunstâncias atuais com a possibilidade de queda e extinção ou fazer uma mudança permitindo a organização passar para a próxima fase.

No modelo de ciclo de vida proposto por Greiner (1998), ficam representadas essas crises em cada uma das cinco fases. O crescimento das organizações se identifica pelas seguintes etapas:

- Criatividade, com estrutura informal, mas que entra em crise de direção;

- Direção, com estrutura funcional, e que entra em crise de autonomia;

- Delegação, com estrutura divisional, e entra em crise de controle;

- Coordenação, mantém a estrutura divisional, com maior controle e coordenação, e uma crise de burocracia;

- Colaboração, com estrutura matricial, e pode entrar em crise de "saturação psicológica" ou de "esquizofrenia organizacional".

Na Figura 1, seguir a representação do modelo do ciclo de vida das organizações de Greiner. 


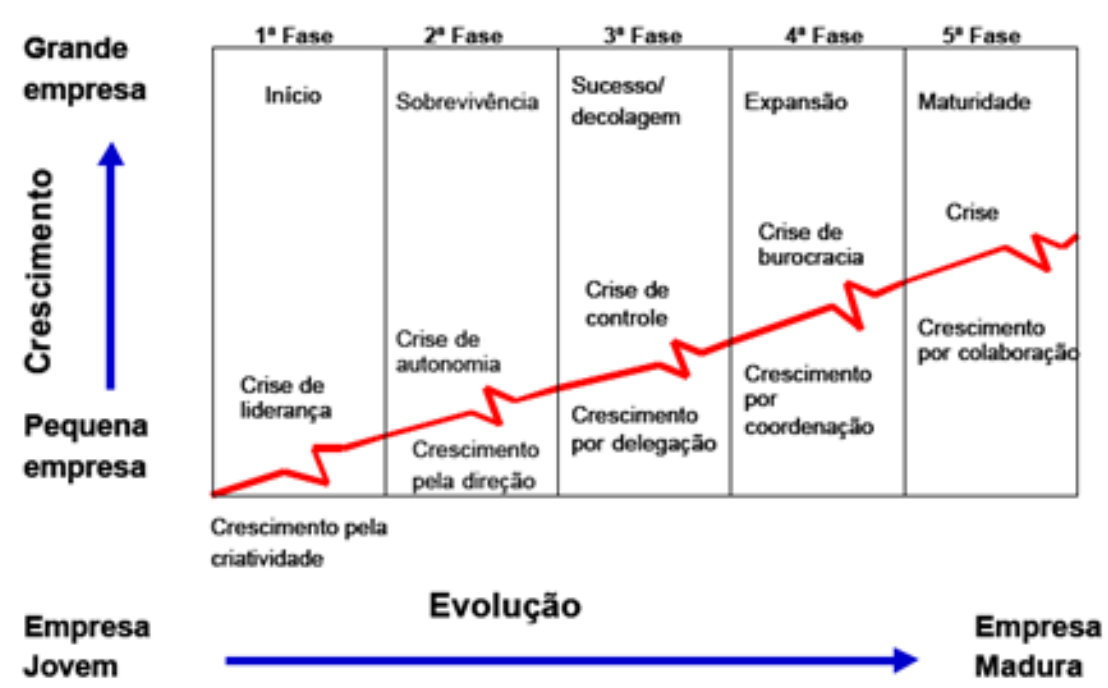

Figura 1: Modelo de ciclo de vida organizacional

Fonte: Adaptado de Greiner (1998, p. 58)

\section{4.}

\section{As fases do ciclo, suas demanda e as necessidades do mercado}

Todas as organizações tem o objetivo de preencher uma necessidade do mercado. O casamento da necessidade do mercado e solução resultada de uma descoberta começa com a inovação. Essa união de atendimento da necessidade do mercado e inovação inicia um ciclo de vida organizacional. É a gênese de uma organização que direciona processos e práticas iniciais que giram em torno do desenvolvimento de uma solução para o mercado.

\subsection{1.}

\section{Fase 1: criar (Start-up)}

A Fase de Start-up engloba o desenvolvimento da solução, do mercado, e da infraestrutura. Nessa fase os fundadores são primeiramente orientados à produtos e de forma secundária organizacionalmente (GREINER, 1998). O futuro da empresa depende da transformação com sucesso dos conceitos técnicos em uma solução comercialmente viável.

A comunicação entre fundadores e empregados é informal, verbal, e frequente. $\mathrm{O}$ ambiente é intimista, com pequeno número de funcionários e com tomada de decisão imediata (SCHEIN, 2004). As organizações têm poucas orientações formais, escritas e raros ou nenhum sistema para seguir (GREINER, 1998). A tomada de decisão é centralizada e a entrada de uma equipe é feita de acordo com a demanda pelos fundadores, e por alguns líderes técnicos (BAZERMAN, 2006). Além de se concentrar no desenvolvimento de um produto comercialmente viável, a liderança também concentra-se no essencial para conseguir que a organização funcione. 
O primeiro ponto de crise resulta da organização buscar ter capacidade para resposta à demanda crescente de clientes por produtos. O líder empreendedor, tão valorizado pela inovação e soluções de desenvolvimento, pode não ter a profundidade e amplitude de habilidades para negócios e saber como movimentar a organização através de todas as etapas para preencher adequadamente as exigências do mercado. Um novo tipo de liderança com habilidades em negócios, operação e marketing é necessário para mover a organização para a próxima fase (GREINER, 1998).

\subsection{2.}

\section{Fase 2: direção (crescimento)}

Garantias de crescimento na Fase 2 são sustentadas por meio do desenvolvimento do mercado, de uma organização funcional e hierárquica, e com sistemas operacionais. Para canalizar a energia empreendedora em crescimento, os líderes de nível mais baixo são tratados como especialistas, a tomada de decisão e a comunicação tornam-se formais e centralizadas, e eficiências operacionais começam a ser alcançadas. A equipe cresce em números, com papéis e responsabilidades e começa ter mudanças na estrutura de plana para hierárquica (GREINER, 1998).

A Fase 2 tem efeitos não apenas sobre os aspectos práticos da organização, mas também sobre a cultura corporativa. Schein (2004) destacou que, a medida que uma organização evolui, as crenças e normas técnicas que os fundadores estabeleceram tornam-se histórias, permitindo a mudança para um novo conjunto de valores e comportamentos.

Algumas das normas originais tornam-se impraticáveis e incompatíveis com os comportamentos e práticas necessárias para abastecer o mercado com seu produto de forma confiável, sendo a revisão necessária para permitir que a organização continue a prosperar.

A crise dessa etapa é resultado da necessidade de se obter eficiências de produção e redução do custo dos produtos. Para continuar a penetrar no mercado, os clientes exigem melhores preços e começam a olhar para a próxima geração de produtos. Devem ter destaque a diferenciação de papéis e autonomia na tomada de decisão. O papel e as responsabilidades da liderança devem passar por uma metamorfose, confiando-se mais em sistemas e processos como a base para a tomada de decisões, e permitindo que os funcionários de níveis inferiores tenham mais autonomia. 


\subsection{3.}

\section{Fase 3: delegação (amadurecimento)}

A Fase 3 é marcada pela continuidade da expansão da capacidade e a necessidade de desenvolvimento de eficiências em custos e em processos. A aquisição ou a criação de uma capacidade de produção em escala comercial e a contratação de gerentes operacionais experientes oriundos de grandes corporações, trazem uma mudança esperada na cultura, especialmente nas linhas de produção remotas e locais (SCHEIN, 2004).

A tomada de decisão é descentralizada para a liderança funcional e para os lideres de produção. Aumenta a formalidade na comunicação. Orientações gerais são fornecidas pelo corporativo, deixando os locais remotos interpretarem e implementarem essas orientações de uma forma independente.

A diferenciação dos papéis continua, com a liderança da corporação concentrando-se em gestão do ambiente externo, principalmente com investidores e clientes. Existe uma bifurcação continua em um número crescente com pequenas áreas de tendências a resistência, por meio da qual a "velha guarda" cria zonas de histeria (CARVER, 1998). A retirada desses indivíduos incompatíveis e que preferem permanecer no ambiente empreendedor e centralizado, misturado a entrada de resultados do "sangue novo" é a segunda mudança significativa na cultura corporativa (SCHEIN, 2004).

Durante a Fase 3, a concorrência entra no mercado de uma forma significativa. O crescimento do mercado começa a diminuir, colocando pressão adicional e atenção as melhorias nas finanças. Como a crise cresce, a luta pelo controle (GREINER, 1998) inflama e o desconforto dos executivos corporativos em delegar controle aumenta e atinge um pico. Esta fase é um teste para liderança que deve ser visionária e demonstrar capacidade para deixar o passado de lado e ver o futuro.

\subsection{4.}

\section{Fase 4: coordenar (sustentação)}

Nesta fase, em geral, a confiança e comunicação ficam corroídas, conforme a empresa se distancia de suas raízes empreendedoras e se movimenta para a descentralização das unidades funcionais, com a centralização de unidades de apoio, o uso de sistemas formais de coordenação e controle, o aumento do controle por meio de processos de comunicação, e com o foco no cliente e investidor externo (GREINER, 1998; SCHEIN, 2004). 
O desenvolvimento de sistemas continua, relatórios e aumento do controle, e a confiança mútua entre a sede e os locais remotos diminui apesar do esforço da sede em aumentar a comunicação. As expectativas de desempenho estão passando do âmbito empresarial em geral para incentivos pessoais e de grupo, garantindo que os objetivos individuais estejam vinculados às metas corporativas. A maioria resiste ao nível de burocracia e de institucionalização dos sistemas, declarando que há uma demasiada e desnecessária burocracia (GREINER, 1998).

O desenvolvimento de sistemas traz consistência, permite níveis inferiores na estrutura a tomar decisões com menos insumos. No entanto, a institucionalização de sistemas reduz o pensamento crítico, inovador e a tolerância a incertezas, sendo ambos necessários para criação de um ambiente de resiliência (MALLAK, 1998).

A concorrência continua a diminuir as fatias de mercado com ofertas de preços mais baixos, melhores produtos e soluções com novas tecnologias. A pressão competitiva desloca a expectativa do cliente, e resulta em uma diminuição acelerada de vendas. Com a crise da Fase 4 a organização deve refletir se vai continuar com seu produto maduro para o seu fim natural ou vai encontrar uma maneira de se reinventar.

Aqueles que estavam previamente adaptados e favoráveis ficaram sensibilizados e perderam a sua confiança (CARVER, 1998). Como resultado, leva mais tempo do que o esperado para voltar ao ponto zero após uma adversidade, e ainda mais tempo para crescer e prosperar (CARVER, 1998).

\subsection{5.}

\section{Fase 5: declínio ou reinventar}

O final de um ciclo de vida não significa necessariamente o fim da corporação. Será necessário recuperar a agilidade anterior com menos burocracia, processos simplificados, transparência na informação, pronto acesso a dados para a tomada de decisão rápida e,para que uma visão de longo prazo seja difundida na organização em um período colaborativo.

Carver (1998) propôs que, para se deslocar do declínio de volta à prosperidade, o foco corporativo deve mudar em quatro aspectos importantes: (a) de operações para o cliente; (b) não usar receita apenas e ir para o lucro por ação; (c) a partir de um curto prazo, com único mercado para um longo prazo, para uma abordagem de múltiplos mercados; e (d) de sistemas isolados para colaborativos e multifuncionais. 
Nessa fase o desafio da liderança envolve fomentar e destacar a inovação em uma estrutura madura. Em paralelo, a evolução dos sistemas formais e burocráticos com um modelo tomada de decisão rápido de solução de problemas trabalham para apoiar o seu lado inovador. Reconhecer a necessidade de envolver dois conjuntos de características de liderança é crítico. A liderança individual e os colaboradores devem decidir se eles permanecerão não adaptados, ou se irão lidar com a crise se tornando resilientes e bem-sucedidos (CARVER,1998).

\section{5 . \\ O papel das características de liderança em um modelo de ciclo de vida}

De acordo com Bass (1997) a liderança é um fenômeno universal. Nenhum grupo de social ou de negócios é desprovido dos efeitos de liderança.

Estudiosos têm retratado a liderança por meio das relações entre líder e seguidor, poder e tomada de decisões, o gerente e o empregado, estilos democrático e autocrático, orientação e controle e várias outras formas de desempenho corporativo (BASS, 1985b; SCHREIBER \& CARLEY, 2006 ).

Por exemplo, características de liderança baseadas na participação, nas interações e interdependências tendem a aceitar melhor a mudança; e estão associadas a níveis mais altos de funcionamento, aprendizagem, inovação e evolução adaptativa (SCHREIBER \& CARLEY, 2006).

Em contrapartida, Day e Schoemaker (2008) observaram que a liderança com foco operacional conserva, regula, perpetua, e fortalece os sistemas existentes. Por fim, líderes com um olhar para o futuro tendem a ser independentes das restrições formais de sistemas, pois focam na visão, e nas opções de resultados a longo prazo (HUNT, 1999).

A seleção de uma teoria de liderança apropriada para este estudo de pesquisa exige uma teoria que descreva características de liderança que mudem ao longo do tempo, que também tenha ajustes de acordo com a situação, e que sejam caracterizadas de forma pragmática, de modo que elas possam ser combinadas com o ciclo de vida de forma independente. 


\section{6.}

\section{As principais correntes sobre liderança}

Nesse trabalho, serão abordadas algumas das principais teorias sobre liderança, iniciando-se pela teoria dos traços de personalidade, corrente que defende que o líder possui características específicas inatas.

A seguir, expandindo as características individuais, a teoria dos estilos de liderança que relaciona a liderança ao estilo de gestão da pessoa, apresentada por White e Lippitt em 1939, também corroborando com a visão comportamental a Teoria da Função (PFEFFER \& SALANICK, 1975) e a Teoria da Gestão de GRID (BLAKE \& MOUTON, 1961), que acrescentou a noção de que os líderes poderiam aprender certas características de liderança e escolher a expressá-las de acordo com a circunstância.

Ainda nesse contexto, as teorias participativas sugeriram que a liderança deve levar em conta a opinião das outras pessoas. O comportamento participativo varia em um espectro de alto a baixo dependendo quanto controle o líder opta em ter (TANNENBAUM \& SCHMITT, 1958).

Como próxima corrente a ser vista, a liderança contingencial ou situacional, avalia a liderança do indivíduo pelo seu estilo versus a situação na qual a liderança é praticada.

Teorias situacionais propõem que os líderes selecionam o melhor caminho de ação com base nas variáveis conjunturais presentes no momento. Um líder não se enquadra em uma única categoria, mas sim é modulado de acordo com as percepções dos liderados, as percepções pessoais e os fatores circunstanciais. Hersey e Blanchard (1986) são os nomes mais familiares associados com a Teoria Situacional.

A última corrente a ser comentada é a liderança autêntica que envolve uma perspectiva moral positiva caracterizada por elevados padrões éticos que guiam o comportamento e a tomada de decisão. Abrangendo líderes mais autoconscientes, relações mais transparentes e éticas nas organizações.

\subsection{1.}

\section{Teoria dos Traços de Personalidade}

A Teoria dos Traços de Personalidade (STOGDILL, 1974), tem origem nos anos 20 e diferencia o líder dos liderados por meio de suas características de personalidade. 
As teorias mais antigas focam no líder separado de outros fatores. Consideram que os líderes são um produto de seus atributos pessoais, que as pessoas herdam certas qualidades e características que lhes permitem ser líderes eficazes.

Estudiosos tentaram identificar características associadas a um líder bemsucedido ou não. Stodgill (1974) identificou conjuntos de características e habilidades que foram consideradas essenciais para um líder de sucesso. Infelizmente, as teorias mais antigas não superaram o desafio empírico, porque o líder-seguidor e os aspectos conjunturais do sucesso de um líder não foram analisados.

\subsection{2.}

\section{Teoria comportamentais}

Os primeiros estudos sobre traços apresentaram falhas que levaram os pesquisadores a seguir a pesquisa de liderança por outra direção.

Cavalvanti et al. (2006), complementa que: "Uma vez que a teoria dos traços não conseguiu ser eficaz para explicar o fenômeno da liderança, as teorias comportamentais buscaram oferecer respostas mais conclusivas sobre a natureza da liderança e as consequências práticas do comportamento do líder".

A seguir serão apresentadas a teoria dos estilo de liderança e do grid gerencial.

\subsubsection{1.}

\section{Teoria dos Estilos de Liderança (WHITE e LIPPITT, 1939)}

Estudada posteriormente a Teoria dos Traços de Personalidade, a Teoria dos Estilos de Liderança foi desenvolvida por White e Lippitt em 1939 (WHITE e LIPPITT, 1960).

Para White e Lippitt (1960) os estilos de liderança se distinguiam em três: autoritário, democrático e liberal (laissez-faire). Esses três estilos participativos, estão relacionados à forma como as decisões são tomadas, autocrática, democrática e laissez-faire. Sendo considerada, a tomada de decisão democrática como o estilo mais eficaz, entendendo que a tomada de decisão autocrática resulta em revolta, e a laissez-faire gera pouca ou nenhuma ação coordenada de decisão. 
A tabela a seguir apresenta um resumo dos três estilos de liderança:

Tabela 3: Estilos de liderança de White e Lippitt

\begin{tabular}{|l|l|l|}
\hline \multicolumn{1}{|c|}{ Autocrática } & \multicolumn{1}{|c|}{ Democrática } & Liberal (laissez-faire) \\
\hline $\begin{array}{l}\text { Apenas o líder estabelece as } \\
\text { diretrizes, sem qualquer } \\
\text { participação do grupo. }\end{array}$ & $\begin{array}{l}\text { As diretrizes são debatidas e } \\
\text { decididas pelo grupo, } \\
\text { estimulado e assistido pelo } \\
\text { líder. }\end{array}$ & $\begin{array}{l}\text { Há liberdade completa para } \\
\text { as decisões grupais ou } \\
\text { individuais, com a } \\
\text { participação mínima do líder. }\end{array}$ \\
\hline $\begin{array}{l}\text { O líder determina as } \\
\text { providências e as técnicas } \\
\text { para a execução das tarefas, } \\
\text { cada uma por sua vez, à } \\
\text { medida que se tornam } \\
\text { necessárias e de modo } \\
\text { imprevisível para o grupo. }\end{array}$ & $\begin{array}{l}\text { O próprio grupo esboça as } \\
\text { atingirno alvo, solicitando } \\
\text { aconselhamento técnico ao líder } \\
\text { quando necessário.. As tarefas } \\
\text { ganham novas perspectivas } \\
\text { com os debates. }\end{array}$ & $\begin{array}{l}\text { A participação do líder no } \\
\text { debate é limitada, } \\
\text { apresentando apenas } \\
\text { materiais variados ao grupo, } \\
\text { esclarecendo que poderia } \\
\text { fornecer informações desde } \\
\text { que as fossem solicitadas. }\end{array}$ \\
\hline $\begin{array}{l}\text { O líder determina qual a } \\
\text { tarefa que cada um deve } \\
\text { executar e qual o seu } \\
\text { companheiro de trabalho. }\end{array}$ & $\begin{array}{l}\text { A divisão de tarefas fica a } \\
\text { critério do próprio grupo e cada } \\
\text { membro tem liberdade de } \\
\text { escolher os seus companheiros } \\
\text { de trabalho. }\end{array}$ & $\begin{array}{l}\text { Tanto a divisão das tarefas } \\
\text { como a escolha dos } \\
\text { companheiros ficam a cargo } \\
\text { do grupo. Ausência de } \\
\text { participação do líder. }\end{array}$ \\
\hline $\begin{array}{l}\text { O líder é dominador e } \\
\text { "pessoal" nos elogios e nas } \\
\text { criticas ao trabalho de cada } \\
\text { membro. }\end{array}$ & $\begin{array}{l}\text { O líder procura ser um membro } \\
\text { normal do grupo, em espírito, } \\
\text { sem encarregar-se muito das } \\
\text { tarefas. O líder é objetivo e }\end{array}$ & $\begin{array}{l}\text { O líder não faz nenhuma } \\
\text { tentativa de avaliar ou de } \\
\text { regular os acontecimentos. } \\
\text { O líder somente faz } \\
\text { comentários sobre as } \\
\text { atividades quando } \\
\text { questionado. }\end{array}$ \\
\hline
\end{tabular}

Fonte: Adaptado de Chiavenato (1997, p. 150)

\subsubsection{2.}

\section{Grid Gerencial (BLAKE e MOUTON,1964)}

Blake e Mouton (1961) mapearam um líder de acordo com a suas preocupações com tarefas (por exemplo, produção) e pessoas. A preferência de um indivíduo por tarefa ou pessoas indicaria seu sucesso da liderança.

O Grid gerencial de Blake e Mouton (1995) é o quadro que mapeia a motivação de acordo com graus de interesse por pessoas ou por realização de tarefas. Sendo que a motivação pode ser por ambos ou por nenhum dos dois, conforme demonstra a seguir a figura e a tabela que correlaciona a escala: 


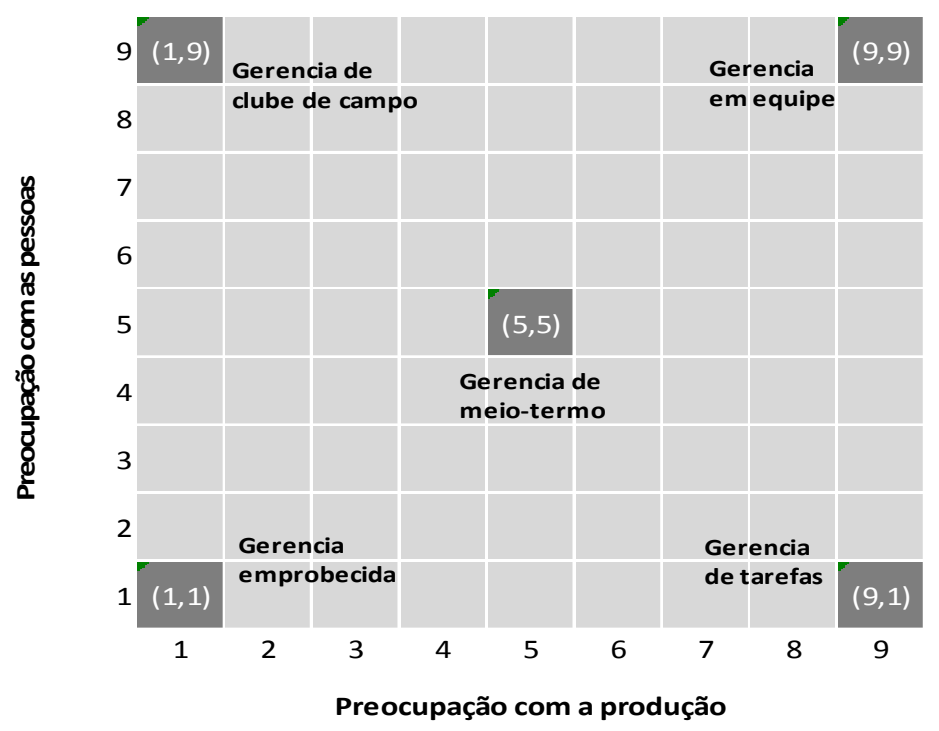

Figura 2: Grid Gerencial

Fonte: Adaptado de BLAKE, R. R.; MOUTON, J. S. O novo grid gerencial. $4^{\circ}$ ed. São Paulo: Pioneira, 1987. p. 13.

Tabela 4: Significado das área do Grid Gerencial

\begin{tabular}{|l|l|}
\hline Estilos & Significado dos Estilos \\
\hline $\mathbf{1 . 9}$ & $\begin{array}{l}\text { Gerência de Clube Campestre } \\
\text { A atenção cuidadosa às necessidades das pessoas visando um } \\
\text { relacionamento satisfatório conduz a um ambiente organizacional e a um ritmo } \\
\text { de trabalho cordial e descontraído. }\end{array}$ \\
\hline $\begin{array}{l}\text { Gerência de Equipe } \\
\text { A realização do trabalho por parte de pessoas ativamente envolvidas; a } \\
\text { interdependência através de um interesse comum nos propósitos da } \\
\text { organização conduz a relações de confiança e respeito. }\end{array}$ \\
\hline $\mathbf{5 . 5}$ & $\begin{array}{l}\text { Gerência do Homem Organizacional } \\
\text { O desempenho adequado da organização se torna possível equilibrando a } \\
\text { necessidade de realizar o trabalho e a manutenção em um nível satisfatório da } \\
\text { disposição de ânimo das pessoas. }\end{array}$ \\
\hline $\begin{array}{l}\text { Gerência Empobrecida } \\
\text { O uso do menor esforço possível na realização do trabalho é o bastante para } \\
\text { manter a participação organizacional. }\end{array}$ \\
\hline $\mathbf{9 . 1}$ & $\begin{array}{l}\text { Autoridade I Obediência } \\
\text { A eficiência das atividades são relacionadas com as condições de trabalho no } \\
\text { sentido de que os elementos humanos interfiram o mínimo possível. }\end{array}$ \\
\hline
\end{tabular}

Fonte: Adaptado de BLAKE, R. R.; MOUTON, J. S. O novo grid gerencial. $4^{\circ}$ ed. São Paulo: Pioneira, 1987. p. 13 


\subsection{3.}

\section{Teorias contingenciais}

A Teoria da Liderança Situacional parte do proposto que os líderes escolhem o melhor curso de ação com base nas variáveis situacionais. Cavalcanti et al.. (2006) descreve que, "Nesses estudos, a atenção sobre a figura do líder é deslocada para o fenômeno da liderança, no qual três aspectos são importantes: o líder, os liderados e o contexto de liderança".

\subsubsection{1.}

\section{Teoria do caminho-objetivo}

$\mathrm{Na}$ teoria Caminho-Objetivo (Path-Goal), House e Mitchell (1974) descreveram o papel do líder viabilizador para os subordinados para alcançarem as metas. Eles definiram quatro estilos de liderança: de apoio, diretiva, participativa e orientada para um objetivo. Podendo ser selecionadas, dependendo principalmente da complexidade da circunstância, e da capacidade e motivação do liderado.

Em seu modelo normativo, Vroom e Yetton (1973) dizem que compromisso e a eficácia das decisões está diretamente relacionada ao nível de participação. Seguindo Vroom e Yetton, processo de tomada de decisão ideal do líder é associado com o tipo de circunstância: autocrático, consultivo, ou orientado a grupos. Yukl (1999) apoiou esse pensamento através da organização de variáveis situacionais em torno do subordinado, do trabalho em grupo, bem como a estrutura de trabalho. A qualidade das decisões melhoram, selecionando a melhores alternativas, o que está relacionado ao nível de participação.

Embora a Teoria Situacional considere os fatores situacionais e diferentes estilos de liderança que mudam com o indivíduo ao longo do tempo, não oferece características de liderança descritivas que podem ser moduladas de forma flexível ao longo do ciclo de vida de uma organização.

Embora seja entendido que a expressão de liderança e seu impacto sobre as decisões e os seguidores está ligada à circunstância, argumenta-se até que ponto a liderança é inerente ou são habilidades aprendidas. Em outras palavras, se as características e os comportamentos de liderança não são inerentes, um líder deveria ser totalmente capaz de aprender e se adaptar, para expressar as características de liderança mais adequadas e eficazes, de acordo com as necessidades do circunstância. 
Observações empíricas e resultados práticos de negócios argumentam que esta posição não é tão simples e, na verdade, não pode ser suportada. Evidências mostram que novas habilidades de liderança são introduzidas para negócios, aprendidas, incorporadas, e usadas. No entanto, nem todas as pessoas se disponibilizam a se tornarem líderes. Além disso, os líderes usam julgamento falho e tomam decisões improdutivas, apesar da formação e da experiência dos outros.

A seguir, outras teorias sobre liderança situacional serão apresentadas.

\subsubsection{2.}

\section{Teorias situacionais}

Nessa teoria Tannenbaum e Schmidt (1958), consideram um modelo com uma escala de sete pontos, que varia num contínuo entre os conceitos de autoridade (autoritarismo) e liberdade (democracia).

Nesse modelo o líder tem sua estratégia feita com base em três forças: do líder (seus valores, sua competência); da equipe subordinada (aspiração por independência ou dependência, responsabilidade, conhecimento e experiência) e, da situação (tipo de organização, natureza da tarefa e tempo).

A seguir a Figura 3 ilustra a teoria dos dois autores:

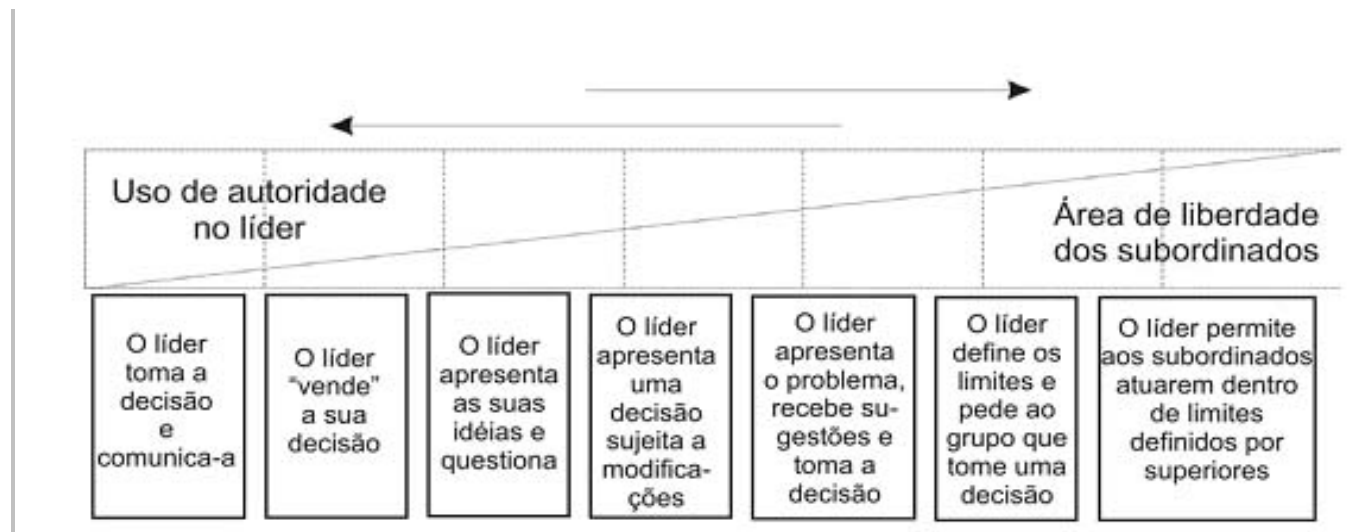

Figura 3: Modelo de liderança situacional de Tannenbaum e Schmidt. Fonte: Adaptado de Chiavenato (2004, p. 105).

O quadro acima pretende mostrar que a liderança fica centralizada na figura do líder, sendo situado no ponto próximo à extrema esquerda do quadro quando as atividades são rotineiras e repetitivas, e o contrário, ou seja, quando as atividades são complexas, exigem maior participação dos subordinados, essa posição fica mais próxima a direita do gráfico. 
Esse contínuo pode se estender do comportamento de um líder democrático até incluir um estilo laissez-faire, que apresenta um ambiente de grande liberdade aos subordinados.

O modelo de Hersey e Blanchard (1969), tem como base a inter-relação de três variáveis: comportamento das tarefas, comportamento do relacionamento e nível de maturidade ou desenvolvimento dos liderados. Os conceitos de maturidade e as escalas aos níveis serão apresentados a seguir.

A maturidade para Hersey e Blanchard (1986), é: “(..) capacidade e a disposição das pessoas de assumir a responsabilidade de dirigir seu próprio comportamento". A classificação de maturidade é feita numa escala de um a quatro, a primeira escala tem o menor grau e a quarta escala a maior grau maturidade (M1, M2, M3, M4). Para o modelo os graus podem ser explicados da seguinte forma:

- M1 é a incapacidade de realização das tarefas pelas pessoas, aliada à falta de vontade para assumir responsabilidades;

- M2 é uma insuficiência dessa capacidade,

- M3 é demonstrada a capacidade de realização das tarefas, mas com motivações instáveis;

- M4, é demonstrada grande capacidade de realizar as tarefas e alta motivação para assumir responsabilidades.

A seguir os diferentes estilos de liderança propostos por Hersey e Blanchard (1986):

- E1: Determinador - Altamente orientado para as tarefas e baixo relacionamento. Líder define os papéis e equipe é informada das tarefas

- E2: Persuasão / Vendedor - Alta orientação para as tarefas e alta orientação para as pessoas. Líder apóia e direciona a equipe na execução das tarefas conforme definido por ele.

- E3: Compartilhador - Pouca ênfase nas tarefas e alta orientação para as pessoas. O líder é um facilitador, e o processo decisório é compartilhado com líder e a equipe.

- E4: Delegado - Pouca ênfase nas tarefas e baixo relacionamento. O líder dá pouca assistência a equipe. Em geral funciona com equipes com alto grau de maturidade para a execução de tarefas. 
A seguir o quadro resumo da teoria de liderança Situacional de Hersey e Blanchard:

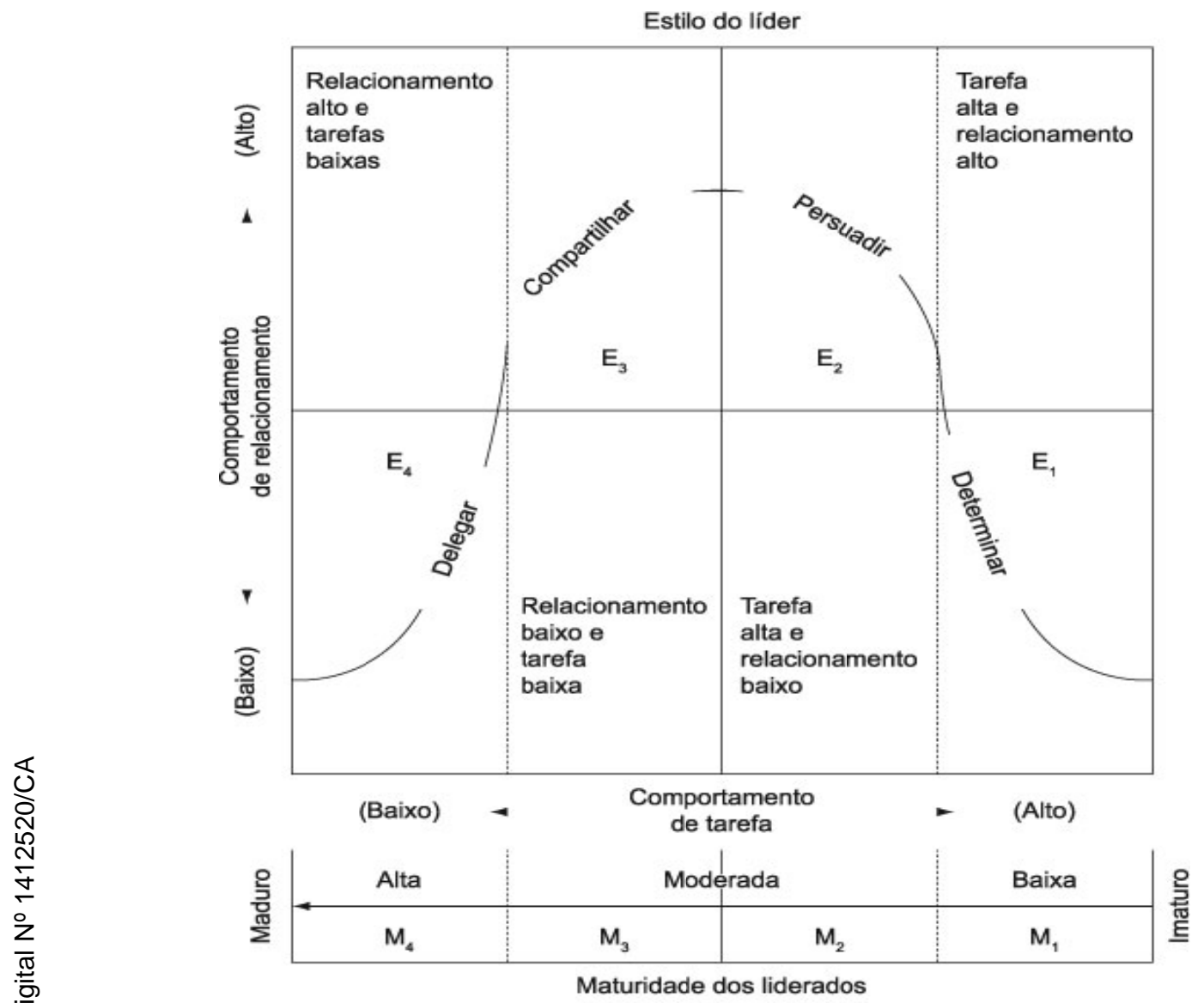

Figura 4: Modelo de liderança situacional de Hersey e Blanchard

Fonte: Hersey e Blanchard (1986, p. 189).

\subsection{4.}

\section{Evolução das teorias contingências}

Como extensão das teorias contingenciais de liderança alguns autores pesquisaram o fenômeno da liderança transacional e da liderança transformacional (BASS et al., 2003).

As teorias de liderança transacionais e transformacionais são um conjunto de teorias descritivas e com base prática, aprofundada na interface de líderliderado que é afetada pelas circunstâncias. Os líderes transacionais gerenciam por meio de um sistema de recompensas e punições diretamente ligados ao alcance do sucesso ou fracasso das metas. Em contraste, os líderes transformacionais inspiram e motivam seus seguidores, ajudando-os a ver o significado maior do papel que eles desempenham. Quando combinados, um continuum de características de liderança pode ser formado, que pode ser facilmente adaptado à estrutura de múltiplas fases dos ciclos de vida da organização. 
Em sua obra seminal, Liderança, Burns (1978) introduziu a distinção entre a liderança transformacional e transacional, e Bass (1985a) mais tarde elaborou com base nessa conceituação a identificação de oito dimensões de liderança agrupados em dois domínios. Tanto Burns (1978) quanto Bass descrevem líderes por suas ações e o impacto dessas ações sobre os liderados (BASS, 1985b).

A liderança transacional considera que a liderança eficaz é baseada no intercâmbio recíproco entre líderes e liderados. Trata-se de dar aos empregados algo em troca de seu cumprimento e aceitação da autoridade, geralmente sob a forma de incentivos, tais como aumentos de salário ou um aumento de status. Comportamentos transacionais incluem persistência, competência, autoridade e pragmatismo, sendo preferido para operar em um ambiente de comando e controle, de estilo hierárquico (BASS, 1990; YUKL, 1999). Quatro dimensões deste domínio são: a gestão do contingente de recompensa, gerenciamento por exceção-ativa, gestão por exceção-passivo e gestão laissez-faire (BASS, 1985a).

Em contraste, a liderança transformacional adota a mudança e a inovação, amplia gestão para incluir e elevar o interesse dos funcionários, e estimula o conhecimento e a participação (AVOLIO et al., 1999; BASS, 1990; HUNT, 1999). Esses líderes tendem a aceitar a mudança eriscos.

Especificamente, Burns (1978) e Bass (1985a) apontam como características e comportamentos transformacionais: a influência idealizada, motivação inspirada, estímulo intelectual e consideração individual. A influência idealizada é uma característica dos líderes que angariam lealdade e são altamente considerados, porque eles exibem elevados padrões morais e éticos. A motivação inspirada descreve a capacidade do líder em fornecer uma visão clara. Esses líderes obtêm apoio para essa visão por meio de entusiasmo, anos de confiança, linguagem persuasiva e carisma.

Os líderes transformacionais fornecem estimulo intelectual para apoiar a visão de futuro, incentivando o pensamento divergente e original, e desafiando do status quo, levando à inovação. Finalmente, os benefícios das dimensões transformacionais ocorrem por meio da construção da resiliência e lealdade nos liderados, dando resposta às suas necessidades de desenvolvimento e de crescimento (AVOLIO et al., 1999; BASS, 1990). 
Os líderes transacionais são pragmáticos e avessos ao risco, desejam reduzir variância e manter o status quo. Ao exercer a recompensa contingente, o líder esclarece expectativas e oferecem recompensas por metas atingidas. $O$ esclarecimento de metas e objetivos e o reconhecimento quando as metas são realizadas podem resultar em indivíduos ou grupos que atingem níveis de performance esperados. No que se refere ao comportamento, pode se dizer que a liderança é centrada na troca dos recursos. Isto é, os líderes fornecem suporte e recursos tangíveis ou intangíveis aos seguidores em troca de seus esforços e desempenho

Ao invés de inspirar inovação e mudança, os líderes transacionais desenvolvem um plano e, em seguida, gerenciam esse plano por exceção, ativa ou passivamente e fazem a implementação de medidas corretivas apenas quando necessário. Bass (1985a) considera como quarta dimensão transacional, a gestão laissez-faire, pensada como uma expressão de evasão ao invés de liderança; por isso as vezes, não está incluída nessa esfera e não é considerada neste estudo.

Estilos de liderança transacional e transformacional têm o seu valor dentro das organizações, dependendo da circunstância e da fase. Uma vez combinados, as sete características de liderança transformacionais e transacionais podem ser alinhadas em um continuum, similar ao continuum lídergerente proposto por Kotter (1990). Como a organização se move para a frente a partir de uma fase para a seguinte, um subconjunto de diferentes de características se torna idealmente eficaz.

Seguindo o padrão desenvolvido para os diferenciais da fase do ciclo de vida organizacional, um conjunto diferente de características de liderança apoiará o estilo criativo, inovador e menos formais dos inovadores, técnicos, das fases iniciais, em oposição aos traços que melhor se adequam a burocracia, a formalização, o comportamento eficiente, a relação custo-benefício, e de mercado,com foco das fases do ciclo de vida posteriores.

Especificamente, características transacionais servem melhor a empresa do que as características de transformação durante a Fase 4 , permitindo o refinamento dos sistemas, reduzindo variância, e ajustando os custos operacionais. No entanto, as características transformacionais estão melhores posicionadas para promover a Fase 1, a criatividade, a descoberta, a inovação, e se libertar das fronteiras, para formar uma nova visão para o futuro (BASS, 1990; BASS, JUNG, AVOLIO, e BERSON, 2003). 
Segue tabela com resumo das características do líder transacional e transformacional, segundo Bass et al. (2003).

Tabela 5: Características do líder transacional e transformacional

\begin{tabular}{|c|c|}
\hline Líder transacional & Líder transformacional: \\
\hline $\begin{array}{l}\text { Recompensa Contingente: O líder } \\
\text { negocia a troca de cumprimento nas } \\
\text { tarefas por recompensas ou benefícios; }\end{array}$ & $\begin{array}{l}\text { Carisma:O líder é admirado e desperta } \\
\text { identificação, é respeitado e confiável. Atua } \\
\text { como um modelo.Considera as } \\
\text { necessidades da equipe como sua; }\end{array}$ \\
\hline $\begin{array}{l}\text { Gestão por exceção (ativa): O líder } \\
\text { observa e procura desvios da regras e } \\
\text { padrões, tomando atitude corretiva } \\
\text { quando necessário. Busca por } \\
\text { sistemas de preventivos de falhas. }\end{array}$ & $\begin{array}{l}\text { Inspirador e Motivador: O líder estimulam a } \\
\text { equipe, através de significado e desafio. } \\
\text { Encoraja a equipe a visualizar futuros } \\
\text { atraentes. Demonstra entusiasmo e } \\
\text { otimismo. }\end{array}$ \\
\hline $\begin{array}{l}\text { Gestão por exceção (passiva): O líder } \\
\text { só atua quando os padrões não são } \\
\text { alcançados. Espera ser notificado de } \\
\text { falhas pelos subordinados. Busca a } \\
\text { manutenção do status quo. }\end{array}$ & $\begin{array}{l}\text { Estimulo Intelectual:Estimula seguidores } \\
\text { questionando suas premissas, reformulando } \\
\text { problemas e analisando velhas situações de } \\
\text { novas maneiras. }\end{array}$ \\
\hline $\begin{array}{l}\text { Lassez-Faire: O líder evita a tomada } \\
\text { de decisão e tentar se eximar das } \\
\text { responsabilidades. }\end{array}$ & $\begin{array}{l}\text { Consideração Individualizada: O líder } \\
\text { presta atenção a necessidade de } \\
\text { desenvolvimento de cada individuo. }\end{array}$ \\
\hline
\end{tabular}

Fonte: Adaptado de Bass et al. (2003).

Por identificar o fenômeno dos estilos de liderança de acordo com as ocasiões e cenários apresentados nas duas empresas selecionadas, e por ter o foco dado nas diferenças entre as lideranças transacionais e transformacionais a teoria contingencial de liderança foi aplicada nesse estudo dando continuidade a proposta metodológica do estudo inicial de 2009. Foi considerado um estilo que dialoga com as fases do ciclo de vida com base nos pilares da liderança situacional de Bass (1990). Das muitas teorias de liderança, as características englobadas dentro das teorias de liderança transformacional e transacional, são as que tem melhor ajuste com as cinco fases do ciclo de vida (SCHREIBER \& CARLEY, 2006). 


\subsection{5. \\ Liderança autêntica}

A liderança autêntica nas organizações pode ser definida como:

"um processo desenhado a partir das capacidades psicológicas positivas e de um contexto organizacional altamente desenvolvido, o que resulta numa maior autoconsciência e num comportamento positivo autorregulado por parte dos líderes e dos colegas, fomentando um auto desenvolvimento positivo" (LUTHANS \& AVOLIO, 2003, p. 243).

Diversos autores (e.g. AVOLIO, BRUCE J., GARDNER, W. L., WALUMBWA, F. O., LUTHANS, F., MAY, D. R., 2003) argumentaram que a liderança autêntica inclui uma perspectiva moral positiva caracterizada por elevados padrões éticos que guiam o comportamento e a tomada de decisão.

Com base nos estudos de Gardner et al. (2005), foi proposta uma nova definição para a liderança autêntica:

"é um padrão do comportamento do líder que promove tanto as capacidades psicológicas positivas como o clima ético positivo, para fomentar a autoconsciência, a perspectiva moral internalizada, o processamento equilibrado da informação e a transparência relacional no trabalho dos líderes com os seus subordinados, fomentando o autodesenvolvimento positivo" (p. 94).

Inicialmente, estes autores consideravam que a liderança autêntica era composta por cinco componentes distintas mas relacionadas: autoconsciência, transparência relacional, regulação interna (i.e. comportamento autêntico), processamento de informação equilibrado, e perspectiva moral positiva.

Posteriormente, consideraram que ambos os conceitos eram conceitualmente equivalentes (ambos envolviam exibir um comportamento que é consistente com os valores próprios e padrões internos), juntaram o processo de regulação interna e a perspectiva moral positiva numa só dimensão, designada perspectiva moral interna, que traduz a consistência entre os valores e as ações dos líderes.

Assim, a autoconsciência refere-se à compreensão das próprias forças e fraquezas e da natureza multifacetada de si próprio, e estar ciente do seu impacto nas outras pessoas (KERNIS, 2003).

A transparência relacional implica apresentar o seu "eu autêntico" aos outros (KERNIS, 2003). O processamento equilibrado refere-se ao fato dos líderes analisarem objetivamente os dados antes de tomarem decisões, solicitando também pontos de vista que questionem as suas posições mais profundas (GARDNER et al., 2005). 
Finalmente, a perspectiva moral interna refere-se a uma forma de autoregulação internalizada e integrada, que é guiada por padrões e valores morais internos e não devido a pressões organizacionais ou da sociedade, resultando numa tomada de decisão e comportamento que é consistente com estes valores internos (AVOLIO \& GARDNER, 2003; GARDNER et al., 2005).

As quatro dimensões da liderança autêntica consideradas encontram-se expostas na Tabela 6.

Tabela 1: As várias dimensões da liderança autêntica

\begin{tabular}{|l|l|}
\hline \hline \multicolumn{1}{|c|}{ Dimensões } & \multicolumn{1}{c|}{ Características } \\
\hline \hline Auto - Consciência & $\begin{array}{l}\text { Compreensão das próprias forças e fraquezas e da natureza } \\
\text { multifacetada de si próprio, e estar ciente do seu impacto nas outras } \\
\text { pessoas. }\end{array}$ \\
\hline Tr ansparência Relacional & Apresentação do seu «eu autêntico» aos outros. \\
\hline Per spectiva moral interna & $\begin{array}{l}\text { Forma de auto-regulação interna e integrada, que é guiada por } \\
\text { padrões e valores morais internos e não devido a pressões } \\
\text { organizacionais ou da sociedade, resultando numa tomada de decisão } \\
\text { e comportamento que é consistente com estes valores internos }\end{array}$ \\
\hline $\begin{array}{l}\text { Processamento equilibrado de } \\
\text { infor mação }\end{array}$ & $\begin{array}{l}\text { Análise objectiva dos dados antes de tomar decisões, solicitando } \\
\text { pontos de vista que questionem as suas posições mais profundas. }\end{array}$ \\
\hline
\end{tabular}

Fonte: Adaptado de Walumbwa, Avolio, Gardner, Wernsing e Peterson (2003)

A liderança autêntica é apresentada como a base para criar confiança, ajudar as pessoas a desenvolver as suas forças e a serem mais positivas, a abrir o seu pensamento, a adicionar valor e sentido sobre aquilo que está certo nas decisões, e a melhorar a performance global da organização ao longo do tempo (AVOLIO et al., 2004).

Avolio e Gardner (2005) também fomentam a idéia de que a liderança autêntica é importante nas organizações, pois ajuda os seus elementos a encontrar sentido e compromisso com o trabalho, promovendo uma estrutura e um ambiente que apóia tanto os líderes como os seus seguidores.

\subsection{6.}

\section{Liderança e o desempenho organizacional}

Quanto o desempenho de uma organização é influenciado por seu líder é uma questão que tem sido objeto de estudos há anos nos campos da sociologia, comportamento organizacional e gestão estratégica. Embora a pesquisa sobre esta questão ser ainda inconclusiva, duas escolas de pensamento evoluíram a partir dos resultados primários de estudos anteriores. 
Uma escola afirma que o líder não é capaz de alterar significativamente o desempenho da organização (por exemplo, LIEBERSON \& O'CONNOR, 1972; MINTZBERG, 1979). O estudo de Lieberson e O'Connor é frequentemente citado como favorável a esta visão. Este ponto de vista, sustenta que o desempenho organizacional não pode ser atribuído a líderes individuais porque o desempenho é um fenômeno emergente que envolve, interações não lineares complexos entre múltiplas variáveis em um sistema dinâmico aberto a influências externas (MARION e UHL-BIEN, 2001).

Um segundo ponto de vista argumenta que os líderes têm um impacto significativo e possivelmente crucial sobre o desempenho das organizações que dirigem (THOMAS, 1988). Este ponto de vista argumenta que os líderes são capazes de ter muita influência em sua organização, porque eles são figuraschave na definição de objetivos, determinação de estratégias, organização dos fluxos de comunicação, na orientação e motivação dos empregados.

Respondendo ao trabalho de Lieberson e O'Connor, Thomas (1988) realizou um estudo concluindo que, visto como um todo, existem poucas evidências válidas disponíveis sobre a relação líder e performance, e que envolvem dois pontos básicos: (a) diferenças de liderança são responsáveis por variações de desempenho dentro de empresas em um grau elevado, e (b) os impactos das diferenças na liderança são geralmente insuficientes para sobrepujar as diferenças inerentes as empresas.

Craig (2006) argumentou que a pesquisa sobre suces são gerencial ao longo dos últimos 20 anos tem consistentemente encontrado uma relação entre liderança e desempenho organizacional, sendo medida por uma variedade de indicadores (por exemplo, BARNEY,1991; THOMAS, 1988).

Day \& Lord (1988) também examinaram as conclusões apresentadas pelo estudo de Lieberson e O'Connor. Eles concluíram que os resultados da investigação que examinou o impacto da liderança no desempenho quando interpretadas corretamente, mostram um efeito consistente em decorrência da sucessão de liderança, apresentando de $20 \%$ a $45 \%$ de mudanças nos resultados organizacionais relevantes.

Corroborando, Craig (2006) argumenta que a pesquisa sobre sucessão gerencial ao longo dos últimos 20 anos, encontrou consistentemente uma relação entre a liderança e desempenho organizacional, sendo medido por uma variedade de indicadores (por exemplo, BARNEY, 1991; THOMAS, 1988). Usando metodologias diferentes, os autores desses estudos convergem para a 
conclusão de que mudanças na liderança são seguidas por mudança no desempenho das empresas (KAISER et al., 2008).

\section{7.}

\section{Teorias sobre o desempenho}

\subsection{1. \\ Definições}

Carneiro et al. (2007) afirmam existir na área da administração, várias definições de desempenho, porém não há uma concordância sobre a melhor definição e sobre quais critérios deveriam ser seguidos de acordo com as diversas abordagens. São sugeridos pelo autor quatro abordagens principais em na qual o desempenho deveria ser definido, são elas: sobrevivência, medidas contábeis, perspectivas de múltiplos stakeholders e medidas de valor presente.

O desempenho organizacional para Neely et al. (1995) é o processo de quantificar a eficiência e eficácia das ações.

A definição adequada sobre um indicador de desempenho para Callado et al. (2008), diz respeito primeiramente em entender seu significado institucional, assim como da abrangência da sua aplicação.

Nesse estudo não serão listadas todas possíveis definições sobre desempenho, e também não se propõe a identificar a melhor definição para o termo, mas sim usar a conceituação para dar continuidade aos estudos sobre como a liderança afeta o desempenho dos casos em questão.

\subsection{2.}

\section{Importância do estudo do desempenho}

Venkatraman e Ramanujam (1986) entendem que o sucesso no desempenho organizacional, passa pela empresa por possuir um gerenciamento estratégico, e que conceito do desempenho nos negócios envolve três dimensões: teórica, empírica e gerencial.

Já o controle e a medição do desempenho são favoráveis as empresas pois geram insumos à tomada de decisão. Dentre as vantagens da utilização dos sistemas de medição de desempenho, está o suporte ao planejamento estratégico, uma vez que os sistemas de medição de desempenho monitoram o cumprimento da estratégia, e a comunicação de forma mais clara a estratégia da empresa, por meio de métricas, possibilitando um melhor entendimento dos objetivos a serem alcançados. 
As principais razões para se criar e acompanhar as medidas de desempenho nas corporações são enfatizadas por Neely (1999), como:mudança nas naturezas do trabalho; aumento da competição; iniciativas isoladas de melhorias; certificados internacionais e nacionais de qualidade; mudança das regras organizacionais; mudança nas demandas externas e poder da tecnologia da informação.

\subsection{3.}

\section{Problemas e limitações em medir o desempenho}

Para Fey \& Denison (2003), mesmo havendo uma convergência entre muitos autores para definição de desempenho, a forma de mesurar e as métricas são temas divergentes e largamente pesquisado na administração.

De acordo com Neely et al. (1995), os estudos sobre o desempenho na literatura são múltiplos e cada autor tende a focalizarem diferentes perspectivas ao elaborar um conjunto de medidas de desempenho.

A abordagem do desempenho como uma variável dependente é feita por Macedo-Soares (2000). Dentre as variáveis, o autor destacou como variáveis principais e independentes: pessoas, fatores internos organizacionais e tecnologias. No entanto, como dito anteriormente, o desempenho foi estudado como dependente dessas variáveis principais.

Para Dess e Robinson Jr (1984) a dificuldade de medir o desempenho nas pequenas empresas é devido a noção de sucesso ou fracasso, e o que nessas empresas se enxerga quanto a ótica do desempenho. Além de existir uma dificuldade obtenção de medidas formais de desempenho. E mesmo que as informações estejam disponíveis há uma grande possibilidade dessas informações estarem erradas em função de diferenças nos processos contábeis.

Numa pequena empresa, Neely et al. (1995) relatam que o desempenho pode ser medido pelo sentimento dos administradores, sendo o mais comum relatar sucesso ou fracasso.

A seguir serão descritas as classificações dos indicadores desempenho quanto a sua natureza, com objetivo de descrever a diferença entre os tipos de indicadores de desempenho e abordar os autores que elaboraram as métricas de desempenho em suas pesquisas. 


\subsection{4.}

\section{Classificação dos indicadores de desempenho}

Carneiro et al. (2007) classificaram as dimensões do desempenho de acordo com suas naturezas conceituais e metodológicas, conforme a seguir na Tabela 7.

Também nessa mesma tabela, são abordada as dimensões conceituais do desempenho de acordo com as óticas dos stakeholders, as classes de medida, as perspectivas de referência e a orientação temporal e as questões metodológicas, estão representadas nos subgrupos: nível de análise, objetividade dos dados e fonte dos dados.

Tabela 7: Modelo genérico para caracterização do desempenho organizacional

\begin{tabular}{|c|c|c|c|}
\hline \multicolumn{4}{|c|}{ Macro-dimensões conceituais } \\
\hline $\begin{array}{c}\text { Ótica dos } \\
\text { stakeholders }\end{array}$ & $\begin{array}{c}\text { Classes de } \\
\text { medidas }\end{array}$ & $\begin{array}{c}\text { Perspectiva } \\
\text { de referência }\end{array}$ & $\begin{array}{c}\text { Orientação } \\
\text { Temporal }\end{array}$ \\
\hline $\begin{array}{l}\text { - Acionistas } \\
\text { - Clientes } \\
\text { - Empregados } \\
\text { - Executivos e } \\
\text { - Gerentes } \\
\text { - Credores } \\
\text { - Fornecedores } \\
\text { - Canais de } \\
\text { distribuição } \\
\text { - Parceiros } \\
\text { - Sindicatos } \\
\text { - Beneficiários de } \\
\text { pensões } \\
\text { - Membros do } \\
\text { Conselho de } \\
\text { - Adm } \\
\text { local } \\
\text { - Público em } \\
\text { geral } \\
\text { - ONG's } \\
\text { - Governos }\end{array}$ & $\begin{array}{l}\text { - Contábeis- } \\
\text { financeiras } \\
\text { - De clientes / } \\
\text { De mercado } \\
\text { - De processos } \\
\text { internos } \\
\text { (eficiência ou } \\
\text { eficácia) } \\
\text { - De inovação e } \\
\text { aprendizado } \\
\text { - Sociais } \\
\text { - Ambientais } \\
\text { - Comportamen- } \\
\text { tais / Situacio- } \\
\text { nais } \\
\text { - Gerais / } \\
\text { Agregadas }\end{array}$ & $\begin{array}{l}\text { - Absoluta } \\
\text { - Relativa } \\
\text { - Média dos } \\
\text { (principais) } \\
\text { competi- } \\
\text { dores } \\
\text { - Benchmark } \\
\text { - Outras } \\
\\
\text { operações } \\
\text { da empresa } \\
\text { - Objetivos } \\
\text { pré-defi- } \\
\text { nidos }\end{array}$ & $\begin{array}{l}\text { - Transversal/ } \\
\text { Estática } \\
\text { - Passado } \\
\text { recente } \\
\text { - Expectati- } \\
\text { vas de } \\
\text { futuro } \\
\text { - Longitudinal / } \\
\text { Dinâmica } \\
\text { - Mudanças } \\
\text { no passado } \\
\text { recente } \\
\text { - Mudanças } \\
\text { nas expec- } \\
\text { tativas de } \\
\text { futuro }\end{array}$ \\
\hline
\end{tabular}

\begin{tabular}{|c|c|c|}
\hline \multicolumn{3}{|c|}{ Macro-dimensões metodológicas } \\
\hline $\begin{array}{l}\text { Nível de } \\
\text { análise }\end{array}$ & $\begin{array}{c}\text { Objetividade } \\
\text { dos dados }\end{array}$ & $\begin{array}{c}\text { Formato dos } \\
\text { dados }\end{array}$ \\
\hline $\begin{array}{ll}\text { - } & \text { U.E.N. / } \\
& \text { Divisão } \\
\text { - } & \text { Conjunto de } \\
& \text { U.E.N. } \\
\text { - Empresa } \\
\text { - } \\
\text { Combinação } \\
\text { específica } \\
\text { produto- } \\
\text { mercado }\end{array}$ & $\begin{array}{l}\text { - Objetivos } \\
\text { - De fontes } \\
\text { secundárias } \\
\text { - Auto-repor- } \\
\text { tados } \\
\text { - Subjetivos / } \\
\text { Perceptuais } \\
\text { (fontes primá- } \\
\text { rias) } \\
\text { - Auto-avali- } \\
\text { ação } \\
\text { - Avaliação } \\
\text { pelos com- } \\
\text { petidores } \\
\text { - Avaliação } \\
\text { por espe- } \\
\text { cialistas } \\
\text { - Subjetivos / } \\
\text { Perceptuais } \\
\text { (fontes secun- } \\
\text { dárias) } \\
\text { - Material de } \\
\text { casos }\end{array}$ & \begin{tabular}{|l} 
- \\
Qualitativos \\
(métricos) \\
- Intervalares \\
- Escalares \\
- Quantitativos \\
(não-métricos) \\
- Nominais \\
- Ordinais
\end{tabular} \\
\hline
\end{tabular}

Fonte: Carneiro et al. (2007, p. 3)

Além disso Carneiro et al. (2007) indica que cada stakeholder tem uma expectativa, desta forma o desempenho deve ser medido por meio de diversas dimensões. A tabela abaixo apresenta a análise entre os diferentes stakeholders e suas demandas pelo desempenho:

Tabela 2: Visão parcial das contribuições e expectativas de diversos Stakeholders

\begin{tabular}{|l|l|l|}
\hline \multicolumn{1}{|c|}{ Stakeholders } & \multicolumn{1}{c|}{ Contribuições } & \multicolumn{1}{c|}{ Expectativas } \\
\hline acionistas & capital & retorno sobre os investimentos \\
\hline clientes & receitas & qualidade dos produtos, preços justos e responsividade \\
\hline empregados/gerentes & trabalho & salário justo, condições de trabalho, oportunidade de carreira \\
\hline fornecedores & insumos & pagamentos justos e no prazo \\
\hline credores & recursos financeiros & remuneração justa e repagamento confiável \\
\hline comunidade & infraestrutura & responsabilidade social e ambiental \\
\hline governos & arcabouço legal & pagamento de impostos e cumprimento das leis \\
\hline
\end{tabular}

Fonte: Carneiro et al. (2007, p. 4) 
Natal (2005), aponta que diversos autores classificam os indicadores de desempenho em dois tipos: financeiros e não-financeiros.

Os métodos de classificação que tratam aspectos financeiros e não financeiros, para Macedo \& Silva (2004), são importantes pois o desempenho nas empresas é afetado por variáveis de ambas as naturezas. As métricas financeiras tratam em geral dos resultados econômicos e financeiros.

Já a métrica física, é uma forma subjetiva de avaliar os resultados atingidos, não envolve números e por isso chamada de medidor não financeiro. Alguns exemplos dessas métricas são: participação de mercado, volume de produção, clima organizacional, satisfação dos consumidores, cultura empresarial, satisfação dos empregados, acionistas, entre outras.

A incorporação das duas métricas para avaliar o desempenho da empresa é chamada de modelo híbrido de avaliação de desempenho, e compreende um modelo financeiro e não financeiro ao mesmo tempo. Essas três divisões (financeira, não-financeira e híbrida) serão analisadas na seção a seguir.

\subsection{5. \\ Indicadores financeiros de desempenho}

Também chamadas de indicadores contábeis de desempenho, as medidas financeiras de desempenho, são indicadores referentes ao passado das empresas e podem ser divididas em valores absolutos ou relativos. Os valores absolutos são pontuais e os relativos são aqueles comparados com outros períodos. Exemplos de índices absolutos são: faturamento, lucro, volume de vendas e número de funcionários (RIBEIRO, 2004).

Há também os índices da análise de demonstrações financeiras da contabilidade empresarial. Segundo Brigham et al. (2001), os índices de demonstrações financeiras são separados em grupos, como demonstrados na lista a seguir:

- Índice de Liquidez: Tem o objetivo medir a capacidade de solvência da empresa, o quanto ela pode, com seus recursos próprios (ativos) cumprir com as obrigações.

- Índice de administração de ativos ou índice de atividade: Esse item envolve os giros dos estoques, o prazo médio de recebimento dos clientes, o prazo médio de pagamento aos fornecedores e o índice de giro dos ativos da empresa. 
- Índice de Endividamento: Mede o quanto a empresa se endividou em relação a seus ativos. Os sub-índices desse grupo são o índice de endividamento, o grau de cobertura dos juros e o grau de cobertura das despesas financeiras fixas.

- Índice de Lucratividade: Mostram os efeitos combinados da liquidez, do gerenciamento de ativos e da dívida sobre o resultado operacional. A principal e mais utilizada pelos administradores é o retorno sobre o patrimônio líquido (ROE), que mede o quanto a empresa remunera o investimento dos acionistas.

- Índice de valor de mercado: Relaciona o valor das ações da empresa ao seu lucro e ao valor de livro das ações. Os índices são: índice preço/lucros e índice valor de mercado/valor de livro.

\subsection{6.}

\section{Indicadores não financeiros de desempenho}

Para Kaplan \& Norton (2005), os indicadores financeiros de desempenho foram eficazes para as empresas na era industrial, e atualmente com ambiente mais dinâmico e competitivo eles seriam obsoletos, por tratar do que já ocorreu ou explicar o passado. $E$ isolados acabam não direcionando a tomada de decisão futura.

De acordo com Kanji e Sá (2007) existem indicadores complexos com dados não financeiros, mas com pouco destaque para qualidade nos serviços prestados, a satisfação dos consumidores e objetivos alcançados.

A tabela a seguir exibe as diferenças entre a visão clássica e a visão inovadora dos indicadores de desempenho:

Tabela 9: Visão tradicional versus inovadora de medidores de desempenho

\begin{tabular}{|l|l|}
\hline Sistemas de Métricas Tradicionais & Sistemas de Métricas Inovadoras \\
\hline Foco Unidimensional (Indicadores & $\begin{array}{l}\text { Foco Multidimensional (Combinam uma } \\
\text { variedade de Indicadores) }\end{array}$ \\
\hline Baseado no custo/oportunidade & Baseado no Valor \\
\hline Orientação de Curto Prazo & Orientação de Longo Prazo \\
\hline Medidores de desempenho isolados & Medidores interdependentes \\
\hline Ênfase no desempenho individual & Énfase no desempenho do time \\
\hline Predominância de medidas funcionais & Medidas Transversais (processos) \\
\hline Foco no controle & Foco no aprendizado \\
\hline $\begin{array}{l}\text { Visão determinística da empresa e do } \\
\text { contexto }\end{array}$ & $\begin{array}{l}\text { Aceita incertezas e necessidades de } \\
\text { permanente revisão nos indicadores }\end{array}$ \\
\hline Fonte: Adaptação de Kanii e Sá (2007,p. 49-56) & \multicolumn{2}{|c|}{} \\
\hline
\end{tabular}

Fonte: Adaptação de Kanji e Sá (2007, p. 49-56) 
Neely (1999) numa compilação de autores lista as desvantagens de utilizar apenas medidas financeiras para medir o desempenho de uma empresa. Fazem parte dessa lista: encoraja uma visão de curto prazo; limita o olhar estratégico e falha na abordagem da qualidade; desestimula a melhoria continua e limita por não considerar informações de clientes e concorrentes.

Contudo, utilizar de medidores não-financeiros sem analises mais criticas pode trazer uma visão distorcida da realidade. Segundo Lanz (2004), um desempenho satisfatório na ótica dos consumidores pode significar que a organização oferece boa qualidade nos produtos e serviços com preço satisfatório para os clientes. Entretanto, o preço pode ser satisfatório para os clientes e não para os acionistas, por exemplo. Isso mostra que é necessário a utilização correta dos medidores de desempenho e ponderá-lo de acordo com cada parte envolvida conforme a metodologia de Carneiro et al. (2007).

Marcoulides e Heck (1993) estudaram a relação entre cultura e desempenho organizacional e apresentaram uma proposta de um modelo que mede 26 variáveis num contexto de cinco dimensões conforme exposto a seguir:

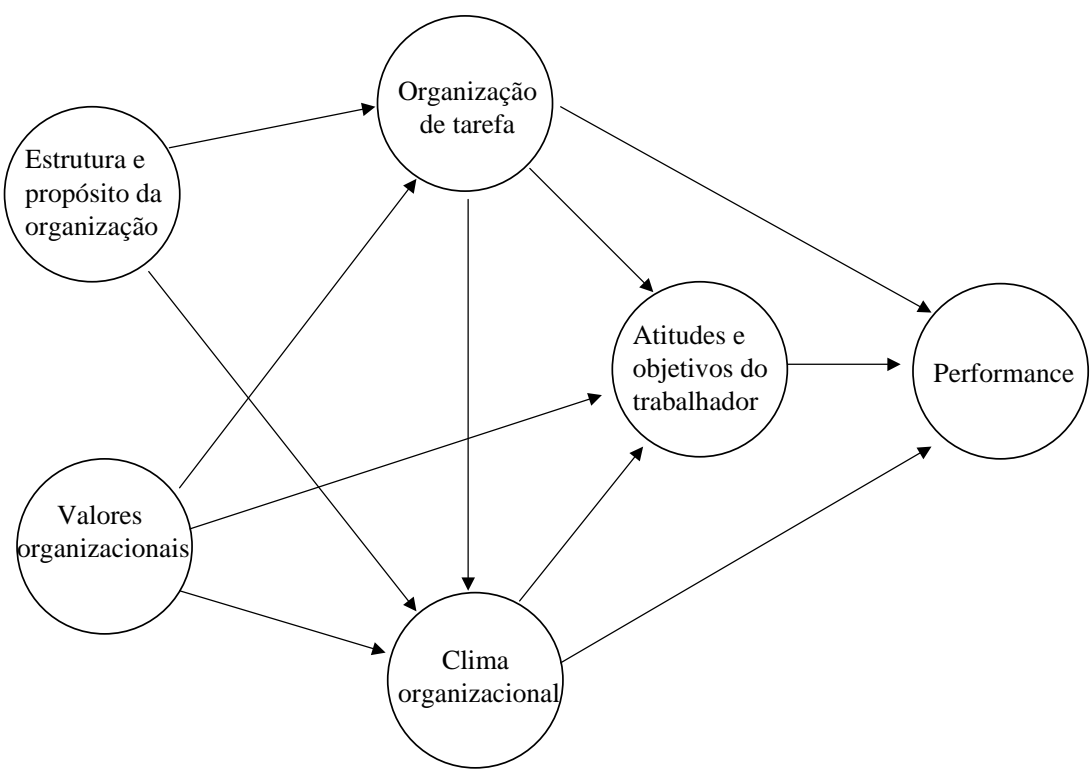

Figura 5: Modelo das variáveis que influenciam o desempenho organizacional Fonte: Adaptado Marcoulides e Heck, (1993, p. 209-225).

Gordon (1985) identificou 11 dimensões culturais que influenciam no desempenho da empresa em seu estudo empírico. A tabela a seguir apresenta as dimensões culturais e o respectivo conteúdo: 
Tabela 10: Dimensões culturais e conteúdo

\begin{tabular}{|l|l|}
\hline \multicolumn{1}{|c|}{ Dimensões Culturais } & \multicolumn{1}{c|}{ Conteúdo } \\
\hline 1. Clareza de Direção & Objetivos claros e planos compatíveis \\
\hline 2. Alcance Organizacional & Metas ousadas e inovadoras \\
\hline 3. Integração & $\begin{array}{l}\text { Operar de maneira coordenada; } \\
\text { interdependência horizontal }\end{array}$ \\
\hline 4. Contato Administração Superior & Interdependência vertical \\
\hline 5. Encorajar Iniciativa Pessoal & Liberdade de agir, inovar e assumir riscos \\
\hline 6. Resolução de Conflitos & $\begin{array}{l}\text { Encorajar discussão de conflitos e críticas } \\
\text { abertamente }\end{array}$ \\
\hline 7. Clareza de Desempenho & $\begin{array}{l}\text { Tornar claras as expectativas do desempenho } \\
\text { da companhia }\end{array}$ \\
\hline 8. Ênfase no Desempenho & $\begin{array}{l}\text { Expectativas de altos níveis de desempenho e } \\
\text { responsabilidade pessoal dos empregados em } \\
\text { atingi-los }\end{array}$ \\
\hline 9. Orientação para Ação & $\begin{array}{l}\text { Periodicidade das decisões tomadas, senso de } \\
\text { urgência para agir }\end{array}$ \\
\hline 10. Compensação & $\begin{array}{l}\text { Percepção dos empregados sobre como estão } \\
\text { sendo pagos, competitivamente e com justiça }\end{array}$ \\
\hline 11. Desenvolvimento de Recursos & $\begin{array}{l}\text { Oportunidade para crescer e desenvolver-se na } \\
\text { companhia. }\end{array}$ \\
\hline Fonte: GoRDon, G. G. The relationship of corporate culture to industry Sector and Corporate \\
Performance. 1985.
\end{tabular}

A seguir exemplos de indicadores não financeiros para medir o desempenho das empresas apresentados por Callado et al. (2008) numa pesquisa das indústrias agropecuárias: participação no mercado; evolução do número de clientes; tempo de atendimento ao cliente; rotatividade de empregados; número de reclamações; tempo para a solução de reclamações; qualidade do produto; volume de vendas; capacidade de produção; investimento em treinamento.

\subsection{7.}

\section{Indicadores híbridos de desempenho (financeiro e não financeiro)}

De acordo com Natal (2005), análise do resultado final da empresa não depende apenas de indicadores financeiros, mas sim de indicadores combinados (financeiros e não financeiros).

Dess e Robinson Jr (1984), considerados um dos primeiros os autores a analisar o desempenho sob a forma financeira e não financeira por meio de pesquisa de um modelo com métricas objetivas e subjetivas para medidas de desempenho. Esse modelo é sustentado por três pilares, sendo os dois primeiros relacionados as métricas financeiras (crescimento nas vendas e retorno total sobre ativos após as taxas) e o terceiro pilar envolve perguntas subjetivas feitas para proprietários e funcionários da empresa em questão, a 
respeito da percepção dos fatores de sucesso ou do desempenho percebido por essas pessoas.

Para Venkatraman e Ramanujam (1986) o desempenho pode ser medido por meio de três fatores: desempenho financeiro, desempenho operacional e financeiro e eficiência organizacional.

A figura abaixo ilustra o modelo proposto por Venkatraman e Ramanujam:

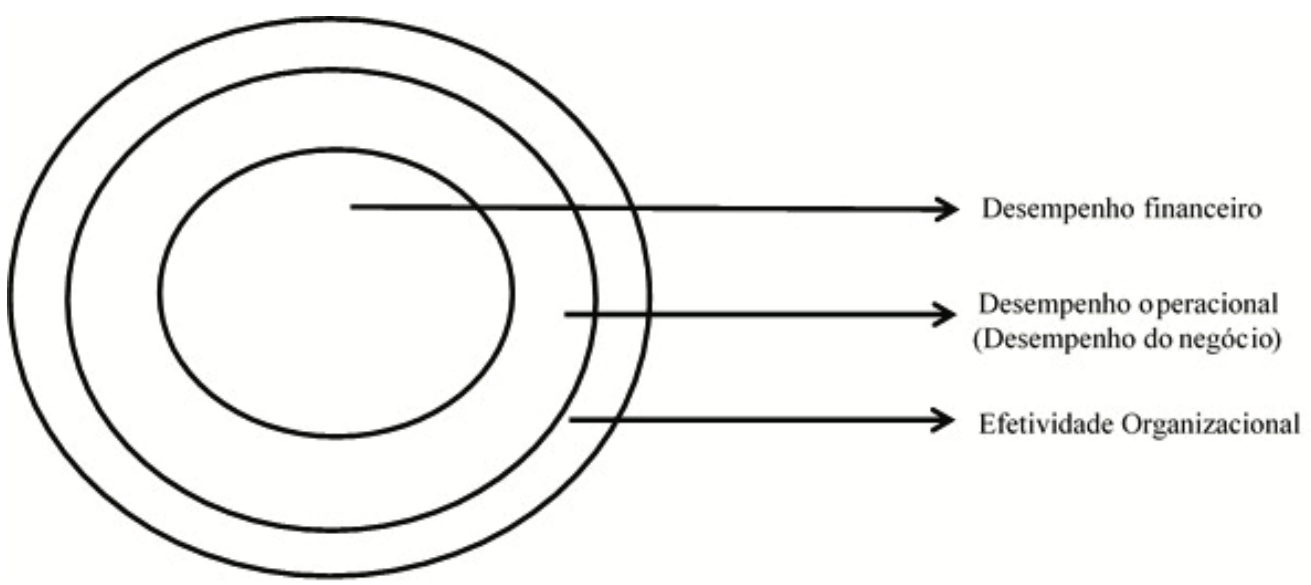

Figura 6: Modelo de desempenho de Venkatraman e Ramanujam Fonte:Adaptado de Venkatraman e Ramanujam (1986, p. 803).

Para esses autores o desempenho financeiro é atribuído as metas econômicas. Já o desempenho operacional pode viabilizado por várias maneiras. Os exemplos indicados pelos autores são: participação de mercado, introdução de novos produtos, qualidade, eficiência das ferramentas de marketing, entre outros. A efetividade organizacional que corresponde o círculo maior na imagem da Figura 6, diz respeito a soma das duas áreas menores, mais o desempenho geral da empresa.

Venkatraman e Ramanujam (1986), segregam o desempenho em operacional e financeiro, e correlacionam os dois parâmetros com os mecanismos de pesquisa do desempenho, definidos como fontes primárias e secundárias. A figura abaixo explica como essa correlação: 


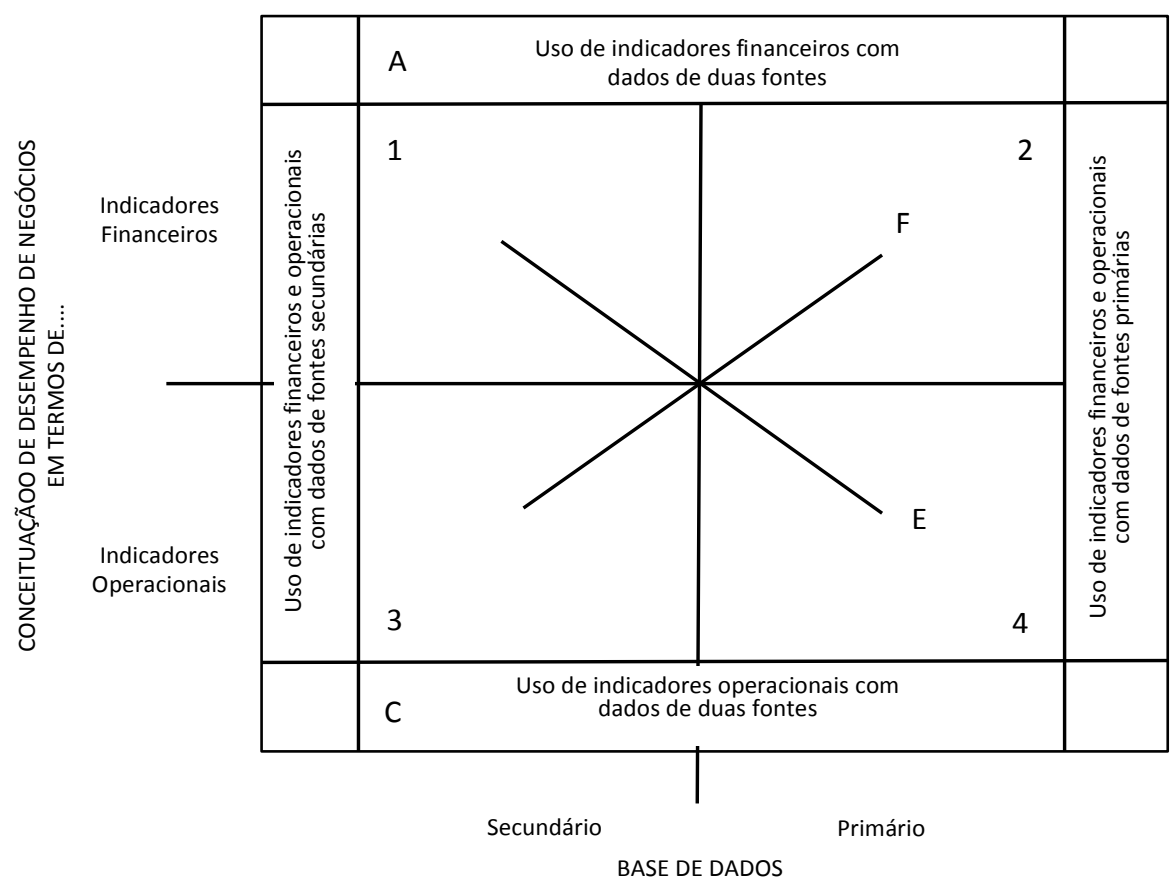

Figura 7: Correlação entre mecanismos de pesquisa do desempenho e fonte. Fonte: Adaptado de Venkatraman e Ramanujam (1986, p. 805).

Hansen e Wernerfelt (1989) por meio de um estudo com 60 empresas, aplicaram variáveis organizacionais de clima, além das financeiras para avaliar o desempenho dessas empresas. Foram utilizados a participação de mercado dessas empresas, o tamanho e o índice de lucratividade da empresa comparada a indústria que pertencia cada uma delas. Nos fatores organizacionais (ou clima organizacional) foram consideradas características como, a comunicação interna, a valorização dos recursos humanos, a forma de tomada de decisões, a organização do trabalho e a valorização do sistema de metas. A figura a seguir, apresenta o modelo de medida de desempenho de clima organizacional dos autores. 


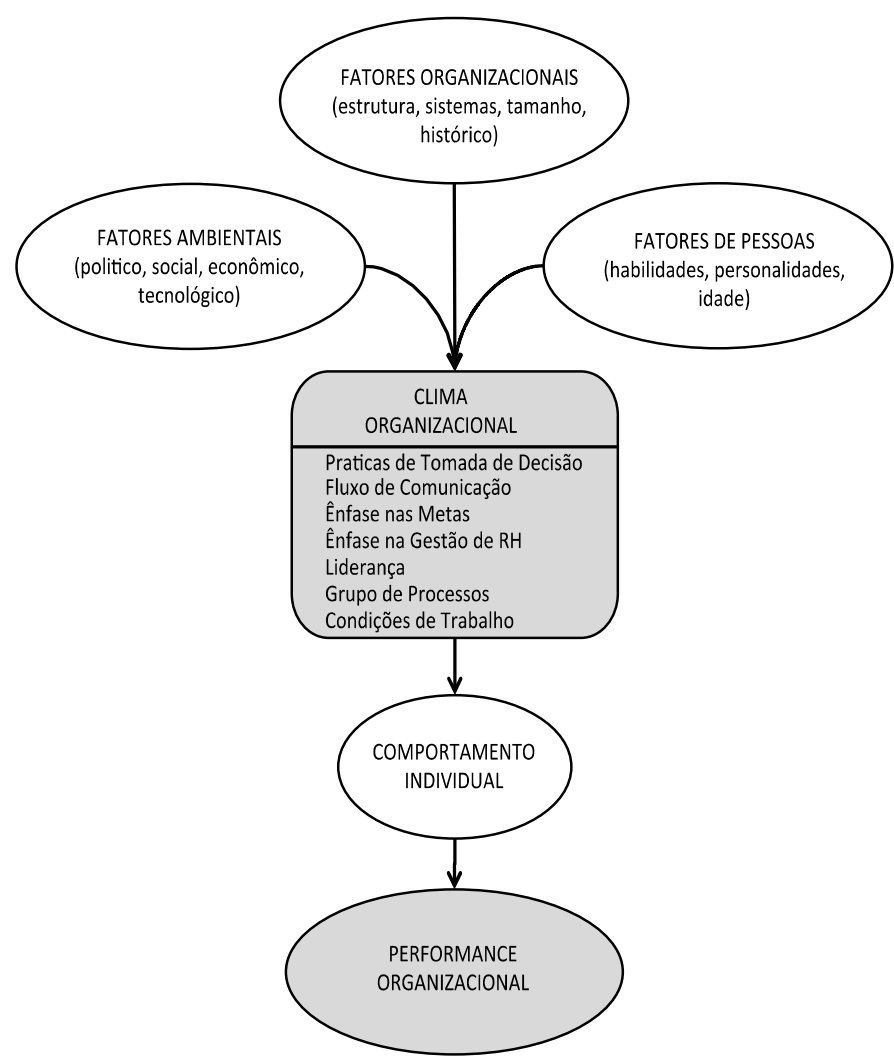

Figura 8: Modelo de desempenho de clima organizacional x variáveis econômicas. Fonte: Adaptado de Hansen e Wernerfelt (1989, p. 403).

Também foi realizada por Denison e Mishra (1995) uma pesquisa (com 34 empresas) aplicando indicadores financeiros (de Retorno sobre Investimento) e não financeiros por meio de uma matriz $2 \times 2$. Sendo utilizados os indicadores: adaptação, missão, envolvimento e consistência.

A seguir a matriz de Denison e Mishra:

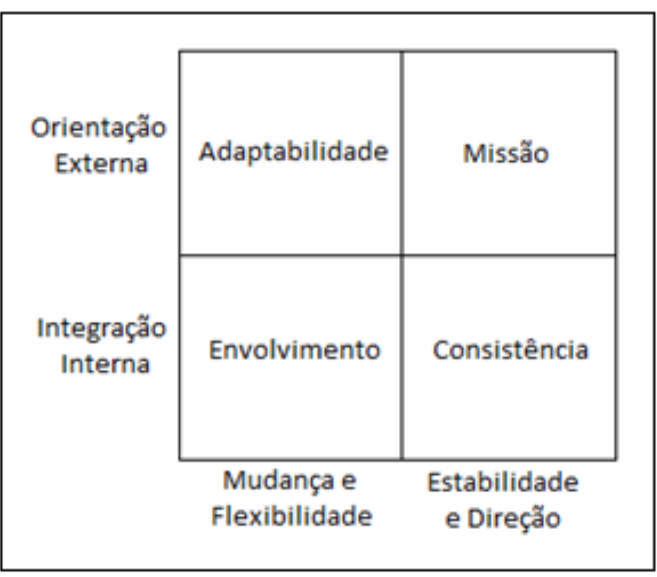

Figura 9: Modelo de cultura organizacional e efetividade. Fonte: Adaptado de Denison e Mishra (1995). 
O modelo de Denison e Mishra (1995), foi utilizado posteriormente por Fey e Denison (2003) numa nova pesquisa para avaliar o desempenho empresas na Rússia (envolvendo 179 executivos). Esse estudo contribuiu para pesquisa anterior, adicionando mais seis variáveis ao modelo apresentado na figura 9 . Sendo as seguintes: participação de mercado, crescimento nas vendas, lucratividade, satisfação dos funcionários, qualidade de produtos e serviços e o desenvolvimento de novos produtos.

Um outro modelo bem difundido para medir desempenho é o Balanced Score Card, sendo utilizado com frequência por combinar métricas financeiras com não financeiras. Para estimar o desempenho organizacional são utilizados quatro parâmetros principais. O primeiro com objetivo de explicar como os consumidores enxergam a empresa. O segundo envolve as competências internas da empresa como habilidades gerenciais, recursos humanos e desempenho operacional. A terceira fala sobre inovação e processos de aprendizagem contínua. O modelo fecha o ciclo examinando como empresa lida com seus stakeholders (KAPLAN \& NORTON, 2005). A seguir, o quadro proposto pelo modelo:

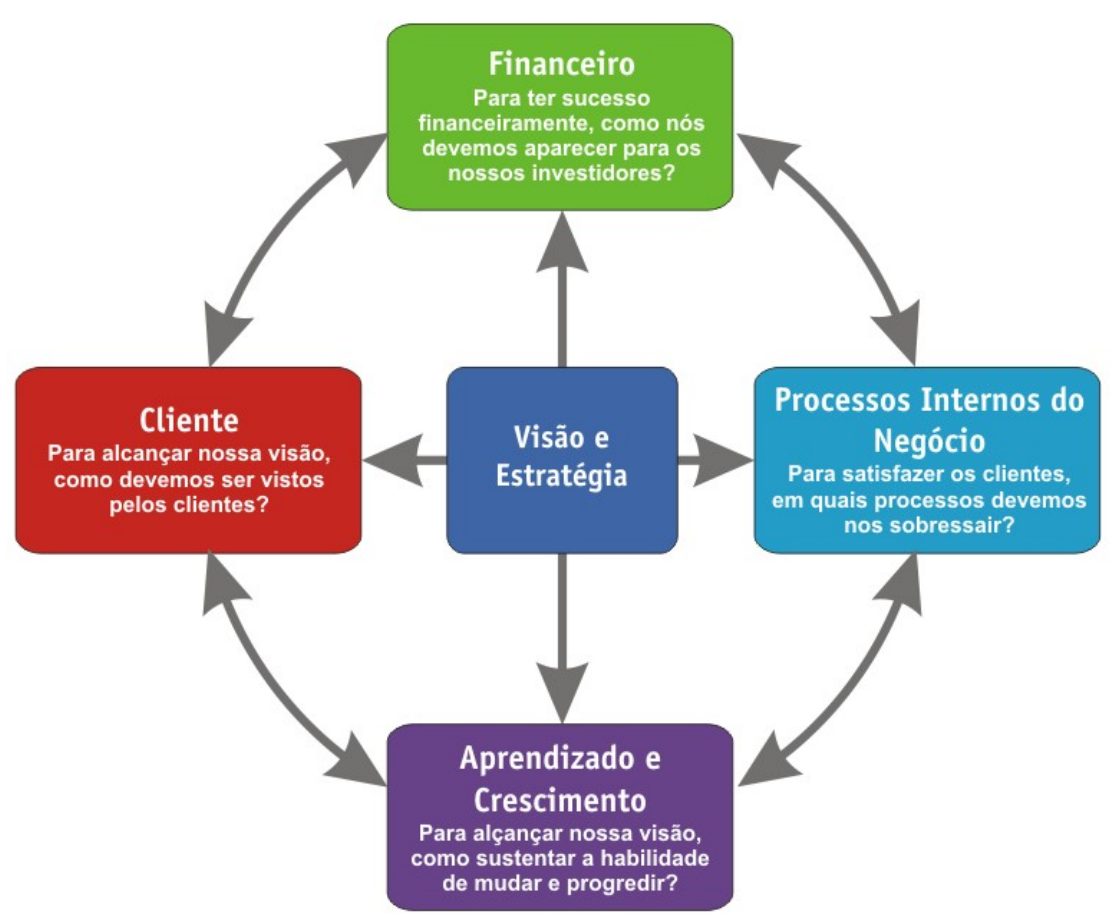

Figura 10: Balanced Scorecard.

Fonte: Adaptado de Kaplan \& Norton (2005 p.182). 
Como destacado anteriormente o objetivo dessa seção não é esgotar todos os possíveis métodos de mensurar o desempenho e sim eleger um método ou um critério, que será adaptado para conduzir a pesquisa.

\subsection{8.}

\section{Indicador de desempenho para pesquisa}

Em função do ambiente de pequenas empresas possuir uma grande influência dos líderes junto aos funcionários para se chegar ao desempenho que esse líder espera, não é suficiente analisar apenas o desempenho financeiro da empresa.

Com isso, o modelo entendido como mais adequado para medir o desempenho nesse estudo é o do Fey e Denison (2003), em que são utilizadas métricas financeiras de participação de mercado, crescimento nas vendas e lucratividade juntamente com métricas não financeiras, como a satisfação dos funcionários, a qualidade dos produtos e serviços e o desenvolvimento de novos produtos.

Assim, foi aplicada uma adaptação desse modelo para os casos envolvidos nesse estudo, considerando a divisão do desempenho das empresa em três diferentes dimensões: mercado consumidor, resultados financeiros e satisfação dos funcionários ou clima organizacional. Tendo como base o estudo feito em 2009, foi realizada nova uma análise sobre o estilo de liderança de cada um líderes tomadores de decisão das duas empresas, assim como a captura e comparação do seus respectivos indicadores de desempenho em 2015. 


\section{3 \\ Metodologia}

A metodologia de pesquisa contém processos racionais e lógicos objetivando encontrar soluções que afetam o conhecimento (DUSILEK, 1982). Este capitulo tem como objetivo apresentar os procedimentos metodológicos adotados nesse estudo. Na sequência, são informados os processos de coleta e os procedimentos de tratamento dos dados coletados. Por fim, comenta-se as possíveis repercussões que as decisões sobre como realizar o estudo impõe aos resultados obtidos.

\section{1.}

\section{Tipo de pesquisa}

Para a análise da relação entre os estilos de liderança e o desempenho organizacional três propostas metodológicas têm sido utilizadas na literatura organizacional: (a) ranqueamentos de estilos de liderança e desempenho coletados numa única fonte - nem sempre legitimando as correlações encontradas (BYCIO, HACKETT, \& ALLEN, 1995), (b) coleta de dados de fontes múltiplas (KELLER, 1992), (c) coleta de dados de múltiplas fontes e múltiplos métodos tanto para a análise da liderança quanto da mensuração do desempenho (AVOLIO, WALDMAN, \& EINSTEIN, 1988; BARLING, WEBER, \& KELLOWAY, 1996; KIRKPATRICK \& LOCKE, 1996).

Para aprofundar e contribuir para esta discussão, este trabalho utilizou múltiplas fontes e múltiplos métodos de tratamento de dados primários e secundários. Combinando uma abordagem qualitativa e quantitativa para analisar duas pequenas empresas familiares cariocas do comércio varejista, escolhidas segundo conveniência e acessibilidade.

Esse estudo, teve como referencial o trabalho realizado em 2009 por Riche, L. A Influência dos Estilos de Liderança no Desempenho da Pequena Empresa Familiar. Apresentado em sua dissertação de Mestrado em Administração da PUC-Rio.

Com o apoio de Riche, L. (2009), voltamos às duas empresas estudadas em 2009 no final do ano de 2015 e no inicio de 2016 com os seguintes objetivos: 
- resgatar os questionários respondidos em 2009;

- alinhar a interpretação do questionário de liderança aplicado em 2009 com o atual;

- identificar as mudanças significativas de cenários organizacionais e as fases do ciclo de vida das duas empresas no período 2009 e 2015/16;

- atualizar o histórico das empresas e suas características gerais (organograma, número de funcionários, área de atuação, os produtos/serviços, filiais, ...), missão, visão e valores organizacionais, estrutura organizacional, estratégia organizacional, política de Recursos Humanos, contratação, remuneração, treinamento, comunicação organizacional e processo de trabalho.

\section{2.}

\section{Seleção dos sujeitos}

Esta pesquisa envolve a análise e comparação de decisões organizacionais feitas por líderes de empresas que estejam na fase de amadurecimento dentro do ciclo de vida organizacional.Assim, os casos selecionados focaram em empresas na fase de amadurecimento segundo Greiner(1998).

Foi considerado para o ciclo de vida organizacional o modelo de cinco fases do Greiner já que esta abordagem: (i) não foi projetada apenas para pequenas ou grandes empresas, podendo ser aplicado para qualquer tipo de organização; (ii) incorpora as características dos principais modelos já pesquisados; e (iii) possui afinidade de variáveis com o propósito do trabalho na área de gestão empresarial.

Por fim, entre as abordagens disponíveis do modelo de cinco fases de Greiner (1998), foi escolhido o modelo desenvolvido por Lester, Parnell e Carraher (2003) para aplicação nesta pesquisa por levarem conta quatro fatores (tamanho da empresa, estrutura organizacional, processamento de informações e tomada de decisão).

As duas empresas selecionadas serão denominadas empresa " $A$ " e empresa "B" e tem suas principais características resumidas na tabela abaixo: 
Tabela 11: Empresas selecionadas para o estudo

\begin{tabular}{|c|c|c|}
\hline Empresa & Empresa A & Empresa B \\
\hline Setor & $\begin{array}{c}\text { Comercio Atacadista de materiais } \\
\text { compostos de alta tecnologia }\end{array}$ & $\begin{array}{l}\text { Comercio Atacadista de } \\
\text { embalagens }\end{array}$ \\
\hline $\begin{array}{c}\text { Ano de Fundação/ } \\
\text { Sede }\end{array}$ & 1992 /Rio de Janeiro & 32 \\
\hline $\begin{array}{c}\text { Número de } \\
\text { funcionários em } \\
2009\end{array}$ & 23 & 60 \\
\hline $\begin{array}{c}\text { Número de } \\
\text { funcionários em } \\
2015 / 16\end{array}$ & 63 & \\
\hline
\end{tabular}

Fonte: Elaboração Própria

\section{3.}

\section{Procedimento e instrumentos de coletas de dados}

Para a dissertação de Riche, L. (2009), os dados para a pesquisa foram coletados de fontes primárias e secundárias e incluem: documentos internos das empresas, manuais de conduta, aplicação de questionários com funcionários, e entrevistas em profundidade no qual se resgatou a historia da organização, o papel dos fundadores, sua missão, visão, valores e estratégias organizacionais.

Em 2009, foram realizadas também entrevistas semi-estruturadas que junto com os questionários aplicados tiveram como objetivo realizar um diagnóstico comportamental e analisar o desempenho organizacional.

Este questionário foi reaplicado pela pesquisadora junto com Riche para garantir a mesma abordagem metodológica, diretamente nas duas empresas no ano de 2015/16.

O pesquisador Riche fez o contato com os dois grupos empresariais, e reuniu numa mesma sala quinze funcionários da empresa $A$ e treze da empresa $B$ que possuem influência direta das lideranças. Estes questionários foram aplicados ao longo de meia hora de intervalo de expediente, e o preenchimento foi feito manualmente, sem identificação do respondente.

Este questionário é composto de duas partes com os seguintes conteúdos. (1) A primeira parte para entender o comportamento do líder das duas empresas e classificar o estilo de liderança foi elaborada a partir dos pilares de liderança situacional de Bass (1990) e com base nas questões de Pillai et al. (1999 ) e propõe 15 afirmativas para serem avaliadas em escala Likert de cinco pontos conforme detalhado na tabela abaixo: 
Tabela 12 - Afirmativas para classificação do estilo de liderança

1) Você é recompensado de acordo com o cumprimento de suas tarefas.

2) O seu chefe fica atento todo dia com os processos do dia-a-dia e toma ações corretivas quando alguma coisa não sai como ele imaginou ou quando há descumprimento das normas.

3) Seu líder só atua quando há descumprimento das regras.

4) Seu líder evita tomar decisões e se exime de responsabilidades.

5) As atitudes do seu líder fazem com que seus seguidores o respeitem.

6) Você sente orgulho de trabalhar para seu líder.

7) Seu líder encara de forma séria as necessidades pessoais dos colaboradores.

8) Ele mostra respeito pelos sentimentos individuais dos seguidores.

9) Passa por cima de seus interesses para o bem dos colaboradores.

10) Projeta uma imagem interessante do futuro para seus seguidores.

11) Promove a cooperação entre os grupos de trabalho.

12) Percebe um problema do passado como uma oportunidade de melhoria no presente.

13) Mantém a calma durante situações de crise.

14)Dá atenção individualizada para ajudar cada membro a cumprir seus objetivos, fazendo um papel de mentor ou treinador.

15) Motiva o grupo para trabalhar junto em busca do mesmo objetivo.

Fonte: Adaptado de Pillai et al. (1999).

As quatro primeiras afirmativas foram revertidas do maior para o menor, pois elas são específicas do estilo de liderança transacional enquanto as outras 11 afirmativas são oriundas do estilo de liderança transformacional. A pontuação mínima considerada foi de 15 pontos e a máxima de 75 . Em casos onde o valor ultrapassou a metade da pontuação (45 pontos) o líder foi classificado como transformacional e quando foi igual ou inferior a 45 pontos o líder foi considerado como transacional.

(2) A segunda refere-se a avaliação do desempenho da empresa pela percepção dos tomadores de decisão com base no instrumento adaptado do estudo de Fey \& Denison (2003) e inclui os seguintes itens: 
Tabela 13: avaliação do desempenho da empresa pela percepção dos tomadores de decisão

1) Mercado e Consumidor

a) Sua empresa é líder no seu mercado. Ela possui pelo menos $25 \%$ de participação de mercado na região que ela atua.

b) Os serviços oferecidos por sua empresa estão acima da média do mercado.

c) Seus clientes estão satisfeitos com o atendimento da sua empresa e preferem pagar até um pouco mais pelos seus produtos.

d) Os produtos são de boa qualidade e as queixas são poucas com relação a prazos de entrega e pagamento.

e) Sua empresa inova mais do que a maior parte das empresas do seu mercado.

2) Resultados Financeiros

a) Sua empresa tem uma boa saúde financeira. As contas são pagas em dia.

b) Nos últimos três anos você percebeu um crescimento nas vendas.

c) Os ativos, inclusive estoque, de sua empresa cresceram no mesmo período.

d) Os salários da sua empresa aumentaram em relação à média do mercado.

e) Existe uma maior delegação de poder e um aumento dos funcionários nos últimos três anos.

3) Satisfação dos Funcionários

a) Você fala para seus amigos que trabalha numa boa organização.

b) Você tem uma boa relação com seu chefe.

c) Os valores dessa empresa são parecidos com seus valores pessoais.

d) As pessoas estão comprometidas diariamente com o trabalho.

e) Você considera sua remuneração justa pelo seu nível de instrução, experiência profissional e trabalho desempenhado.

Fonte: Adaptado de Pillai et al. (1999).

Solicitou-se ao respondente, nesse caso os líderes que avaliasse numa escala Likert de cinco pontos quinze afirmativas referentes a questões que ajudassem na avaliação de desempenho em três medidas: Financeiro, Não Financeiro e Híbrido, Representados por mercado e clientes (participação do mercado, a percepção da satisfação dos clientes, a qualidade dos produtos e serviços e o poder de inovação da empresa), pelos resultados financeiros (fluxo de caixa da empresa, crescimento nas vendas, crescimento do ativo, crescimento de salários e pela percepção dos gestores, no que diz respeito à satisfação dos funcionários (quanto às tarefas exercidas, salários, e relação chefe-subordinado). 


\section{4.}

\section{Análise dos dados}

Para responder aos objetivos do estudo foram utilizadas, além de técnicas básicas de análise exploratória como média, desvio padrão, frequência absoluta e relativa, outras duas metodologias de análise estatística: o teste de exato de fisher e o teste de Mann-Withney para amostras independentes.

O teste de Wilcoxon Mann-Withney para amostras independentes foi utilizado para avaliar a associação entre variáveis categóricas e quantitativas, o teste de exato de Fisher para independência foi utilizado quando o objetivo foi avaliar a associação entre duas variáveis categóricas.

Todos os testes de hipóteses desenvolvidos nesse trabalho consideraram uma significância de $5 \%$, ou seja, a hipótese nula foi rejeitada quando p-valor foi menor ou igual a 0,05 (destacados em vermelho ao longo das tabelas na Seção II).

Detalhes técnicos sobre as metodologias utilizadas nesse trabalho são apresentados nas seções 1.1 e 1.2 .

(1.1) Teste de Wilcoxon Mann-Withney

O teste de Mann-Whitney é um teste não-paramétrico alternativo ao teste tStudent para comparar as médias de duas amostras independentes.

A única suposição necessária para a aplicação desse teste é que as duas amostras sejam independentes e aleatórias, e que as variáveis em análise sejam numéricas, contínuas ou ordinais.

A estatística teste é calculada combinando as observações das duas amostras em uma única variável de tamanho $\mathrm{N} 1+\mathrm{N} 2$, sendo identificadas as respectivas amostras. Feito isso, essa variável é ordenada (ordem crescente) e é atribuído o posto 1 à primeira observação, 2 à segunda, e assim por diante. No caso de empates, é atribuído o posto médio que essas observações teriam se não fossem empates. Em seguida, calcula-se a soma dos postos das observações de cada amostra (W1 e W2). São calculadas as quantidades:

$$
\begin{aligned}
& \mathrm{U}_{1}=\mathrm{N}_{1} \mathrm{~N}_{2}+\frac{\mathrm{N}_{2}\left(\mathrm{~N}_{2}+1\right)}{2}-\mathrm{W}_{2} \\
& \mathrm{U}_{2}=\mathrm{N}_{1} \mathrm{~N}_{2}+\frac{\mathrm{N}_{1}\left(\mathrm{~N}_{1}+1\right)}{2}-\mathrm{W}_{1}
\end{aligned}
$$


A estatística teste é:

$$
\mathrm{U}=\min \left(\mathrm{U}_{1}, \mathrm{U}_{2}\right)
$$

E a hipótese a ser testada é:

$\mathrm{HO}$ : as distribuições das duas amostras são iguais

Onde rejeitar $\mathrm{HO}$ significa que as duas amostras apresentam distribuições significativamente distintas.

\section{(1.2) Teste Exato de Fisher}

Em tabelas cruzadas $2 \times 2$, os valores esperados menores que $5 \mathrm{e}$ amostras pequenas, podem afetar a aproximação da distribuição Qui-Quadrado da estatística $X^{2}$, fazendo com que a mesma não seja suficientemente boa. Neste caso é preferível usar o teste exato de Fisher.

No teste exato de Fisher, nos baseamos no cálculo da distribuição de probabilidade das frequências da tabela. Contudo, isso não é possível na situação das tabelas com margens livres, ou com uma margem fixa e outra livre porque a probabilidade de uma dada distribuição das frequências é função de parâmetros de valor desconhecido.

Fisher (1934) propôs que a distribuição de probabilidade das frequências de qualquer um destes tipos de tabelas sejam substituídas pela probabilidade da distribuição das mesmas frequências, considerando tabelas com duas margens fixas, ou seja, uma distribuição de probabilidade hipergeométrica para a única frequência de valor livre (independente).

O teste exato de Fisher consiste na determinação desta probabilidade e dos arranjos possíveis que, com os mesmos totais marginais, tenham ainda mais desvios em relação à hipótese nula $\mathrm{H} 0$, isto é, as probabilidades de tabelas com as mesmas margens e com menores valores na entrada cujo valor, na tabela cruzada em questão, já foram consideradas baixas.

Dessa forma, se a soma $\mathrm{Pa}+\mathrm{Pa}-1+\ldots+\mathrm{P} 0$ for inferior ao nível de significância $\alpha$, devemos rejeitar a hipótese de independência. Em outras palavras, rejeitar HO significa que existe uma associação estatisticamente significativa entre as variáveis. 
3.5.

\section{Limitações do estudo (limitações do método)}

A análise longitudinal embora assegure que houve uma pequena rotatividade nas duas empresas, e possibilite que os dois grupos de respondentes sejam compostos das mesmas pessoas, especificamente a empresa $B$ teve uma rotatividade maior, o que pode distorcer a correspondência unívoca entre as duas amostras de sujeitos. O que obviamente pode mudar a percepção do dado obtido em 2009 e 2015/16, embora não invalide a pesquisa, esse fato deve ser considerado. 


\section{4}

\section{Análise e interpretação dos resultados}

Este capítulo, organizado em 2 seções, apresenta uma descrição das duas empresas e o contexto em que elas estão inseridas e suas respectivas mudanças entre o período de 2009 e 2015, assim como os principais resultados alcançados com a pesquisa realizada e as implicações em relação ao problema de pesquisa previamente selecionado.

A primeira seção apresenta e analisa as características da empresa "A ". A seção seguinte discute e analisa a empresa "B". E a terceira seção mostra os resultados e as analises comparativas entre os estudos de 2009 e 2015.

\section{1.}

A empresa (contextualização do objeto de pesquisa)

A seguir será feito um resumo da história das duas empresas, as características de cada organização, assim como do estilo do líderes e proprietários das mesmas.

\subsection{1.}

Empresa "A":

\subsection{2.}

\section{Características gerais}

A tabela a seguir apresenta as características gerais da empresa A e suas principais atualizações ou mudanças. 
Tabela 14: Características gerais da empresa A

\begin{tabular}{|c|c|c|}
\hline & $\begin{array}{c}\text { Dados Referentes } \\
\text { Ano } 2009\end{array}$ & $\begin{array}{l}\text { Atualizações } \\
\text { Ano } 2015\end{array}$ \\
\hline $\begin{array}{l}\text { Escritório Central } \\
\text { (Matriz): }\end{array}$ & $\begin{array}{l}\text { Bairro de Ipanema, Zona Sul do } \\
\text { Município do Rio de Janeiro, Estado do } \\
\text { RJ, Brasil. }\end{array}$ & Sem alterações \\
\hline Ramo: & $\begin{array}{l}\text { Comercio Atacadista de materiais } \\
\text { compostos de alta tecnologia. }\end{array}$ & Sem alterações \\
\hline $\begin{array}{l}\text { Número de } \\
\text { Funcionários: }\end{array}$ & 27 & 63 \\
\hline Atuação: & $\begin{array}{l}\text { Mercado de Barcos de Lazer, Aviação } \\
\text { Experimental e Automotiva. }\end{array}$ & $\begin{array}{l}\text { Também passou a } \\
\text { atender o ramo de } \\
\text { energia eólica. }\end{array}$ \\
\hline Porte: & $\begin{array}{l}\text { Pequena Empresa, } \\
\text { classificação do Sebrae (1999). }\end{array}$ & Sem alterações \\
\hline $\begin{array}{l}\text { Principais } \\
\text { Produtos: }\end{array}$ & $\begin{array}{l}\text { Espuma de PVC, Fibra de Vidro e } \\
\text { Resinas. }\end{array}$ & Sem alterações \\
\hline Serviços: & $\begin{array}{l}\text { Demonstração de } \text { Técnicas } \\
\text { Construção, Acompanhamento da } \\
\text { construção junto com o cliente, projeto } \\
\text { preliminar e serviços diversos de } \\
\text { engenharia. }\end{array}$ & Sem alterações \\
\hline $\begin{array}{l}\text { Almoxarifado e } \\
\text { Produção: }\end{array}$ & $\begin{array}{l}\text { Bairro de Jacarepaguá, Zona Oeste do } \\
\text { Rio de Janeiro, situado à } 30 \mathrm{KM} \text { da } \\
\text { Matriz. }\end{array}$ & Sem alterações \\
\hline $\begin{array}{l}\text { Armazém Geral } \\
\text { terceirizado } \\
\text { (Estoque 2): }\end{array}$ & $\begin{array}{l}\text { Bairro de São Cristóvão, Zona Norte do } \\
\text { Rio de Janeiro, situado à } 15 \mathrm{KM} \text { da } \\
\text { Matriz e perto das zonas portuárias } \\
(5 \mathrm{KM}) \text {. }\end{array}$ & Sem alterações \\
\hline
\end{tabular}

Fonte: Elaboração Própria

\subsection{3.}

\section{Papel do fundador}

O único sócio e fundador da empresa "A" é oriundo de uma família humilde. Seu pai era comerciante de loja em comércio popular e sua mãe cuidava da casa e dos outros cinco irmãos.

O atual sócio da empresa " $A$ " decidiu cursar engenharia naval na Universidade Federal do Rio de Janeiro (UFRJ). Foi um aluno exemplar e dedicado. Depois de se formar ele trabalhou como laminador e gerente de produção de fabricantes de barcos de lazer. Com o desejo de aprender mais dos materiais e das aplicações na construção de barcos de lazer, cursou o mestrado em materiais compostos.

Foi então que o atual sócio teve a oportunidade de conhecer um representante de uma empresa norte-americana fornecedora de Espuma de PVC que desejava introduzir esse item no mercado náutico brasileiro que tinha um enorme potencial. Foi acordada a parceria. e o sócio da empresa "A" começou a se dedicar na elaboração de projetos de embarcações de lazer que pudessem utilizar os materiais da empresa que ele trabalharia em parceria até os dias de hoje. 
Em 1986 a empresa é, informalmente fundada, na casa dos pais do sócio, onde fazia os projetos, se comunicava com seus clientes potenciais e fornecedores. A empresa não precisou de nenhum capital quando foi iniciada, mesmo porque não havia condições de se investir naquele projeto.

Usava a casa de seu irmão para armazenar as mercadorias. Essas vendas eram financiadas pela empresa norte americana até o cliente pagá-la. Com isso, não havia necessidade de investimento de capital.

Em 1992, a empresa foi montada em uma sala de 30 metros quadrados num bairro nobre da zona sul do Rio de Janeiro. Na sala trabalhavam somente três pessoas. Posteriormente foi contratado um armazém terceirizado para estocar as mercadorias.

Nos primeiros anos, a empresa funcionava na informalidade. Depois de alcançar um faturamento razoável o líder formalizou a empresa e posteriormente contratou um engenheiro para elaborar os projetos das embarcações de lazer.

Em 1995 a empresa já possuía contratos com grandes fabricantes de barcos de lazer no Brasil, e tinha seis funcionários chefiados pelo atual sócio da empresa. Nessa época, o sócio e fundador fez alguns cursos de curta duração na área de administração e gerência na Harvard Business School.

Quatro anos mais tarde o quadro era de 12 funcionários e o portfólio de clientes era de mais de 50 somente no setor náutico.

Nessa mesma época, um de seus maiores clientes ofereceu para a empresa um terreno no bairro da zona oeste do Rio de Janeiro com o intuito de sanar suas dívidas. Nesse terreno foi construído um galpão para fabricação e beneficiamento de materiais primas. Com a demanda crescente de seus materiais e necessidades maiores de beneficiamento, o galpão transformou-se em local de estoque e fábrica de matéria prima.

Já em 2004, a fábrica da zona oeste empregava mais de oito funcionários, todos sob supervisão da mesma pessoa que tomava conta do escritório central. A dificuldade de gerenciamento e a necessidade de aumentar o quadro de funcionários para atender a demanda crescente geraram uma necessidade maior de delegação de poder da empresa e afastamento do líder de algumas funções administrativas.

Esta é sua primeira e única empresa própria. Como ajudou a construir a empresa desde o início, o dono era ao mesmo tempo vendedor e engenheiro. Por meio de seu conhecimento de vendas e dos produtos ele se consolidou no mercado. 
Com o crescimento da empresa houve reorganização dos postos de trabalho e a parte administrativa foi delegada, o dono passou a dar mais ênfase em seu expertise: vender produtos técnicos.

O perfil do dono é agressivo e muitas vezes ele chega a se exaltar com as pessoas em função de atrasos ou ineficiência. Sua filosofia de trabalho é que as pessoas devem se preocupar bastante e ficar constantemente envolvidas em suas tarefas. Aparentemente ele entende que, preocupar-se é estressar-se durante o horário de trabalho. Com isso a rotina da empresa "A" está sob a pressão constante do dono. Por vezes, a autoridade com que o dono comanda as pessoas faz com que elas se sintam intimidadas.

A empresa " $A$ " teve um auge com um quadro 35 funcionários antes da crise de setembro de 2008, e em 2015 conta com 63. Alguns problemas gerenciais surgiram com a necessidade de delegação de tarefas e comando da equipe que era segmentada de acordo com o organograma (Figura13). Entretanto, as pessoas ainda entendem possuir pouca autonomia no que diz respeito a tomada de decisão, sendo a última palavra quase sempre a do dono.

\subsection{4. Missão, visão e valores organizacionais}

Para o fundador, a empresa sempre teve como meta primordial ser líder nas vendas de materiais compostos e promover o melhor serviço de engenharia para que os clientes ficassem satisfeitos e não deixassem de comprar os materiais da empresa. Os serviços de engenharia são ponto forte da empresa. A inovação em produtos, serviços e processos de construção para o cliente são fatores chaves para que a empresa continue líder de mercado na opinião do líder da empresa.

Em 2009, durante um treinamento com os principais membros da equipe, sem a presença do líder, foram discutidos vários aspectos relacionados à empresa e um deles foi a definição por meio de consenso da missão da empresa. Retirada de um documento interno da empresa, a missão para os funcionários está na tabela a seguir, juntamente com a missão declarada pelo líder e fundador. 
Tabela 15: Missão da empresa A, na opinião do líder-fundador e seus funcionários para 2009 e 2015

\begin{tabular}{|l|l|l|}
\hline Missão & Para o líder e fundador & Para os funcionários \\
\hline Ano de 2009 & Ser líder em vendas de & Atender a demanda do mercado \\
& materiais compostos e & de Composite através da \\
& promover o melhor serviço de & Distribuição de Compostos com \\
& engenharia & $\begin{array}{l}\text { preço competitivo e serviços de } \\
\text { alta tecnologia }\end{array}$ \\
\hline Ano de 2015 & Sem alterações & Sem alterações \\
\hline
\end{tabular}

Fonte: Elaboração Própria

A visão da empresa tem uma distância maior entre o que os funcionários descrevem e o líder da empresa. A tabela a seguir apresenta a visão descrita pelo líder-fundador e os funcionários:

Tabela 16: Visão da empresa A, na opinião do líder-fundador e seus funcionários em 2009 e 2015

\begin{tabular}{|l|l|l|}
\hline Visão & Para o líder e fundador & Para os funcionários \\
\hline Ano de 2009 & $\begin{array}{l}\text { Ser a empresa mais respeitada } \\
\text { no mercado de materiais } \\
\text { compostos e possivelmente ser } \\
\text { adquirida por uma grande } \\
\text { empresa. }\end{array}$ & $\begin{array}{l}\text { Ser uma empresa detentora do } \\
\text { melhor conhecimento técnico, } \\
\text { ampliando a rentabilidade das } \\
\text { nossas operações, } \\
\text { proporcionando uma melhor } \\
\text { qualidade de vida para os nossos } \\
\text { colaboradores }\end{array}$ \\
\hline Ano de 2015 & Sem alterações & Sem alterações \\
\hline
\end{tabular}

Fonte: Elaboração Própria

Os valores para o líder e fundador, estão relacionados primeiramente com o comprometimento com a empresa, seguido pelo desenvolvimento profissional, a honestidade e boas relações interpessoais.

Os valores da empresa foram definidos pelos funcionários a seguir, com sua ordenação em importância, sendo o primeiro da lista, o principal valor que a empresa deve possuir.

Tabela 17: Valores da empresa A, na opinião do líder-fundador e seus funcionários em 2009 e 2015

\begin{tabular}{|l|l|l|}
\hline Valores & Para o líder e fundador & Para os funcionários \\
\hline Ano de 2009 & Comprometimento com a & $\begin{array}{l}\text { Honestidade, Comprometimento, } \\
\text { Relacionamento Interpessoal, } \\
\text { Desenvolvimento Profissional, } \\
\text { Desenvolvimento profissional } \\
\text { Honestidade } \\
\text { Boas relações interpessoais }\end{array}$ \\
\hline Ano de 2015 & Sem alterações & Sem alterações \\
\hline
\end{tabular}

Fonte: Elaboração Própria 
O meio ambiente e as relações com a sociedade e funcionários são valores que o líder enxerga importância, porém em escala menor dos demais citados por ele anteriormente.

\subsection{5.}

\section{Estrutura organizacional}

Com o crescimento da empresa criou-se uma estrutura com vários departamentos não existentes no inicio da empresa.

As áreas de engenharia e serviços e a área de vendas e atendimento a clientes eram agrupadas no inicio. Posteriormente foi criado o departamento financeiro responsável pelo contas a pagar e a receber, além do procedimento de importação junto ao porto do Rio de Janeiro.

Do departamento de engenharia surgiu a área de desenho que fazia as apresentações dos projetos para os clientes. Nesse mesmo momento o departamento de marketing foi criado para administrar o site da empresa e sua imagem.

Somente em 2007 o dono da empresa conseguiu se desvencilhar da responsabilidade de chefia da área comercial.

Os dois últimos departamentos criados foram: de logística e transporte e o departamento de produção, em 2007. Esses com uma autonomia parcial do ponto de vista de tomada de decisão, pois muitas vezes as decisões eram condicionadas às decisões do dono da empresa.

Apesar do aumento do número de funcionários, não houve mudanças no organograma da empresa de 2009 até 2015.

A seguir o atual organograma da empresa $A$, com suas divisões funcionais: 


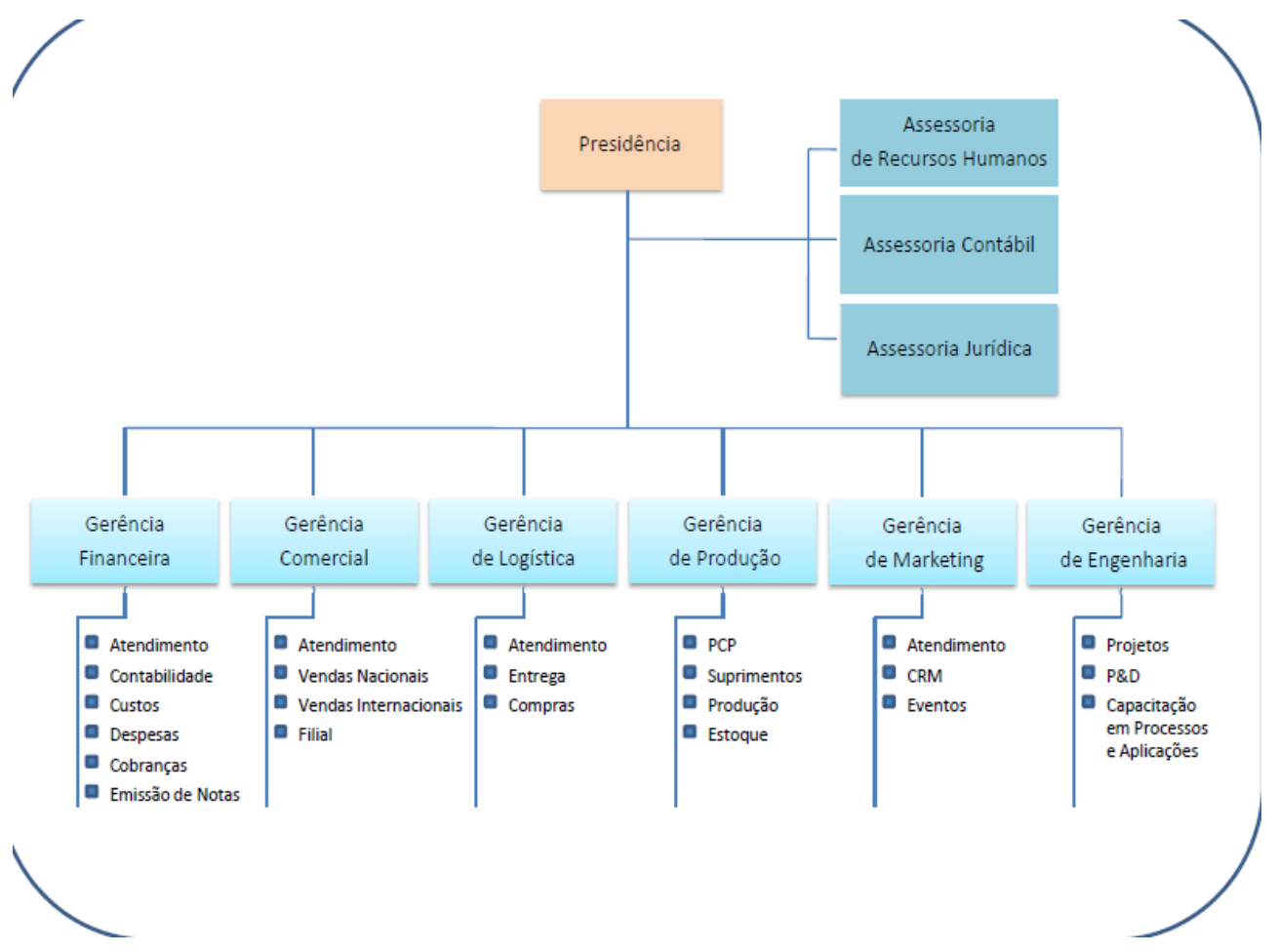

Figura 11: Organograma Empresa A

Fonte: Documentos internos da empresa.

\subsection{6.}

\section{Estratégia organizacional}

Em 2009 a empresa "A" não tinha um planejamento estratégico formal, e até 2015 não havia sido definido. Apesar de saber com clareza a estratégia da empresa, o líder não consegue transmitir ou muitas vezes não tem interesse em transmitir isso para seus funcionários. Sem horizontes, as pessoas ficam às vezes questionando o trabalho que tem a fazer. Uma frase típica dentro da empresa, dita pela equipe é: "Eu acho que é por aí, mas vai entender... A gente nunca sabe o que ele espera da gente!".

É comum que o planejamento da empresa seja baseado em função da meta mensal de vendas. O cumprimento da meta é primordial para o dono. A meta não cumprida trás a possibilidade da empresa não ser lucrativa no período.

Quando há algum evento ou demonstração para um cliente, o planejamento é feito sempre às pressas e sob o comando do líder. Mesmo nos últimos dias ou horas as pessoas não sabem ou sabem pouco sobre o que fazer durante o evento ou demonstração. 


\section{2.}

\section{Política de recursos humanos}

\subsection{1.}

\section{Contratação}

No início da empresa, as contratações eram feitas exclusivamente pelo dono. Com a divisão formal do trabalho, cada grupo ficou responsável por suas contratações. Mas a necessidade de contratação é decidida pelo dono da empresa, não havendo mudanças nesse processo até o ano de 2015.

A maior parte dos funcionários foi contratada por indicação de outras pessoas que já trabalhavam na empresa ou de outras pessoas do convívio social do dono da empresa. Raramente é avaliado o currículo e as entrevistas são em sua maioria de curta duração. Muitas vezes só há uma pessoa para a entrevista que, em geral, é aprovada para a vaga. O importante é preencher os prérequisitos esperados pelo dono da empresa.

Aprovadas pelo dono, não há conversa com o candidato aprovado para expor as regras da empresa e conversar sobre os direitos e deveres do funcionário. Sendo acordado o salário no momento inicial, o novo funcionário é designado às funções, muitas vezes sem treinamento. $O$ aprendizado acontecerá na rotina.

Demissões são raras. Somente se houver quebra em princípios defendidos pelo dono, como por exemplo, deslealdade à empresa. Com isso há uma tendência à acomodação, principalmente de funcionários não satisfeitos com o trabalho.

Alguns funcionários tem um vinculo maior com dono. $O$ mesmo tenta agradá-las e dificilmente consegue se desvencilhar, mesmo quando a performance delas não está mais adequada para empresa.

\subsection{2.}

\section{Remuneração}

A remuneração média é acima da média do mercado. Há distorções de salários dentro da empresa entre funcionários antigos e as contratações recentes. O ambiente familiar da empresa induz ao funcionário a achar que a confiança que é depositada pelo dono deveria ser fator decisivo para seu salário, ou seja, muitos ainda acreditam no fator antiguidade para serem recompensados. 
A maioria dos funcionários não possui o nível superior completo. Com a média alta de salários e a impressão de que a remuneração depende exclusivamente das funções desempenhadas e da confiança depositada pelo dono da empresa, os funcionários em geral não se sentem motivados a aumentar seu grau de instrução.

Isso somado a visão do dono com uma remuneração relativamente alta, tem como resultado períodos de salários estagnados por mais de três anos. As movimentações identificadas na pesquisa e realizadas foram os dissídios salariais.

Não há métricas de avaliação de desempenho formais dentro da empresa. Com isso os funcionários não sabem se evoluíram ou não ao longo do tempo.

A área de vendas e alguns funcionários chave da empresa recebem comissão sobre o montante recebido durante o mês. O cálculo dessa comissão é primordialmente em função da meta de vendas. Se a meta é cumprida, os funcionários recebem bônus por faixa de faturamento, caso contrário há uma penalidade. O montante final da comissão é dividido entre as pessoas que ganham comissão e essa divisão é sigilosa, apenas três pessoas tem essa informação.

\subsection{3. \\ Treinamento}

Não existe treinamentos formais quando um funcionário é admitido. O funcionário aprende em sua rotina sozinho ou quando há algum funcionário disposto a treiná-lo.

O dono da empresa, apesar de acreditar na importância do crescimento profissional dos funcionários, não oferece ajuda de custo para quem deseja fazer um curso externo. Treinamentos são pagos quando há necessidade da empresa de que o funcionário aprenda uma tarefa específica.

Antes da crise de 2008 existia um treinamento de vendas sobre os processos e produtos da empresa, que também servia para ensinar aspectos gerenciais da organização como vendas e gerenciamento de contas.

Existe uma atividade semanal, registrada em 2009 e que foi mantida até momento, em que os principais funcionários da empresa se reúnem para aprender um pouco sobre a rotina de suas respectivas áreas, sendo uma alternativa de integração e entendimento maior do cotidiano da empresa. 


\section{3.}

\section{Comunicação organizacional}

$\mathrm{Na}$ empresa "A" as pessoas que trabalham no escritório central estão próximas fisicamente, por isso usam uma comunicação mais informal e verbal. Essa forma de comunicação foi fonte de vários conflitos dentro da empresa, sendo, em geral o interlocutor da mensagem, o responsável (culpado pela outras pessoas) de não serem claros e explícitos na hora de se comunicar.

Em função de conflitos, algumas pessoas exigem a formalização da comunicação por correio eletrônico. Assim, o uso de emails ficou estabelecido até o momento dessa pesquisa como forma de registro e comunicação formal.

Além de reuniões presenciais, o rádio e o telefone são outras fontes usuais de comunicação que muitas vezes são piores que a comunicação verbal.

\section{4. Processo de trabalho}

Não há um programa formal de gerenciamento na empresa, sendo também uma fonte de conflito interno. O fluxo de trabalho e os processos acontecem por meio de planilhas de trabalho abertas à quase todos os funcionários e a falta de sincronizarão das planilhas é um complicador desse processo.

A seguir, a descrição de um exemplo do processo de fluxo de vendas, que começa pelo vendedor e termina com o controle da coleta junto a transportadora.

O vendedor anota o pedido para o cliente e verifica em planilha a disponibilidade do material em estoque. Depois das verificações, o vendedor faz o pedido em outra planilha e passa para o cliente por fax ou correio eletrônico. Esse pedido, se aprovado pelo cliente, é enviado para o departamento de logística que faz a baixa no material do inventário e imprime uma folha para o departamento que emite as notas fiscais e pede a coleta da mercadoria.

A pessoa que emite a nota fiscal faz um outro arquivo com os dados do cliente e da compra para a emissão de nota fiscal. Com a nota fiscal, a mesma pessoa pede a coleta do material e manda o processo de volta para o área de logística que entrega o processo para a separação do material e coleta das mercadorias. 


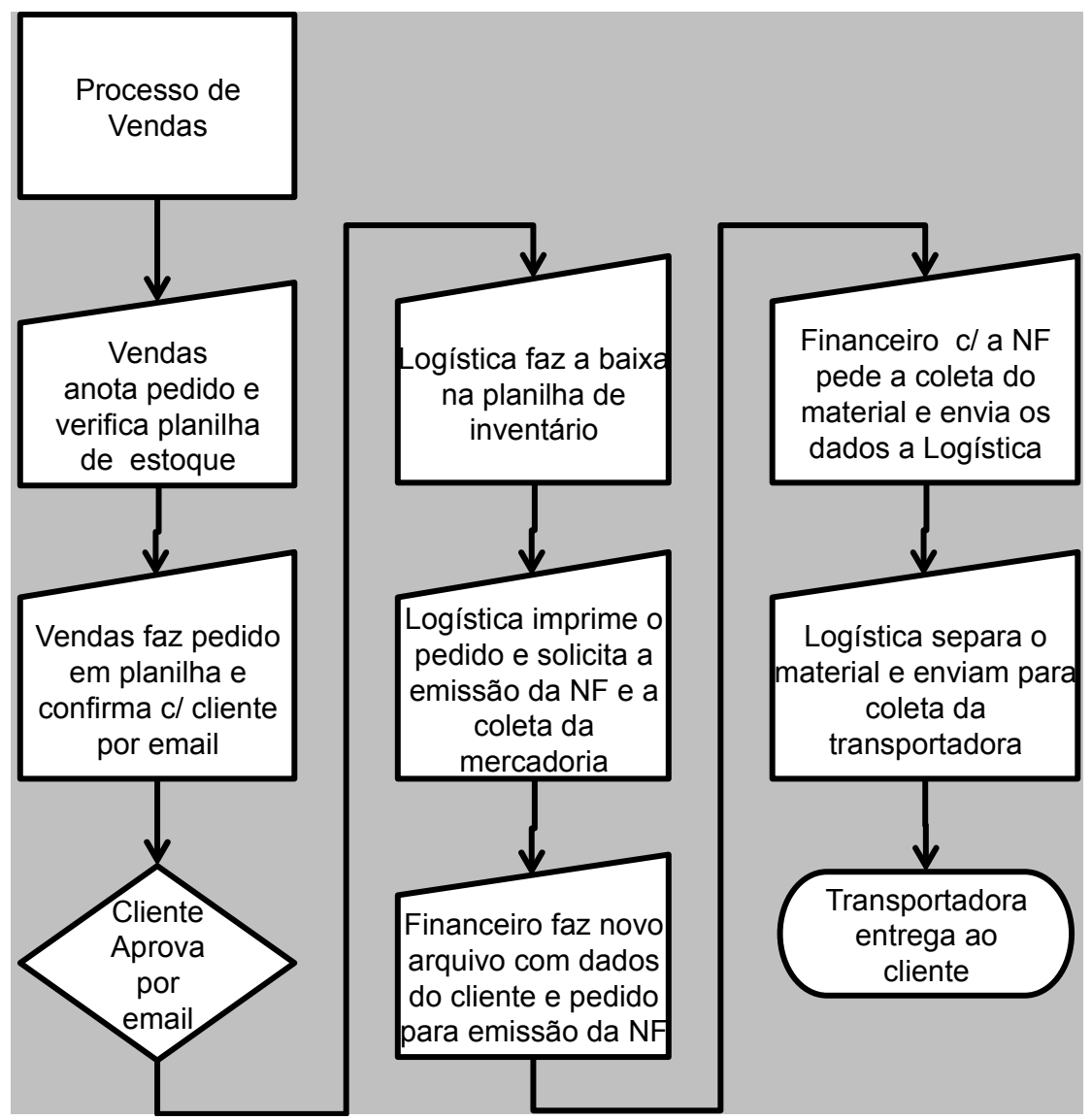

Figura 12: Exemplo de fluxo de vendas da empresa $A$.

Fonte: Adaptado de Riche, L. (2009).

Está identificado como um grande problema, por alguns funcionários, a falta de um sistema gerencial que integre todos os processos da empresa, que atualmente gera diversas falhas e erros humanos.

Os erros são severamente cobrados pelo dono,que muitas vezes fica exaltado. Mas ele não era favorável a implantação de um sistema gerencial até 2009 ,pois acreditava que primeiro as pessoas tem que errar menos para depois ser implantado um programa de gerenciamento. Mas vale destacar, que houve uma mudança nessa opinião e que está em andamento a implantação do sistema, com previsão de término em 2016.

\section{5.}

\section{Estágio de vida da Empresa "A"}

Com base na teoria do ciclo de vida da empresas de Tomei et al. (2008) foi identificado que a empresa "A" em 2009 estava próxima a fase de regulamentação e que naquele momento estava na fase expansão. Apesar da empresa ter crescimentos extraordinários nos anos de 2005 até 2008, em termos de faturamento, tinha como característica uma crise de autonomia e uma falta de profissionalismo presentes nessa empresa. 
A Empresa "A" continua apresentando um modelo com pouca delegação de poder por parte do líder. As áreas já definidas formalmente em sua estrutura têm que lidar com essa situação de fraca delegação e baixa autonomia decisória, mesmo com a pouca formalidade da rotina.

Com isso a empresa "A" passou desde ano de 2009 pela migração da fase da regulamentação para se tornar mais posicionada na fase da expansão em 2015.

Essa condição pode ter ser caracterizado em função da empresa ter sua tomada de decisão ainda muito centralizada em seu líder, ao mesmo tempo em que está estruturando e formalizando seus processos, com o plano de implementar um sistema de informações até 2016. Tudo isso visando a expansão de sua capacidade de mercado com a entrada na área eólica, além de continuar evoluindo em termos de faturamento até 2015

A tabela a seguir apresenta a identificação das fases de diferenciação do ciclo de vida organizacional. Tem com base no modelo de Greiner (1998) referenciada no capítulo 2 desse estudo, explicitando as características da empresa "A" sublinhadas, de forma a ilustrar a sua migração da fase 2 de direção ou expansão para fase 3 , de delegação ou amadurecimento. Sendo possível verificar que a maior parte dessas características estão posicionadas na fase 3. 
Tabela 18: Identificação das fases de diferenciação do ciclo de vida organizacional - empresa A

\begin{tabular}{|c|c|c|c|c|c|}
\hline & Fase 1 & Fase 2 & Fase 3 & Fase 4 & Fase 5 \\
\hline Diferenciação & Criação & Direção & Delegação & Coordenação & Reinvenção \\
\hline Foco & $\begin{array}{l}\text { Desenvolvim } \\
\text { ento de } \\
\text { Produto }\end{array}$ & $\frac{\text { Expansão da }}{\underline{\text { Capacidade }}}$ & $\begin{array}{c}\text { Eficiência } \\
\text { Operacional }\end{array}$ & Cliente e Ganhos & $\begin{array}{l}\text { Cliente e } \\
\text { Novos } \\
\text { Produtos }\end{array}$ \\
\hline Período & $\underline{\text { Imediato }}$ & $\begin{array}{l}\text { Curto Prazo - } \\
\text { Até } 3 \text { meses }\end{array}$ & $\begin{array}{c}\text { Curto Prazo } \\
3 \text { meses a } 1 \text { ano }\end{array}$ & $\begin{array}{l}\text { Médio Prazo } \\
-3 \text { anos }\end{array}$ & $\begin{array}{c}\text { Longo Prazo - } \\
5 \text { anos }\end{array}$ \\
\hline Estrutura & $\begin{array}{l}\text { Horizontal e } \\
\text { Genérica }\end{array}$ & $\frac{\text { Hierárquica e }}{\underline{\text { Funcional }}}$ & $\begin{array}{c}\text { Hierárquica e } \\
\text { Especializada } \\
\text { Descentralizada }\end{array}$ & $\begin{array}{l}\text { Baseada em } \\
\text { produto e } \\
\text { Centralizada }\end{array}$ & $\begin{array}{c}\text { Horizontal, } \\
\text { matricial e } \\
\text { mesclada/mist } \\
\text { urada }\end{array}$ \\
\hline $\begin{array}{l}\text { Estilo de } \\
\text { Comunicação }\end{array}$ & $\begin{array}{c}\text { Muito } \\
\text { informal; } \\
\text { pessoal e } \\
\text { flexível e } \\
\text { Pessoal } \\
\end{array}$ & $\frac{\frac{\text { Começa a }}{\text { emergir uma }}}{\frac{\text { formalização }}{\text { fraca }}}$ & $\begin{array}{c}\text { Formal e } \\
\text { Burocrático }\end{array}$ & $\begin{array}{c}\text { Formal e } \\
\text { Distanciada do } \\
\text { Dia-a-dia }\end{array}$ & $\begin{array}{l}\text { Mista; formal e } \\
\text { informal }\end{array}$ \\
\hline $\begin{array}{l}\text { Tipo de } \\
\text { Comunicação }\end{array}$ & $\begin{array}{c}\text { Verbal e } \\
\text { Frequente }\end{array}$ & $\begin{array}{c}\text { Verbal e } \\
\text { quando } \\
\text { necessário }\end{array}$ & $\frac{\text { Escrita; local e }}{\underline{\text { corporativa }}}$ & $\begin{array}{c}\text { Escrita; local e } \\
\text { corporativa }\end{array}$ & $\begin{array}{l}\text { Mista; local e } \\
\text { corporativa }\end{array}$ \\
\hline Decisão & $\begin{array}{l}\text { Centralizada } \\
\text { e Rápida }\end{array}$ & Centralizada & $\begin{array}{l}\frac{\text { Decentralizada }}{\text { /Dividida com }} \\
\text { outros gerentes }\end{array}$ & $\begin{array}{c}\text { Produto - } \\
\text { Decentralizada; } \\
\text { Suporte - } \\
\text { Central }\end{array}$ & $\begin{array}{c}\text { Decentralizada } \\
\text { e Rápida }\end{array}$ \\
\hline $\begin{array}{l}\text { Sistemas de } \\
\text { Controles } \\
\text { /Processos }\end{array}$ & $\begin{array}{l}\text { Raros e } \\
\text { Informais } \\
\text { Simples e } \\
\text { visual }\end{array}$ & $\begin{array}{c}\text { Em } \\
\text { Desenvolvime } \\
\text { nto } \\
\text { Simples e } \\
\text { pessoal }\end{array}$ & $\begin{array}{c}\frac{\text { Desenvolvido/ }}{\text { Básicos }} \\
\text { Sistemas de } \\
\text { controles simples }\end{array}$ & $\begin{array}{l}\text { Formal e } \\
\text { Detalhado }\end{array}$ & Simplificados \\
\hline
\end{tabular}

Fonte: Adaptado de Greiner, p. 55-67. 1998

\section{6.}

Empresa "B"

\subsection{1.}

\section{Características gerais}

A tabela a seguir apresenta as características gerais da empresa B e suas principais atualizações ou mudanças. 
Tabela 19: Características gerais - Empresa B

\begin{tabular}{|c|c|c|}
\hline & $\begin{array}{l}\text { Dados Referentes } \\
\text { Ano } 2009\end{array}$ & $\begin{array}{l}\text { Atualizações } \\
\text { Ano } 2015\end{array}$ \\
\hline $\begin{array}{l}\text { Escritório } \\
\text { Central (Matriz): }\end{array}$ & $\begin{array}{l}\text { Centro da cidade do Rio de Janeiro, Estado do } \\
\text { RJ, Brasil. Situado na Sociedade dos amigos e } \\
\text { Adjacências da Rua da Alfândega (Comércio } \\
\text { popular do SAARA) }\end{array}$ & Sem alterações \\
\hline Filial: & Situada a 200 metros do local da Matriz & $\begin{array}{l}3 \text { novas filiais, num } \\
\text { total são } 4 \text { lojas num } \\
\text { raio de } 1 \mathrm{~km}\end{array}$ \\
\hline Ramo: & Comercio Atacadista de embalagens. & \\
\hline $\begin{array}{l}\text { Número de } \\
\text { Funcionários: }\end{array}$ & 32 & $\begin{array}{l}\text { Aprox. } 60 \text { (por conta } \\
\text { da expansão) }\end{array}$ \\
\hline Atuação: & $\begin{array}{l}\text { Público em geral e comerciantes que usem } \\
\text { muita embalagem como apresentação do seu } \\
\text { produto. }\end{array}$ & Sem alterações \\
\hline Porte: & $\begin{array}{l}\text { Pequena Empresa, segundo classificação do } \\
\text { Sebrae (1999). }\end{array}$ & Sem alterações \\
\hline $\begin{array}{l}\text { Principais } \\
\text { Produtos: }\end{array}$ & $\begin{array}{l}\text { Embalagens de Papel, Embalagens de Plástico, } \\
\text { Embalagens de plástico reforçado e etc. }\end{array}$ & Sem alterações \\
\hline Serviços: & $\begin{array}{l}\text { Personalização de embalagens como sacolas } \\
\text { plásticas e bolsas de papel. }\end{array}$ & Sem alterações \\
\hline Armazém 1: & Nos fundos da Matriz. & Sem alterações \\
\hline Armazém 2: & $\begin{array}{l}\text { Em cima da Filial. Abastece as duas lojas, por } \\
\text { ser quase três vezes maior que o primeiro } \\
\text { armazém. }\end{array}$ & Sem alterações \\
\hline
\end{tabular}

Fonte: Elaboração Própria

\subsection{2.}

\section{Papel do fundador}

Filho mais novo de quatro irmãos, o dono da empresa "B" morava no centro da cidade do Rio de Janeiro, em cima da loja onde seus pais trabalhavam. Ajudava os pais desde os oito anos de idade fazendo entregas e conferindo mercadorias.

Formou-se em administração de empresas e até hoje não foi buscar seu diploma de conclusão de curso. Entende que seu aprendizado profissionalmente foi no dia-a-dia das empresas em que trabalhou e de suas leituras.

Seu primeiro emprego foi com seu Tio em uma drogaria aos 12 anos. Com 13 anos ele voltou a trabalhar com seu pai, numa organização que cresceu e chegou a possuir 36 estabelecimentos comerciais, tendo como principal atividade da empresa a distribuição. Quando tinha 14 anos, o pai se separou da sociedade com os irmãos e o dono da empresa "B" começou a tomar conta dos negócios da família, juntamente com o irmão mais velho de 18 anos. Em seguida seu pai decidiu parar de trabalhar e deixar o patrimônio de 15 lojas com seus filhos. 
Em 1991, ele e seus irmãos foram à falência após acreditar no ramo de supermercados. Depois de alguns meses, abriu uma loja de descartáveis com seus dois irmãos num imóvel do centro da cidade do Rio de Janeiro, cedido como favor de um primo deles. O negócio de descartáveis foi mantido por mais quatro anos com a compra de mais três lojas na mesma região, mas no ano de 1993, acabou rompendo a sociedade com seus irmãos.

Em meados de 1998, era proprietário de uma loja do ramo de papelaria, pouco lucrativa. Foi então que surgiu a oportunidade de se dedicar a um projeto de reestruturação das lojas e do comércio da região, chamado Projeto Saara, que interessou muito o dono da empresa "B", que vendeu a loja e se dedicou exclusivamente ao projeto.

Após quatro anos sem muito sucesso, o Projeto Saara foi se complicando. O dono da empresa "B" abriu uma loja em 2002 no ramo de embalagens de papel ao lado de uma loja de embalagens plásticas, que por coincidência era de sua irmã. Em 2003, ambos foram despejados pela prefeitura, pois o imóvel estava em situação irregular. A partir de então os dois decidiram formar uma sociedade na área de embalagens em geral, que continua até os dias de hoje.

$\mathrm{Na}$ época em que era proprietário da empresa de descartáveis surgiu a proposta de abrir um comércio de embalagens, diante da demanda identificada durante o atendimento a clientes. $O$ dono da empresa "B percebia uma carência nos lojistas de uma loja específica de embalagens. Os clientes desse produtos não conseguiam atender sua necessidade de forma consolidada e percorriam lojas de presentes, papelarias, lojas de plásticos, entre outras.., para realizar suas compras.

A união das duas lojas aumentou o fluxo de clientes. Com bons resultados, foi possível em 2006 abrir outra loja em Copacabana, bairro nobre da zona sul do Rio de Janeiro. Nesse momento foi encerrada a sociedade e o dono da empresa "B" ficou com a loja do centro e sua irmã com a de Copacabana.

Em 2008 foi comprada uma nova loja próxima a Matriz para expandir alinha de produtos da empresa. Seu filho mais velho e, posteriormente sua mulher, foram trabalhar com ele.

Segundo o dono, o papel de um comerciante é dirigir a empresa com sabedoria e passar a experiência para os filhos que vão tomar conta do patrimônio futuramente. 
Com um perfil calmo, mesmo sob estresse, o dono sempre foi paciente em resolver os problemas e justo na hora de contratar e demitir as pessoas. Ele lidera por meio da confiança e motivação, não costuma a dar broncas em seus funcionários e se orgulha de nunca ter feito isso em público. Utiliza o recurso da conversa para solucionar os erros e as situações do dia-a-dia. A equipe é motivada e segura para desempenhar bem suas funções.

Como principal sócio e fundador da empresa " $B$, o dono se encarrega de promover a maioria das reuniões de alinhamento da equipe, de acompanhar o movimento das vendas e das áreas administrativa e financeira.

A venda de embalagens é significativamente menos técnica e complexa quando comparada ao tipo de venda da empresa "A". Com isso o dono e líder dessa empresa não se envolve com a mesma intensidade na venda direta como na empresa "A".

O filho está responsável pelas área de compras, marketing e investimentos da empresa e sua mulher da administração da filial, que corresponde a aproximadamente um terço das vendas totais da empresa.

\subsection{3.}

\section{Missão, visão e valores organizacionais.}

O líder da empresa "A" entende como missão, possuir uma grande participação no mercado de embalagens do município do Rio de Janeiro. Ele tem a percepção de que sua participação de mercado já é grande.

A seguir a missão para os funcionários, juntamente com a missão declarada pelo líder e fundador.

Tabela 20: Missão da empresa B, na opinião do líder-fundador e de seus funcionários em 2009 e 2015

\begin{tabular}{|l|l|l|}
\hline Missão & Para o líder e fundador & Para os funcionários \\
\hline Ano de 2009 & Ter uma grande participação no & Dedicar-se ao máximo para a \\
& mercado de embalagens no & empresa crescer com \\
& município do Rio de Janeiro & profissionalismo e trabalho \\
\hline Ano de 2015 & Sem alterações & Sem alterações \\
\hline
\end{tabular}

Fonte: Elaboração Própria

A visão da empresa não é compartilhada pelos funcionários, somente pelo líder e fundador. 
Ele entende que a visão da empresa é ter a marca consolidada no mercado de embalagens em âmbito estadual e ter uma carteira de clientes fieis que por si só sustente a empresa. Em 2009, o dono declarou que seu sonho é fazer franquias de sua marca, mas até 2015 esse tema não teve evolução e agora existe uma vontade em aderir ao e-commerce. A tabela a seguir apresenta a visão da empresa "B".

Tabela 21: Visão da empresa B, na opinião do líder-fundador e seus funcionários em 2099 e 2015

\begin{tabular}{|l|l|ll|}
\hline Visão & Para o líder e fundador & Para os funcionários \\
\hline Ano de 2009 & Ter a marca consolidada no & Não compartilhada pelos \\
& mercado de embalagens em & funcionários. \\
& âmbito estadual e com uma & \\
& carteira de clientes fiéis que por & \\
& si só sustente a empresa e & \\
& evoluir para criação de & \\
franquias. & Sem alterações \\
\hline Ano de 2015 & Sem alterações & \\
\hline
\end{tabular}

Fonte: Elaboração Própria

Para líder e fundador, os valores percebidos consistem em ter um atendimento profissional, pontualidade e credibilidade com seus clientes e fornecedores, além de profissionalismo e compromisso com o cliente.

Já os funcionários definem como valores da empresa o profissionalismo, a honestidade, o atendimento ao consumidor e o respeito com os fornecedores e clientes. A seguir a tabela com os valores assumidos na empresa $B$.

Tabela 22: Valores da empresa B, na opinião do líder-fundador e seus funcionários em 2009 e 2015

\begin{tabular}{|l|l|l|}
\hline Valores & Para o líder e fundador & Para os funcionários \\
\hline Ano de 2009 & Atendimento profissional, & Profissionalismo, \\
& Pontualidade & Honestidade, \\
& Credibilidade com os clientes e & Atendimento ao consumidor \\
fornecedores, & $\begin{array}{l}\text { respeito com os fornecedores e } \\
\text { clientes }\end{array}$ \\
& $\begin{array}{l}\text { Profissionalismo } \\
\text { Compromisso com o cliente }\end{array}$ & Sem alterações \\
\hline Ano de 2015 & Sem alterações & \\
\hline
\end{tabular}

Fonte: Elaboração Própria

De forma geral, para os valores existe um alinhamento maior entre o líder e os funcionários da empresa $B$ do que na empresa $A$, principalmente no que diz respeito ao profissionalismo e atendimento ao cliente. 


\subsection{4.}

\section{Estrutura organizacional}

Com as características de comércio de rua e um crescimento de vendas, lento ao longo dos anos, a estrutura da empresa "B" é mais simples do que da empresa "A". Inicialmente a estrutura era composta pelos dois irmãos e funcionários com reporte direto, divididos em funções de estoquistas, embaladores, caixas e vendedores.

Pela evolução nos negócios, um gerente foi contratado para controlar a equipe, além de ser criado um setor de personalização, para o desenho e execução dos detalhes administrativos das embalagens personalizadas.

Com a entrada do filho e da mulher a sociedade passou a ser dividida em três membros da família, sendo acrescentado um subgerente na loja da Matriz.

Em 2009 havia na matriz um gerente da loja e outro para depósito. Um subgerente que servia de back-up do gerente de loja e tinha status de gerente de setor. O restante da equipe era operacional, formada por estoquistas, vendedores, caixas, porteiro e um "assistente" de faturamento. $\mathrm{Na}$ filial exista uma gerente para a supervisão da equipe que funcionava como back-up da mulher do dono, além da equipe operacional com cargos iguais ao loja da Matriz.

Não houve alterações na estrutura do organograma até 2015, somente aumento do número de funcionários. A seguir o organograma da matriz da empresa "B" e em seguida o organograma de sua filial: 


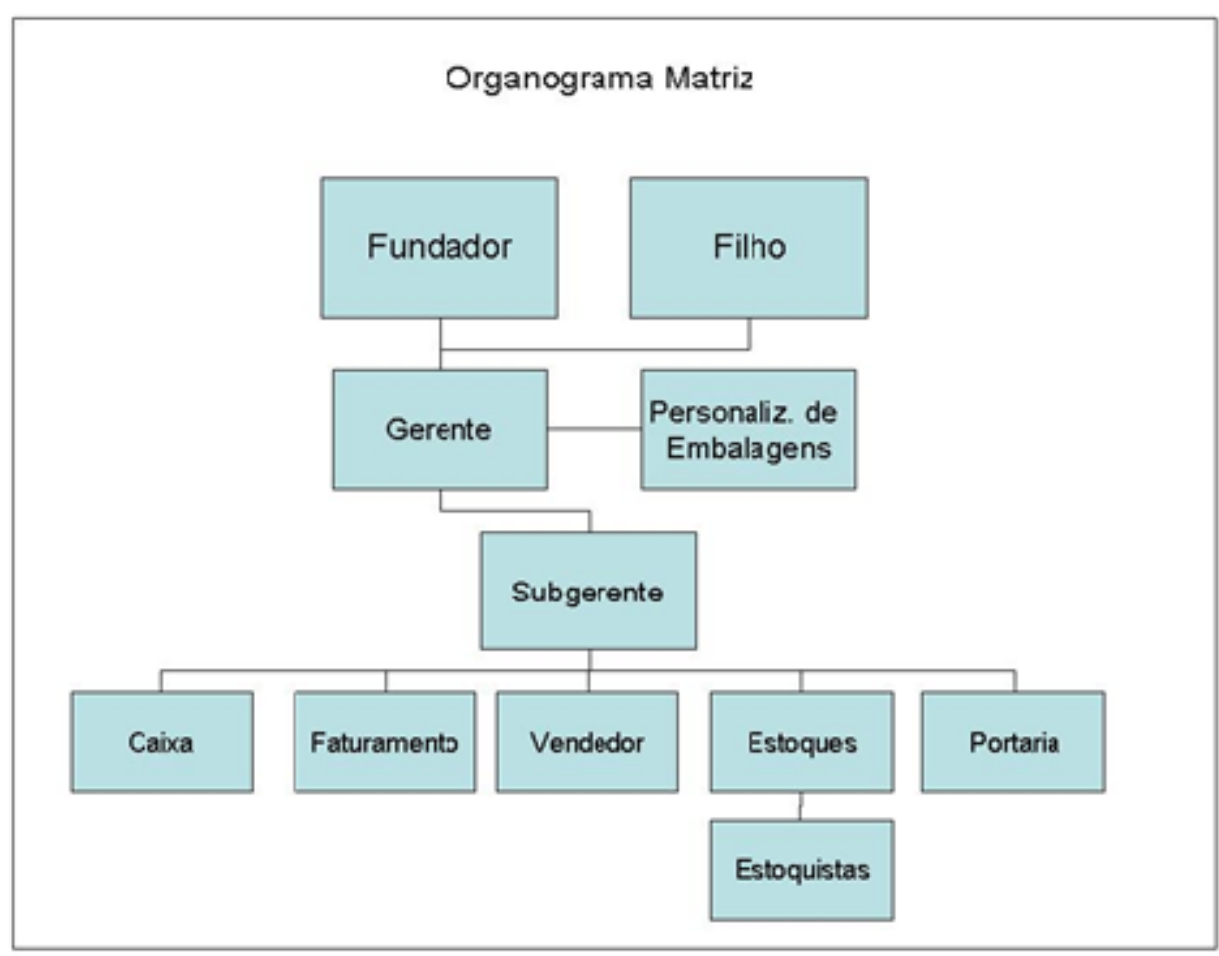

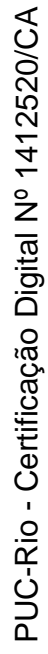

Figura 13: Organograma Empresa B (Matriz).

Fonte: Documentos internos da empresa B.

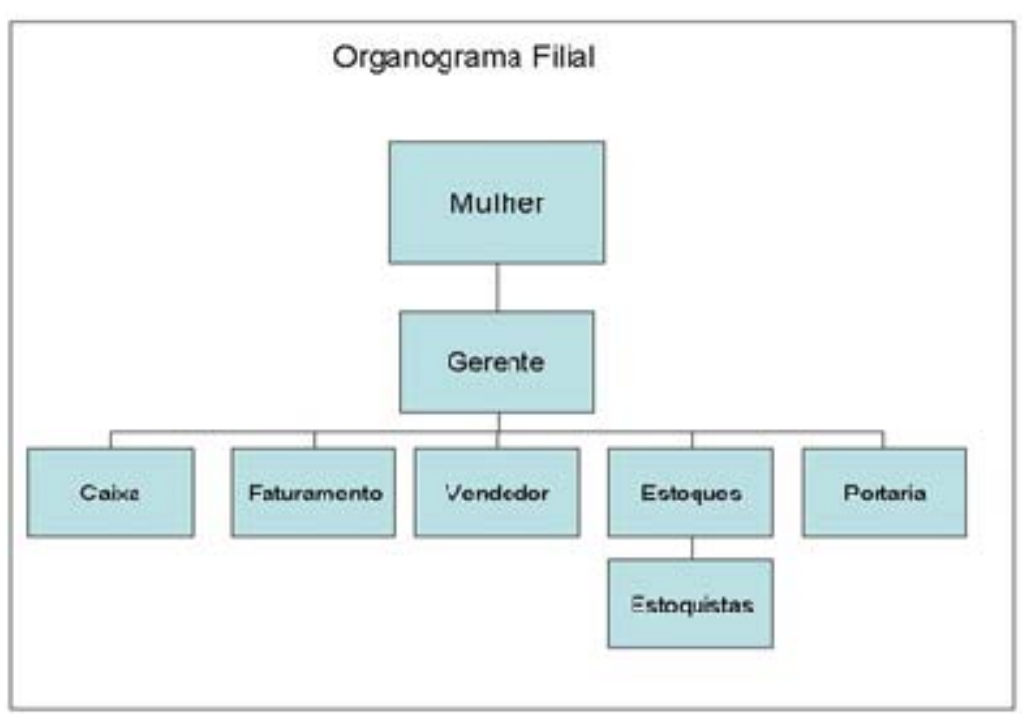

Figura 14: Organograma Empresa B (Filial). Fonte: Documentos internos da empresa B. 


\subsection{5. \\ Estratégia organizacional}

Até 2015 não há um planejamento organizacional formalizado na empresa "B", assim como na empresa "A". O dono tem como objetivo do dia-a-dia organizacional formar uma reserva de dinheiro para quitar suas dívidas de empresas anteriores e posteriormente investir mais na empresa.

Isso significa principalmente expandir, abrindo o leque de produtos, aumentando o número de lojas, comprando um carro para fazer entregas e fazendo melhorias nas lojas para atender melhor e mais rápido o cliente.

A estratégia de processos é se espelhar nas grandes e bem sucedidas empresas de comércio atacadista da região, no que diz respeito a atendimento ao consumidor e logística. Pela amizade com esses comerciantes, o dono consegue as informações, que lhe servem de benchmarking, exceto de seus concorrentes.

A estratégia de produtos é a inovação. O dono procurar desenvolver produtos novos para os clientes juntamente com os fornecedores. O dono eventualmente, fica no balcão durante o expediente para escutar as demandas dos clientes e desenvolver novos produtos com seus fornecedores.

\section{7.}

\section{Política de recursos humanos}

\subsection{1.}

\section{Contratação}

A contratação de pessoas, segue o modelo de indicação como na empresa $A$, sendo o único pré-requisito a experiência em comércio.

A responsabilidade do processo seletivo é do filho do dono, que na seleção se preocupa com a qualificação e a experiência no comércio, não sendo essencial o grau de escolaridade. No entanto é fundamental que o candidato tenha boa apresentação e desenvoltura para ser um vendedor da loja.

O processo de seleção possui alguma etapas, sendo a primeira conhecer os candidatos. Na segunda etapa os candidatos falam sobre suas qualificações e se aprovado, o candidato faz um teste de 30 dias na empresa, para avaliar suas habilidades e seu caráter.

Nessa etapa de testes, o dono da empresa explica quais são os direitos e os deveres dele, para que não haja dúvidas quanto a sua função. Também é feita uma ambientação para que ele conheça todos os setores da empresa. 
Depois de 30 dias a pessoa vai para a função designada inicialmente. Há casos em que o funcionário se adapta melhor em outro setor ou que ele começa em setores como estoque e almoxarifado para depois ser promovido a vendedor.

\subsection{2.}

\section{Remuneração}

O dono tem uma frase que identifica um pouco sua opinião sobre remuneração. "Salário é igual aluguel: é pouco pra quem recebe e é muito para quem paga."

O piso salarial do comerciário é a base dos salários da empresa "B", e para se diferenciar no mercado o dono da empresa prefere pagar um pouco a mais do que piso, além de entender que isso melhora a satisfação de equipe. Existe bonificação de vendas para produtos como personalização de sacolas plásticas e de papel, em que a margem de lucro é maior.

Os gerentes e os subgerentes tem uma faixa salarial maior pela função, tempo de casa, mérito e experiência. Esse modelo não teve mudanças de 2009 a 2015.

\subsection{3. \\ Treinamento}

Com o mesmo modelo de treinamento de 2009 a empresa até 2015 não paga cursos externos, a não ser com interesse específico. Como cursos internos são considerados a ambientação na entrada da empresa e o treinamento realizado pelo sócios sobre como se portar na frente de um cliente. Eles também conversam com a equipe para compartilhar a cultura da empresa, que valoriza a excelência no atendimento ao consumidor.

Os funcionários mais antigos também são instruídos para fazer a transferência do conhecimento no dia-a-dia.

Mesmo com a baixa complexidade das atividades, treinar pessoas numa empresa de comércio não é vista como fácil, na visão dos sócio da empresa "B". Trata-se de uma atividade importante na empresa e eles estão comprometidos com a manutenção do bom atendimento. 


\section{8.}

\section{Comunicação organizacional}

A empresa B mantém em 2015 cerca de 90\% de sua comunicação como verbal. Raramente há uma advertência por escrito ou uma circular para os funcionários. Para o dono a comunicação é muito informal e gera pouco ruído em função do tamanho da equipe e da confiança que ele transmite para seus funcionários. Se ocorrer problemas com a comunicação o dono procura resolvelos no final do dia. Se depois dessa ação os problemas persistirem por escolha do funcionário em insistir em falhar ele é demitido.

Existe uma rotina de reuniões bimestrais e eventualmente reuniões extraordinárias para a equipe expor suas dúvidas ou para compartilhar melhorias nos processos. As reuniões são participativas e as opiniões são anotadas pelo próprio dono, que controla semanalmente as ações de melhorias acordadas para serem implantadas.

\section{9.}

\section{Processo de trabalho}

O processo de trabalho é informatizado por meio de um sistema de controle gerencial, que é mantido desde de sua implementação, sem mudanças até 2015. Não há queixas quanto a utilização do sistema. Em geral, as pessoas operam bem o sistema devido a sua simplicidade.

Os vendedores não usam o sistema, somente caixas e gerentes que tem acesso ao sistema informatizado. Isso reduz o número de pessoas que precisam operar o sistema e facilita o andamento da operação.

O sistema usa como base das transações o código de barras. O cliente escolhe a mercadoria, paga no caixa e nesse mesmo local retira a mercadoria. Se forem grandes quantidades, é atendido por um gerente ou subgerente que pede a mercadoria ao almoxarifado e emite a nota em outro local para que o cliente vá direto ao caixa com a nota da pré-venda, pagando e retirando sua mercadoria com a gerência.

\subsection{0.}

\section{Estágio de vida da Empresa "B"}

Em 2009, diferentemente da empresa "A", a empresa "B" ainda vivia sua etapa de Expansão, de acordo com Tomei et al. (2008). Nesse momento o dono da empresa acreditava no crescimento dos negócios e consequentemente da estrutura, mas não se encontrava na fase de regulamentação ainda, pois o líder conseguia administrar o negócio do tamanho que estava. 
Também foi identificado que com a entrada do filho e da mulher, a empresa "B" começou a viver um momento na qual a delegação de poder passou a ser fundamental para que a empresa crescesse, pois a concentração das tarefas operacionais e decisórias nas mãos somente do líder poderia limitar seu crescimento.

Em 2015, a empresa "B" já consegue ter características que a posiciona na fase 3 de delegação ou amadurecimento, com base no modelo de 5 fases de Greiner, (1998). A tomada de decisão teve um movimento maior de descentralização com as novas filiais. Tanto para os sócios, quanto para uma estrutura que contava com gerentes nas 4 lojas para as decisões operacionais de rotina, já que os 3 sócios não podiam estar em todas as 4 unidades em tempo integral.

A diferenciação dos papéis ainda continua, com a liderança concentrandose também numa gestão maior do ambiente externo, principalmente em relação aos clientes.

Durante a Fase 3, a concorrência atua no mercado de uma forma significativa e o crescimento do mercado começa a diminuir, colocando pressão adicional e atenção em possíveis melhorias nas finanças. Nessa empresa, o dono já enxergava uma expectativa de crescimento não acontecendo como esperado, como por exemplo as vendas que em 2015 estão estagnadas e não crescendo $10 \%$, conforme almejado.

$\mathrm{Na}$ tabela a seguir que apresenta a identificação das fases de diferenciação do ciclo de vida organizacional, com base no modelo de Greiner (1998), é possível identificar as características da empresa "B" sublinhadas, que fazem parte da fase 3 , de delegação ou amadurecimento. Mesmo com características das fases 2 de direção ou expansão e fase 1 de criação ou pioneira, observa-se que a maior parte dessas características estão na posicionadas na fase 3 . 
Tabela 23: Identificação das fases de diferenciação do ciclo de vida organizacional - Empresa B

\begin{tabular}{|c|c|c|c|c|c|}
\hline & Fase 1 & Fase 2 & Fase 3 & Fase 4 & Fase 5 \\
\hline Diferenciação & Criação & Direção & Delegação & Coordenação & Reinvenção \\
\hline Foco & $\begin{array}{c}\text { Desenvolvi } \\
\text { mento de } \\
\text { Produto }\end{array}$ & $\frac{\text { Expansão da }}{\underline{\text { Capacidade }}}$ & $\begin{array}{l}\text { Eficiência } \\
\text { Operacional }\end{array}$ & $\begin{array}{l}\text { Cliente e } \\
\text { Ganhos }\end{array}$ & $\begin{array}{c}\text { Cliente e } \\
\text { Novos } \\
\text { Produtos }\end{array}$ \\
\hline Período & Imediato & $\begin{array}{l}\text { Curto Prazo - } \\
\text { Até } 3 \text { meses }\end{array}$ & $3 \underline{\text { Curto Prazo }}$ & $\begin{array}{c}\text { Médio Prazo } \\
-3 \text { anos } \\
\end{array}$ & $\begin{array}{c}\text { Longo Prazo - } \\
5 \text { anos }\end{array}$ \\
\hline Estrutura & $\begin{array}{c}\text { Horizontal e } \\
\text { Genérica }\end{array}$ & $\frac{\text { Hierárquica e }}{\text { Funcional }}$ & $\begin{array}{l}\text { Hierárquica e } \\
\text { Especializada } \\
\text { Descentralizada }\end{array}$ & $\begin{array}{l}\text { Baseada em } \\
\text { produto e } \\
\text { Centralizada }\end{array}$ & $\begin{array}{c}\text { Horizontal, } \\
\text { matricial e } \\
\text { mesclada/mis } \\
\text { turada }\end{array}$ \\
\hline $\begin{array}{l}\text { Estilo de } \\
\text { Comunicação }\end{array}$ & $\frac{\frac{\text { Muito }}{\text { informal; }}}{\frac{\text { pessoal e }}{\text { flexível e }}}$ & $\begin{array}{c}\text { Começa a } \\
\text { emergir uma } \\
\text { formalização } \\
\text { fraca }\end{array}$ & $\begin{array}{c}\text { Formal e } \\
\text { Burocrático }\end{array}$ & $\begin{array}{c}\text { Formal e } \\
\text { Distanciada } \\
\text { do Dia-a-dia }\end{array}$ & $\begin{array}{l}\text { Mista; formal } \\
\text { e informal }\end{array}$ \\
\hline $\begin{array}{l}\text { Tipo de } \\
\text { Comunicação }\end{array}$ & $\begin{array}{l}\text { Verbal e } \\
\text { Frequente }\end{array}$ & $\begin{array}{c}\frac{\text { Verbal e }}{\text { quando }} \\
\text { necessário }\end{array}$ & $\begin{array}{l}\text { Escrita; local e } \\
\text { corporativa }\end{array}$ & $\begin{array}{l}\text { Escrita; local e } \\
\text { corporativa }\end{array}$ & $\begin{array}{c}\text { Mista; local e } \\
\text { corporativa }\end{array}$ \\
\hline Decisão & $\begin{array}{l}\text { Centralizad } \\
\text { a e Rápida }\end{array}$ & Centralizada & $\begin{array}{l}\frac{\text { Decentralizada }}{\text { /Dividida com }} \\
\text { outros gerentes }\end{array}$ & $\begin{array}{c}\text { Produto - } \\
\text { Decentralizad } \\
\text { a; Suporte - } \\
\text { Central }\end{array}$ & $\begin{array}{c}\text { Decentralizad } \\
\text { a e Rápida }\end{array}$ \\
\hline $\begin{array}{l}\text { Sistemas de } \\
\text { Controles } \\
\text { /Processos }\end{array}$ & $\begin{array}{l}\text { Raros e } \\
\text { Informais } \\
\text { Simples e } \\
\text { visual }\end{array}$ & $\begin{array}{c}\text { Em } \\
\text { Desenvolvim } \\
\text { ento } \\
\text { Simples e } \\
\text { pessoal }\end{array}$ & $\begin{array}{c}\frac{\text { Desenvolvido/ }}{\text { Básicos }} \\
\frac{\text { Sistemas de }}{\frac{\text { controles }}{\text { simples }}}\end{array}$ & $\begin{array}{l}\text { Formal e } \\
\text { Detalhado }\end{array}$ & Simplificados \\
\hline
\end{tabular}

Fonte: Adaptado de Greiner, p. 55-67. 1998.

\subsection{1. \\ Descrição dos resultados}

Essa seção pretende analisar os resultados dos questionários respondidos em 2015, comparando-os com o diagnóstico feito em 2009. Para tal serão seguidos os mesmos passos do estudo realizado em 2009.

Primeiramente será analisado o estilo de liderança dos dois líderes das empresas em análise. O questionário aplicado em sua primeira parte visa classificar a liderança conforme as teorias situacionais de liderança de Bass (1990).

Para isso será considerado como um estilo transacional a média dos resultados até 45 pontos e classificado com um estilo transformacional a média das respostas que ultrapassarem 45 pontos, ou seja, acima dos 45 pontos.

A avaliação do desempenho das empresas são tratadas na segunda parte do questionário. A metodologia foi adaptada do estudo de Fey \& Denison (2003), sendo apresentado o que os respondentes consideram sobre o desempenho de mercado da empresa, tratando-se de afirmativas genéricas sobre participação de mercado e percepção de satisfação do consumidor quanto a produtos e serviços. 
Em seguida será abordada a percepção do desempenho financeiro da empresa pelos respondentes. Os itens abordados foram: crescimento dos ativos da empresa, a saúde financeira da empresa e o crescimento em suas vendas.

Por último, foram analisadas as percepção dos gestores no que diz respeito à satisfação dos funcionários (quanto às tarefas exercidas, salários e a relação chefe-subordinado).

\subsection{1.}

\section{Estilos de liderança}

Esse item apresenta os resultados do estilo de liderança de cada um dos líderes.

A análise estatística apresentada neste trabalho refere-se aos dados coletados a partir da aplicação do questionários em amostra de funcionário das empresas A e B nos anos de 2009 e 2015/16.

A análise iniciou-se com a descrição das empresas quanto ao \% de cada tipo de liderança em cada ano de análise. Para a Empresa $A$ observamos que em 2009 o tipo de liderança transacional representava $81 \%$ da amostra subindo para $100 \%$ em 2015 , já o estilo transformacional caiu de $19 \%$ para $0 \%$. Observamos através do teste exato de Fisher que esta diferença entre os anos não é estatisticamente significativa uma vez que o $p$-valor foi superior a 0.05 ( $p$ valor 0.2258).

Para a empresa B observamos um estilo diferente com maior peso da liderança transformacional que representava 92\% das respostas no ano de 2009 e $100 \%$ das respostas no ano de 2015 . Através do teste exato de Fisher vemos que esta diferença entre os anos não é estatisticamente significativa, uma vez que o $p$-valor foi superior a 0.05 ( $p$-valor 0.4800 ).

Avaliando a última linha da Tabela 23 temos a comparação entre as empresas em cada ano (2009 e 2015). Observamos que os p-valores para ambos os anos são menores do que 0.05 (p-valores <0.0001), ou seja, podemos afirmar que o estilo de liderança é estatisticamente diferente entre as empresas, sendo que a empresa $A$ tem um estilo transacional e a empresa $B$ um estilo transformacional. 
Tabela 24 - Frequência absoluta e \% coluna para avaliação da proporção de cada tipo de liderança nos anos de 2009 e 2015 em cada empresa analisada, seguido do p-valor teste exato de Fisher para comparação entre os anos de uma mesma empresa e para comparação entre as empresa em um mesmo ano

\begin{tabular}{|c|c|c|c|c|c|c|}
\hline \multirow{2}{*}{ Empresa } & \multirow{2}{*}{ Tipo de liderança } & \multirow{2}{*}{ Estatística } & \multicolumn{2}{|c|}{ Ano } & \multirow{2}{*}{ Total } & \multirow{2}{*}{$\begin{array}{c}\mathrm{p} \text {-valor } \\
\text { (comparação } \\
\text { entre os anos) }\end{array}$} \\
\hline & & & 2009 & $2015 / 16$ & & \\
\hline $\begin{array}{c}\text { Empresa } \\
\mathrm{A}\end{array}$ & $\begin{array}{c}\text { Transacional } \\
\text { Transformacional }\end{array}$ & $\begin{array}{c}\mathrm{N} \\
\% \text { coluna } \\
\mathrm{N} \\
\% \text { coluna }\end{array}$ & $\begin{array}{c}13 \\
81 \\
3 \\
19\end{array}$ & $\begin{array}{c}15 \\
100 \\
0 \\
0\end{array}$ & 28 & 0.2258 \\
\hline $\begin{array}{c}\text { Empresa } \\
\mathrm{B}\end{array}$ & $\begin{array}{c}\text { Transacional } \\
\text { Transformacional }\end{array}$ & $\begin{array}{c}\mathrm{N} \\
\% \text { coluna } \\
\mathrm{N} \\
\% \text { coluna }\end{array}$ & $\begin{array}{c}1 \\
8 \\
11 \\
92\end{array}$ & $\begin{array}{c}0 \\
0 \\
13 \\
100\end{array}$ & 24 & 0.4800 \\
\hline $\begin{array}{l}\text { p-valor } \\
\text { empresas }\end{array}$ & (Comparação entr & & $<0.0001$ & $<0.0001$ & & \\
\hline
\end{tabular}

Fonte: Elaboração própria

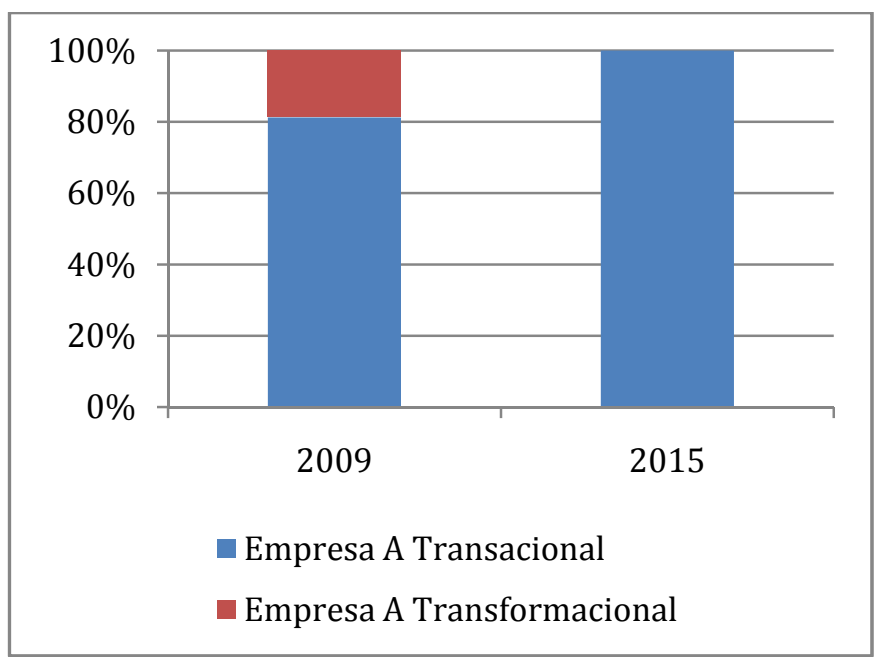

Figura 15 - Gráfico com as respostas de 2009 e 2015 do questionário de estilos de liderançaempresa A

Fonte: Elaboração própria 


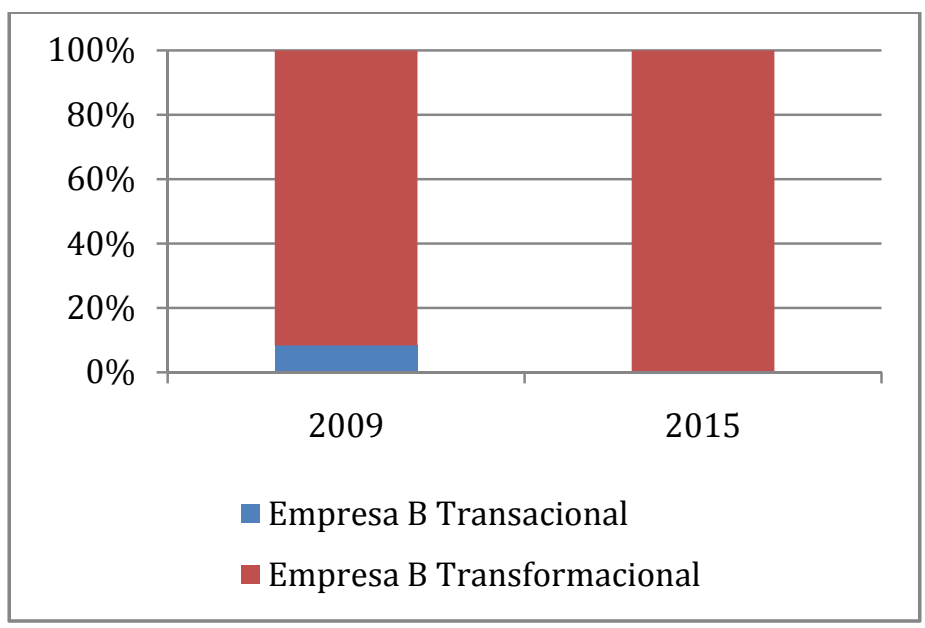

Figura 16 - Gráfico com as respostas de 2009 e 2015 do questionário de estilos de liderançaempresa B

Fonte: Elaboração própria

Posteriormente foi desenvolvido o mesmo tipo de análise porém considerando agora a pontuação (escore) nas questões de 1 a 15. Neste caso, o teste considerado foi o teste de Mann-Whitney não paramétrico.

Observamos para a empresa $A$ que a pontuação média no escore de liderança caiu de 38.3 para 34.6 , sendo esta queda estatisticamente significativa uma vez que o $p$-valor foi inferior a 0.05 ( $p$-valor 0.0406). Já não podemos dizer que houve alguma diferença entre os anos para a empresa $B$ uma vez que o $p$ valor do teste foi superior a 0.05 . Comparando entre as empresas dentro de um mesmo ano (ultima linha da tabela), foi possível identificar ( $p$-valor $<0.0001 \mathrm{em}$ ambos os casos) que as empresas são diferentes quanto a pontuação de liderança, sendo que a Empresa A apresentou menor pontuação do que a empresa B em ambos os anos.

Tabela 25 - Média e desvio padrão do escore de liderança de cada empresa por ano, p-valor do teste Mann-Whitney para comparação entre anos de uma mesma empresa e entre empresas em um mesmo ano

\begin{tabular}{|c|c|c|c|c|c|}
\hline \multirow{3}{*}{ Empresa } & \multicolumn{4}{|c|}{ Ano } & \multirow{3}{*}{$\begin{array}{c}\text { p-valor } \\
\text { (comparação } \\
\text { entre anos) }\end{array}$} \\
\hline & \multicolumn{2}{|c|}{2009} & \multicolumn{2}{|c|}{2015} & \\
\hline & Média & $\begin{array}{l}\text { Desvio } \\
\text { padrão }\end{array}$ & Média & $\begin{array}{l}\text { Desvio } \\
\text { padrão }\end{array}$ & \\
\hline Empresa A & 38.3 & 5.7 & 34.6 & 2.4 & 0.0406 \\
\hline Empresa B & 55.9 & 7.4 & 54.9 & 3.6 & 0.3630 \\
\hline $\begin{array}{c}\mathrm{p} \text {-valor } \\
\text { (comparação } \\
\text { entre empresas) }\end{array}$ & & $<0.0001$ & & 0.0001 & \\
\hline
\end{tabular}

Fonte: Elaboração própria 


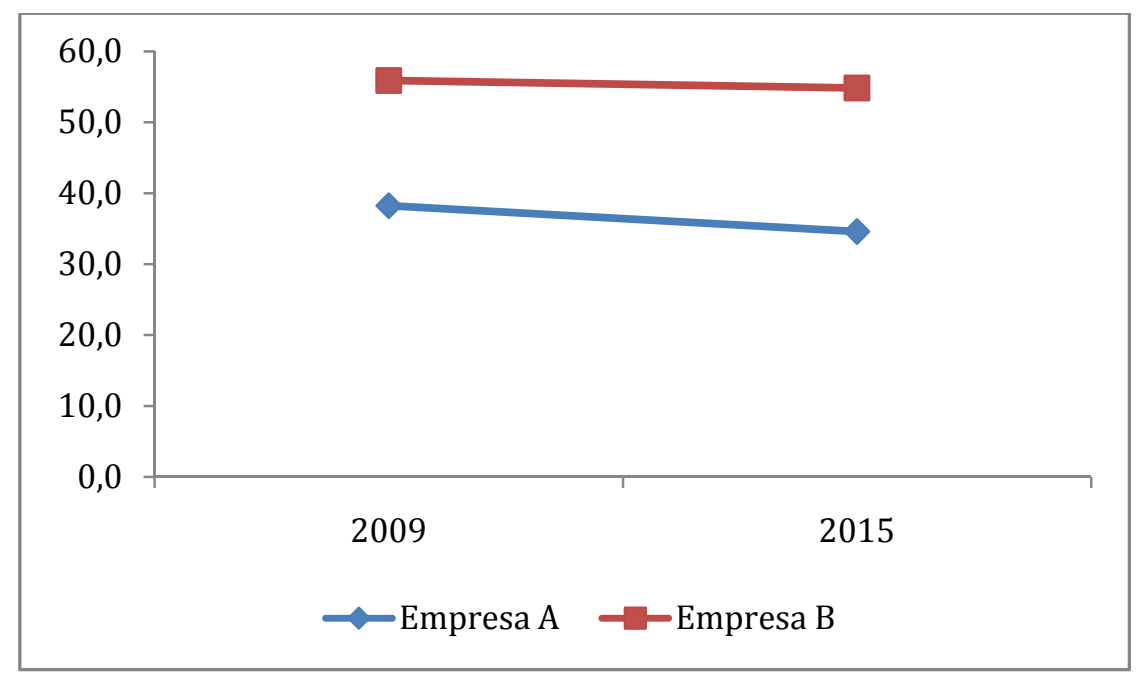

Figura 17 - Gráfico de comparação da pontuação dos estilos de liderança em 2009 e 2015/16 nas empresas $\mathrm{A}$ e $\mathrm{B}$

Fonte: Elaboração própria

Assim, em 2016 é possível constatar que o líder da empresa B pela sua pontuação manteve seu e transformacional, assim como líder da empresa $A$ em seu estilo transacional, de forma mais acentuada mas sem grandes mudanças.

\subsection{2.}

\section{Desempenho organizacional}

O desempenho das empresas foi abordado na segunda parte do questionário. A investigação sobre o desempenho foi feita a partir das análises dos líderes, e formalizadas nas respostas do questionário.

Como já foi dito anteriormente, a parte do desempenho foi analisada sob três óticas: de mercado e consumidor, financeira e satisfação dos funcionários.

Esse estudo espera deixar nítida a abordagem segregada do desempenho financeiro e o desempenho não financeiro. Reforçando a importância de medir o desempenho das empresas não apenas financeiramente, mas também por meio de variáveis não financeiras, ou físicas, conforme discutido na pesquisa bibliográfica. A primeira parte à ser analisada é a parte de mercado e consumo, através da participação de mercado da empresa, da satisfação dos consumidores, qualidade dos produtos, serviços e a inovação. 


\section{Desempenho de Mercado da Empresa "A"}

No diz respeito a posição de mercado, a empresa "A" em 2009 estava bem posicionada de acordo com o resultado do questionário. Somente uma mudança foi identificada nesse indicador em 2015, diminuindo sua média anterior de 4,8 pontos para 4,6 pontos. Isso se deve a pontuação relacionada a inovação, pois comparada com as demais empresas do mercado, observou-se que empresa poderia inovar mais, por isso diminui em 1 ponto sua resposta.

Esse fator da inovação também foi visto nas perguntas de lições aprendidas, como um ponto que poderia fortalecer os resultados da empresa, principalmente no período de crise econômica em 2008.

Os serviços prestados pela empresa "A" foram considerados acima da média do mercado, ficando com o valor máximo da escala. As demais respostas não foram alteradas. Isso envolve a satisfação dos clientes, a liderança de mercado com pelo menos $25 \%$ de participação na região que atua, e as poucas queixas com relação a prazos de entrega e a boa qualidade de seus produtos.

Assim fica registrado pelo líder, que o desempenho da empresa " $A$ " no mercado consumidor e nos temas que envolvem clientes continua satisfatório.

\section{Desempenho de Mercado da Empresa "B"}

A posição de mercado da empresa "B" em 2009 também estava bem posicionada de acordo com o resultado do questionário. Duas mudanças foram identificadas nesse indicador em 2015.

Os serviços prestados pela empresa "A" foram considerados acima da média do mercado e aumentaram de 4 para 5 pontos, ficando com o valor máximo da escala. Também evolui a satisfação dos clientes, passando de 3 para 4 pontos, sendo dito que esse cliente está disposto a pagar um pouco mais pelos produtos da empresa " $A$ ".

As demais respostas não foram alteradas, sendo reforçado que a empresa " $A$ " inova mais do a maioria de seus concorrentes, e que continua líder de seu mercado, com pelo menos $25 \%$ de participação na região que atua e que existem poucas queixas com relação a prazos de entrega e que seus produtos são de boa qualidade.

Assim fica registrado pelo líder que o desempenho da empresa "B" no mercado consumidor e no temas que envolvem clientes a empresa está bem posicionada. 


\section{Desempenho Financeiro da Empresa " $A$ "}

Assim como feito em 2009, vale ressaltar alguns pontos examinados por meio das respostas dos líderes. Primeiramente, foram avaliadas somente cinco questões referentes ao desempenho financeiro de cada uma das empresas, seguindo a metodologia adotada nesse estudo.

Em sequência as considerações do líder da empresa "A", para essas questões, são as seguintes: as contas da empresa são pagas em dia e a empresa possui boa saúde financeira. Essa afirmativa não foi alterada em 2015.

Sobre crescimento de vendas nos últimos três anos, houve um declínio. Segundo o próprio, se não fosse a crise econômica de 2008, a empresa continuaria em trajetória crescente até os dias de hoje, seguindo o crescimento da demanda por seus produtos.

Sobre ativos e estoque terem crescido no período entre 2009 e 2015 o líder concorda, mas não houve alteração de pontuação, pois a resposta em 2009 já estava em seu valor máximo de 5 pontos.

O líder em 2009 acreditava que os salários de sua empresa já estavam em níveis satisfatórios para seus subordinados. Já em 2015 diminui ( 1 ponto) sobre a afirmação de que empresa aumentou os salários em relação a média do mercado. A política salarial de sua empresa, ainda praticamente inexistente, tem ocorre pela competência e pelas tarefas atribuídas aos funcionários, e não por antiguidade.

Sobre o tema delegação de poder na empresa, o líder entende que houve uma evolução desde 2009 e em 2015 aumentou (em 1 ponto) o valor dessa afirmação. Segundo o próprio, sua empresa está departamentalizada existindo uma divisão nítida de tarefas. Embora algumas pessoas acumulem funções, as tarefas são bem divididas entre os departamentos.

Ao final, a média desse indicador passou de 4,20 pontos em 2009 para 4,00 pontos em 2015, pelas afirmações da diminuição no crescimento em vendas e em função dos salários não terem aumentado em relação a média do mercado.

\section{Desempenho Financeiro da Empresa "B"}

Utilizando as mesmas afirmativas feitas para o líder da empresa "B" em 2009, foram obtidas as considerações as seguir. Esse líder entende que as contas são pagas em dia e existe boa saúde financeira em sua empresa. Essa pergunta teve sua pontuação aumentada (1 ponto) em 2015. 
Sobre as vendas cresceram nos últimos três anos, foi uma afirmativa que diminuiu 1 ponto em 2015. Diferentemente da empresa "A", a empresa "B" não teve muito impacto com a crise econômica de 2008, mas o líder afirma que em 2015 as vendas cresceriam 10\% e estão estagnadas por conta da crise, e também citou que o movimento do comércio de rua é menor com a escassez de pessoas nas ruas da região. Não há medidas formalizadas contra a crise.

O dono da empresa "B" manteve a resposta sobre os ativos crescerem no mesmo período. Desde o início da empresa os ativos estão em crescimento. Durante esse período a empresa que tinha apenas uma filial, possui agora 3 filiais menos de 1 quilômetro da matriz e com isso houve um crescimento na sua capacidade de armazenamento.

Com relação aos salários dos funcionários, esse líder entende que continua havendo um crescimento lento. E não só concorda com o que foi respondido em 2009 , de que há um leve crescimento dos salários em relação à média do mercado, mas como também aumentou a pontuação dessa resposta em 1 ponto. O objetivo do dono é formar uma equipe de trabalho mais qualificada, portanto ele, na medida do possível, contínua reajustando os salários acima da média do mercado para que seus funcionários não migrem para o concorrente.

A última afirmativa, também teve um acréscimo de 1 ponto quando comparada com a resposta de 2015. O líder concorda que houve um crescimento de delegação com os cargo criados ao longo dos anos, desde a criação da empresa até 2009, mas o aumento da estrutura que ocorreu posteriormente a essa data.

Ao final a média desse indicador passou de 4,20 pontos em 2009 para 4,00 pontos em 2015, pelas afirmações da diminuição no crescimento em vendas e porque os salários não aumentaram em relação a média do mercado.

A seguir tabela, com algumas informações adicionais sobre a evolução financeira dos últimos cinco anos das empresas. Trata-se do valores de crescimento em vendas, lucratividade e crescimento de ativo. 
Tabela 26: Informações Financeiras Adicionais das empresas A e B

\begin{tabular}{|c|c|}
\hline \multicolumn{2}{|c|}{ Informações Financeiras Adicionais } \\
\hline $\begin{array}{l}\text { Empresa A : Comercio Atacadista de materiais } \\
\text { compostos de alta tecnologia }\end{array}$ & Observações \\
\hline $\begin{array}{l}\text { Crescimento de Vendas: } 2009 \text { a 2014: } 77 \% \text {. } \\
\text { Acumulado. Média 16\% }\end{array}$ & \\
\hline $\begin{array}{l}\text { Lucratividade: } 15,46 \% \text { média dos últimos } 5 \\
\text { anos }\end{array}$ & $\begin{array}{l}\text { Lucratividade }=(\text { Lucro liquido } / \\
\text { Receita Liquida }) \times 100 .\end{array}$ \\
\hline $\begin{array}{l}\text { Crescimento do Ativo: } 50,34 \% \text { crescimento ao } \\
\text { longo de } 5 \text { anos. }\end{array}$ & $\begin{array}{l}\text { Crescimento do Ativo }=\text { ativo do } \\
\text { estoque }+ \text { contas a receber }\end{array}$ \\
\hline $\begin{array}{l}\text { Empresa B: Comercio Atacadista de } \\
\text { embalagens }\end{array}$ & \\
\hline $\begin{array}{l}\text { Crescimento de Vendas: 114,2\%. Acumulado. } \\
\text { Média } 19 \%\end{array}$ & $\begin{array}{l}\text { (distorção no número - em } 2011 \\
\text { abriu uma loja e o crescimento foi de } \\
40 \% \text {. se considerar o crescimento } \\
\text { sem a expansão do negócio a média } \\
\text { cai pra } 14,5 \% \text { ) }\end{array}$ \\
\hline Lucratividade: $12 \%$ Média dos 5 último anos. & $\begin{array}{l}\text { Lucratividade }=(\text { Lucro liquido } / \\
\text { Receita Liquida }) \times 100 .\end{array}$ \\
\hline $\begin{array}{l}\text { Crescimento do Ativo: } 37,16 \% \text { crescimento ao } \\
\text { longo de } 5 \text { anos. }\end{array}$ & $\begin{array}{l}\text { Crescimento do Ativo }=\text { ativo do } \\
\text { estoque }+ \text { contas a receber }\end{array}$ \\
\hline
\end{tabular}

Fonte: Elaboração própria

\section{Percepção de Clima Organizacional na Empresa " $A$ "}

O último item da seção do desempenho envolve o tema satisfação dos funcionários. Foi aplicado o mesmo questionado utilizado em 2009 sobre como os funcionários compreendem o clima e o ambiente de trabalho. Na empresa $\mathrm{A}$, a satisfação dos funcionários não foi alterada, a média das respostas em 2009 era 2,80 pontos e foi mantida em 2015.

$\mathrm{Na}$ primeira afirmativa diz respeito ao funcionários reconhecerem para seus amigos que ele trabalha em uma boa organização. Essa afirmativa subiu 1 ponto em 2015, quanto comparada a 2009.

Quanto a ter uma boa relação com o chefe, essa foi diminuída em 1 ponto em 2015, ficando no valor mínimo da escala.

Sobre se os valores da empresa são convergentes com seus valores pessoais, essa afirmação não teve mudança ficando com a pontuação 4 .

A afirmativa sobre comprometimento diário com o trabalho teve a resposta diminuída em 1 ponto em 2015, ficando no valor mínimo da escala. Reforçando o ponto já apresentado em 2009 de falta de motivação da equipe. 
Comparada a resposta de 2009, sobre a afirmativa dos funcionários estarem sendo remunerados de forma justa e compatível ao seu nível de instrução, experiência profissional e trabalho desempenhado, em 2015 essa resposta subiu 1 ponto. Uma suposição para esse resultado, é a ocorrência de novos entrantes na empresa.

Fundamentada nessas respostas é possível compreender que a liderança transacional do sócio da empresa "A" como sendo pouco ou não satisfatória para os funcionários.

\section{Percepção de Clima Organizacional na Empresa "B"}

A empresa "B" nas questões relativas ao clima organizacional ou satisfação no ambiente de trabalho nas respostas de 2009 , apresentou duas respostas com mesmo valores e três com valores superiores em 2015.

Sobre trabalhar numa empresa boa, essa resposta foi aumentada em 1 ponto, ficando com 4 pontos na escala de 5 pontos. Isso demonstra, assim como em 2009, que os funcionários estão satisfeitos em trabalhar nessa empresa e tem orgulho em comunicar isso.

No que diz respeito a relação entre o funcionário e o líder, a resposta também aumentou a pontuação ficando em 5 pontos, o valor máximo da escala.

A afirmativa sobre os valores da empresa " $B$ " serem reconhecidos como parecidos com os valores explicitados pelos funcionários, também aumentou em 1 ponto em 2015.

Em 2009, foi citado no estudo que apesar de um desempenho satisfatório no ambiente de trabalho, os funcionários não foram convincentes sobre seu comprometimento em sua respectiva rotina. E mesmo comunicando sentir orgulho em trabalhar na empresa "B", a pesquisa aponta naquele momento que apenas $50 \%$ dos respondentes afirmaram estar comprometidos com o trabalho, sendo essa nota mantida na resposta ao questionário de 2015.

Por fim, a satisfação com salários baseados no nível de instrução, experiência profissional e trabalho desempenhado pelos funcionários, foi uma das três respostas que tiveram seu valor aumentado em 1 ponto na resposta de 2015.

A média desse passou de 3,4 pontos em 2009, para 4,0 pontos em 2015. Com esse resultado pode-se inferir que os funcionários estão satisfeitos com o ambiente de trabalho. 


\section{Quadros analíticos sobre desempenho}

A seguir as tabelas e gráficos com as médias finais dos indicadores de desempenho das empresas $A$ e $B$, considerando a escala de 1 a 5 para as respostas, em que um foi apontado para a pessoa que discorda completamente e cinco para aquela que concordava completamente:

Tabela 27: Médias finais dos indicadores de desempenho - Empresa A

\begin{tabular}{|c|c|c|}
\hline & 2009 & 2015 \\
\hline Desempenho de Mercado e Consumidor & 4,80 & 4,60 \\
\hline Desempenho Financeiro & 4,20 & 4,00 \\
\hline Desempenho de Clima Organizacional & 2,8 & 2,8 \\
\hline Desempenho Total & 3,93 & 3,80 \\
\hline
\end{tabular}

Fonte: Elaboração própria

Tabela 28: Médias finais dos indicadores de desempenho - Empresa B

\begin{tabular}{|l|r|r|}
\cline { 2 - 3 } \multicolumn{1}{c|}{} & \multicolumn{1}{c|}{$\mathbf{2 0 0 9}$} & \multicolumn{1}{c|}{2015} \\
\hline Desempenho de Mercado e Consumidor & 4,00 & 4,40 \\
\hline Desempenho Financeiro & 3,60 & 4,00 \\
\hline Desempenho de Clima Organizacional & 3,40 & 4,00 \\
\hline Desempenho Total & $\mathbf{3 , 6 7}$ & $\mathbf{4 , 1 3}$ \\
\hline
\end{tabular}

Fonte: Elaboração própria

As tabelas acima sobre o desempenho demonstram que as duas empresas tiveram julgamentos divergentes. Os indicadores da empresa $A$ apresentam resultados que, na média, se mantiveram ou declinaram, enquanto a empresa $B$ teve em suas médias um aumento dos resultados de todos os seus indicadores. Além disso, vale destacar que comparativamente com 2009, os funcionários da empresa "A" continuam em 2015 com baixa satisfação no diz respeito ao ambiente e o clima organizacional, contrapartida os funcionários da empresa "B" estão mais satisfeitos.

A seguir tabela com o resumo de todas as médias finais dos tópicos agrupados das empresas A e B. 
Tabela 29: Evolução dos indicadores de desempenho entre 2009 e 2015 - Empresas A e B

\begin{tabular}{|c|c|c|c|c|c|c|}
\hline & \multicolumn{2}{|c|}{ Empresa A } & \multirow{2}{*}{$\begin{array}{l}\text { Variação } \\
\text { do } \\
\text { Indicado } \\
\text { r }\end{array}$} & \multicolumn{2}{|c|}{ Empresa B } & \multirow{2}{*}{$\begin{array}{c}\text { Variação } \\
\text { do } \\
\text { Indicador }\end{array}$} \\
\hline & 2009 & 2015 & & 2009 & 2015 & \\
\hline $\begin{array}{l}\text { Desempenho } \\
\text { de Mercado e } \\
\text { Consumidor }\end{array}$ & 4,80 & 4,60 & $\downarrow$ & 4,00 & 4,40 & T \\
\hline $\begin{array}{c}\text { Desempenho } \\
\text { Financeiro }\end{array}$ & 4,20 & 4,00 & $\downarrow$ & 3,60 & 4,00 & $\uparrow$ \\
\hline $\begin{array}{l}\text { Desempenho } \\
\text { de Clima } \\
\text { Organizacional }\end{array}$ & 2,80 & 2,80 & $=$ & 3,40 & 4,00 & 个 \\
\hline $\begin{array}{c}\text { Desempenho } \\
\text { Total }\end{array}$ & 3,93 & 3,80 & $\downarrow$ & 3,67 & 4,13 & $\mathbf{T}$ \\
\hline
\end{tabular}

Fonte: Elaboração própria

De forma geral é possível dizer que o líder da empresa "A" foi em 2009 considerado líder transacional e o líder da empresa "B" que ficou acima dos três pontos, foi considerado líder transformacional. Em 2015/16 isso permanece, pois essas características tiveram poucas alterações em relação aos resultados da pesquisa.

Em 2009 o desempenho geral das duas empresas demonstrou níveis satisfatórios, sendo que a empresa "B" teve um melhor desempenho.

Já em 2015/16 os indicadores demonstram uma distância maior entre as empresas, posicionando a empresa A com seus indicadores em declínio ou estáveis,e no desempenho geral com resultado menor comparado a 2009.

A empresa "B" continua com crescimento em todos seus indicadores de desempenho com um índice geral bem satisfatório para todos os índices de desempenho apresentados e uma média desempenho geral acima de quatro pontos. 


\section{Conclusão}

Esse estudo teve como objetivo analisar a influência do estilo de liderança no desempenho na fase de amadurecimento do ciclo de vida de uma organização, considerando as teorias de três campos de estudo: (a) os ciclos de vida organizacional, (b) as características liderança que os tomadores de decisão possuem e expressam, e (c) indicadores de desempenho.

Para atingir os objetivos pretendidos, foi realizado um estudo longitudinal combinando uma abordagem qualitativa e quantitativa para analisar duas pequenas empresas familiares cariocas do comércio varejista. Os casos selecionados focaram em empresas na fase de amadurecimento segundo o modelo de Greiner (1998) em que foram aplicados questionários elaborados a partir dos pilares de liderança situacional de Bass (1990) e com base nas questões de Pillai et al. (1999).

Foi realizada em 2015/16 uma nova aplicação do questionário sobre estilo de liderança e indicadores de desempenho, nas duas empresas que participam do primeiro do estudo de Riche, L. (2009), envolvendo a equipe influenciada diretamente por esses líderes.

A partir dos resultados apresentados na consolidação e análise dos questionários aplicados em 2015/16, é possível verificar que o estilo de liderança dos lideres das empresas pesquisadas não sofreu alterações significativas quando comparados aos resultados de 2009, mantendo o líder "A" com o estilo transacional, e líder "B" com o transformacional.

Posicionados no Grid Gerencial de Blake e Mouton (1995), o líder da empresa "A" se aproxima da gerência de autoridade/obediência com maior interesse pela produtividade do que o interesse pelas pessoas. A empresa "B", o perfil do homem organizacional e o estímulo do trabalho em equipe tem como resposta um equilíbrio entre interesse pelas pessoas e pela produtividade, com ênfase no trabalho em equipe que incentiva as relações de confiança e respeito dos liderados em direção a alta produtividade. 
O líder da empresa "A" apresenta suas idéias a equipe e limita a influência no processo decisório. Essa afirmativa satisfaz a terceira posição numa escala de sete pontos do modelo de liderança situacional de Tannenbaum e Schmidt (1986).

Já o estilo de liderança do líder "B" estaria mais próximo das escalas cinco e seis, representando um líder que apresenta o problema, recebe sugestões e toma decisão junto com a equipe por consenso, por isso, seu estilo estaria mais próximo de uma liderança democrática do que autoritária para esses autores.

Observou-se uma relação positiva entre estilo de liderança do tomador de decisão e o desempenho. A liderança transformacional da empresa "B" em média gerou melhores resultados do que na empresa "A" com uma liderança transacional, reforçando o resultado do estudo de 2009. Além de sugerir que um estilo de liderança transformacional, que se sobrepõe a um estilo liderança transacional apresenta ser no estágio de amadurecimento das empresas um diferencial para o resultados alcançados.

Em 2015/16 as empresas estão praticamente vivendo o mesmo estágio do ciclo de vida, a fase de amadurecimento ou regulamentação, pois em 2009 as duas empresas estavam em estágios diferentes do ciclo de vida de acordo com a metodologia de Greiner (1989). A empresa "A" estaria na fase de regulamentação, vivenciado a crise de controle e falta de profissionalismo nos processos observados pela empresa. A empresa "B", por sua vez, na fase de expansão, pois os departamentos não estavam completamente formalizados e o líder concentrava várias decisões operacionais e estratégicas.

Entretanto, em 2015/16 as duas empresas possuem em geral características que as posicionam na mesma fase, sendo possível supor que nesse caso estarem em diferentes fases do ciclo de vida não favoreceu por exemplo o desempenho futuro da empresa $A$, que já vivenciava um estágio a frente da empresa B, como indicado na conclusão do estudo de 2009.

Os resultado de 2015/16, apresenta um contínuo crescimento dos indicadores da empresa $\mathrm{B}$ e um decréscimo ou estagnação dos indicadores da empresa A. Distanciando os resultados apresentados pelas duas empresas em 2009.

Esse fato pode sugerir uma correlação entre o estilo de liderança do líder da empresa e seus respectivos resultados. Como, por exemplo o indicador de clima organizacional, que em 2015/16, assim como em 2009, apresenta um resultado inferior na empresa " $A$ " com um líder transformacional ao da empresa "B" com uma liderança transformacional. 
Sendo possível indicar um paralelo entre a liderança transacional e um menor desempenho de clima organizacional, ao mesmo tempo em que, nesse caso também podemos correlacionar a liderança transformacional a melhores desempenhos de clima organizacional.

Também é plausível inferir que a lacuna deixada pela falta de um sistema de gestão integrado, que pudesse fortalecer os processos e as diretrizes na empresa "A" pode ser um dos motivos significativos de descontentamento com retrabalhos e falhas humanas que impacta o baixo desempenho de clima organizacional nessa empresa. A implantação do sistema informatizado planejado para ser instalado em 2016, deverá minimizar esse ponto. Os processos na empresa "B" são mais integrados e parcialmente informatizado, o que pode ser um motivo a menos de desgaste durante o trabalho.

No entanto, não é possível dizer que a falta desse sistema integrado de informações gerencias foi uma limitação direta ao crescimento financeiro e de mercado para a empresa " $A$ ", como também não pode-se concluir que esse tipo de sistema aumentará seu crescimento. Entretanto, de acordo seu escopo, poderá suportar melhor o crescimento da empresa, no que diz respeito a maior confiabilidade desses processos automatizados.

Essas variáveis mostram que os fatores envolvidos no negócio da vida real são complexos, em um estado constante de movimento, e mudam rapidamente ao longo do tempo. Sendo as variáveis selecionadas nesse estudo foram examinadas de forma restritiva e isoladas dos efeitos mais abrangentes do ambiente de negócios no qual elas funcionam.

A consideração final é sobre o impacto que um líder empresarial tem sobre a organização. Esse impacto do líder depende da sua interação com vários fatores (ou seja, a fase do ciclo de vida, os fatores ambientais e os fatores de negócios), e não somente de suas habilidades. Pode ser dito que os líderes se comportam de uma forma que lhes permite preencher uma necessidade organizacional particular.

Verdadeiros líderes compartilham a capacidade de unificar, esclarecer e orientar. Os líderes podem mudar a normas, crenças e direção de uma organização de maneiras sutis e ostensivas, às vezes mudando paradigmas indústria inteira (SCHEIN, 2004). 
Os líderes são descritos e definidos por suas características e comportamentos. É por meio destas características que um líder processa a circunstância e meio ambiente, formula decisões, e comunica visão e direção para os outros. Portanto, em função de seu impacto, entender as características de um líder, é de grande valor, assim como compreender o impacto do papel destes estilos no desempenho,para a determinação dos próximos passos do negócio.

\section{1.}

\section{Sugestões e recomendações para novas pesquisas}

Como desdobramentos futuros, essa linha de pesquisa pode ser estendida por meio de uma investigação mais ampla de outros fatores de liderança e de negócios. Uma vez que, especificamente, o foco desta pesquisa foi para compreender o efeito que um fator negócio tem sobre outro no contexto do desempenho organizacional.

Em segundo lugar, os indicadores de desempenho utilizados (resultados financeiros, mercado e consumidor, satisfação de funcionários), são algumas das várias influências internas e externas que pressionam uma organização.

Pesquisas futuras podem também considerar um maior números de casos, para entender se resultados serão alterados. Incorporando as organizações de tamanhos variados, de diferentes status financeiro (ou seja, receitas, margem bruta, fluxo de caixa, o lucro), permitiria ao pesquisador observar se as relação de liderança, fase do ciclo de vida e os indicadores são semelhantes por meio de tais variáveis ou se são exclusivamente ligada a um ou mais desses fatores organizacionais.

O produto ou serviço prestado e o setor da indústria desempenham um papel importante na definição de como uma organização opera. As duas organizações neste estudo fazem parte de comércio. Adição de representantes de outros setores da indústria e organizações que prestam serviços, ao contrário dos produtos, poderiam produzir algumas distinções liderança interessantes. 


\section{6 Referências bibliográficas}

ADIZES, I. Os ciclos de vida das organizações: como e porque as empresas crescem e morrem e o que fazer a respeito. São Paulo: Pioneira, 1998.

Organizational passages: diagnosing and treating life cycle problems in organizations. Organizational Dynamics. Filadélfia. v. 8, n. 1, p. 3-25. 1979.

ALBUQUERQUE, J. A arte de lidar com as pessoas: a inteligência interpessoal aplicada. São Paulo: Planeta, 2003.

ALVES, R. D.; SILVA, J. R. G. Empreendedorismo e o processo de identificação de oportunidades. 2005. 115 f. Dissertação (Mestrado em Administração) - Pontifícia Universidade Católica do Rio de Janeiro, Rio de Janeiro, 2005.

ANBREU, M. J. C.; SILVA, G. A. V. Contratos psicológicos nas organizações: Bases de sua construção. Revista de Gestão USP, São Paulo, v. 13, n. spe, p. 93104, 2006.

AVOLIO, B. J. Promoting more integrative strategies for leadership theorybuilding. American Psychologist, v. 62, n. 1, p. 25, 2007.

. et al.. Unlocking the mask: A look at the process by which authentic leaders impact follower attitudes and behaviors. The Leadership Quarterly, v. 15, n. 6, p. 801-823, 2003.

WALDMAN, D. A.; EINSTEIN, W. 0. Transformational leadership in a management simulation: Affecting the bottom line. Group and Organization Studies, 59-80. 1988.

BARLING, J.; WEBER, T.; KELLOWAY, E. K. Effects of transformational leadership training on attitudinal and financial outcomes: A field experiment. Journal of Applied Psychology, v. 81, n. 6, p. 827, 1996.

BARNEY, J. B. Is the resource-based "view" a useful perspective for strategic management research? Yes. Academy of Management Review, v. 26, n. 1, p. 4156, 2001.

BASS, B. M. Does the transactional-transformational leadership paradigm transcend organizational and national boundaries?. American psychologist, v. 52, n. 2, p. 130, 1997.

. Handbook of leadership. New York: Free Press. 1990.

Leadership and Performance Beyond Expectations. New York, NY: Free Press; Collier Macmillan, 1985a.

Leadership: Good, better, best. Organizational dynamics, Filadélfia. v. 13, n. 3, p. 26-40, 1985 b. 
.; AVOLIO, B. J. Developing transformational leadership: 1992 and

beyond. Journal of European industrial training, v. 14, n. 5, 1990.

.; JUNG, D. I.; AVOLIO, B. J.; \&BERSON, Y. l. Predicting unit performance by assessing transformational and transactional leadership. Journal of Applied Psychology, v. 88, n. 2, p. 207, 2003.

BAZERMAN, M.; MOORE, D. A. Judgment in managerial decision making. Danvers, MA: John Wiley \& Sons, 2012.

BENNIS, W. G.; NANUS, B. Leaders: The strategies for taking charge. New York: Harper \& Row. 1985.

BLAKE, R. R.; MOUTON, J. S. O Grid Gerencial III.São Paulo: Pioneira, 1995.

BRIGHAM, E. F.; GAPENSKI, L. C.; ENHARDT M. C. Administração Financeira: teoria e prática. Atlas, 2001.

BROCKNER, J.; JAMES, E. H. Toward an understanding of when executives see crisis as opportunity. The Journal of Applied Behavioral Science, v. 44, n. 1, p. 94-115, 2008.

BRYMAN, A. Charisma and leadership in organizations. Sage Pubns, 1992.

BURNS, J. M. Leadership New York.NY: Harper and Row Publishers, 1978.

BUSSAB, W. O.; MORRETTIN, P. A. Estatística básica. 5a. São Paulo: Saraiva, 2003.

BYCIO, P.; HACKETT, R. D.; ALLEN, J. S. Further assessments of Bass's (1985) conceptualization of transactional and transformational leadership. Journal of Applied Psychology, v. 80, p. 468-478. 1995.

CAllado, A. L. C.; CALladO, A. A. C.; AlMEIDA, M. A. A utilização de indicadores de desempenho não-financeiros em organizações agroindustriais: um estudo exploratório. Organizações Rurais \& Agroindustriais, v. 10, n. 1, 2011.

CAMERON, K. S.; WHETTEN, D. A. Perceptions of organizational effectiveness over organizational life cycles. Administrative Science Quarterly, p. 525-544, 1981.

CARNEIRO, J. M. T.; SILVA, J. F.; ROCHA, A.; DIB, L. A. R. Building a bettermeasureof business performance. RAC-Eletrônica, v. 1, n. 2, p. 114-135, Maio/Ago. 2007.

CARVER, C. S. Resilience and thriving: Issues, models, and linkages. Journal of Social Issues, v. 54, n. 2, p. 245-266, 1998.

CAVALCANTI, V. L. et al. Liderança e Motivação. 2a ed. Rio de Janeiro: FGV, 2006. 
CHIAVENATO, I. Gestão de Pessoas: o novo papel dos recursos nas organizações. $2^{\mathrm{a}}$ edição. Rio de Janeiro: Elsevier, 2004.

CONGER, J. A. The charismatic leader: Behind the mystique of exceptional leadership. Jossey-Bass, 1989.

.; KANUNGO, R. N. Behavioral dimensions of charismatic leadership. In: CONGER, J. A.; KANUNGO, R. N. (Eds.), Charismatic leadership: The elusive factor in organizational effectiveness. San Francisco: Jossey-Bass. p. 78- 97. 1988.

CRESWELL, J. W. Projeto de pesquisa: métodos qualitativo, quantitativo e misto. Porto Alegre: Artmed; 2010.

DAY, D. V.; LORD, R. G. Executive leadership and organizational performance: Suggestions for a new theory and methodology. Journal of Management, v. 14, n. 3, p. 453-464, 1988.

DAY, G. S.; SCHOEMAKER, P. J. H. Are You a'Vigilant Leader'?. MIT Sloan Management Review, v. 49, n. 3, p. 43, 2008.

DENISON, D. R.; MISHRA, A. K. Toward a theory of organizational culture and effectiveness. Organization Science, v. 6, n. 2, p. 204-223, 1995.

DESS, Gregory G.; ROBINSON, Richard B. Measuring organizational performance in the absence of objective measures: the case of the privately held firm and conglomerate business unit. Strategic Management Journal, v. 5, n. 3, p. 265-273, 1984.

DODGE, H. R.; FULLERTON, S.; ROBBINS, J. E. Stage of the organizational life cycle and competition as mediators of problem perception for small businesses. Strategic Management Journal, v. 15, n. 2, p. 121-134, 1994.

DOWNS, A. The life cycle of bureaus. Inside Bureaucracy, San Francisco, CA, p. 296-309, 1967.

DUSILEK, D. A arte da investigação criadora: introdução à metodologia da pesquisa. JUERP, 1982.

FEY, C. F.; DENISON, D. R. Organizational culture and effectiveness: can American theory be applied in Russia?. Organization Science, v. 14, n. 6, p. 686706, 2003.

FREZATTI, F.; RELVAS, T. R. S.; JUNQUEIRA, E. R.; NASCIMENTO, A. R. Análise do perfil de planejamento associado ao ciclo de vida organizacional nas empresas brasileiras. In: CONGRESSO USP FIPECAFI. São Paulo. v. 9. p. 115. 2009.

GALBRAITH, J. Designing the innovating organization. Organizational Dynamics, v. 10, n. 3, p. 5-25, 1982 b. 1982a. The stages of growth. Journal of Business Strategy, v. 3, n. 1, p. 70-79, 
GARDNER, W. L. et al. "Can you see the real me?" A self-based model of authentic leader and follower development. The Leadership Quarterly, v. 16, n. 3, p. 343-372, 2005.

GORDON, G. G. The relationship of corporate culture to industry sector and corporate performance. Gaining control of the corporate culture, v. 103, p. 125, 1985.

GREINER, L. E. Evolution and revolution as organizations grow-Larry E. Greiner responds. Harvard Business Review, v. 76, n. 4, p. 178-179, 1998.

HAIRE, M. Biological models and empirical histories of the growth of organizations. Modern organization theory, New York: Wiley \& Sons. p. 272306, 1959.

HANSEN, G. S.; WERNERFELT, B. Determinants of firm performance: The relative importance of economic and organizational factors. Strategic Management Journal, v. 10, n. 5, p. 399-411, 1989.

HERSEY, P.; BLANCHARD, K. H. Psicologia para administradores: a teoria e as técnicas da liderança situacional. In: Psicologia para administradores: a teoria e as técnicas da liderança situacional. Epu, 1986.

HOUSE, R. J.; MITCHELL, T. R. Path-goal theory of leadership. Journal of Contemporary Business, v. 3, n. 4, p. 81-98, 1974.

HUNT, J. G. Transformational/charismatic leadership's tranformation of the field: An historical essay. The Leadership Quarterly, v. 10, n. 2, p. 129-144, 1999.

JAMES, E. H.; WOOTEN, L. P. Leadership as (Un)usual: How to Display Competence in Times of Crisis. Organizational Dynamics, v. 34, n. 2, p. 141152, 2005.

JAWAHAR, I. M.; MCLAUGHLIN, G. L. Toward a descriptive stakeholder theory: An organizational life cycle approach. Academy of Management Review, v. 26, n. 3, p. 397-414, 2001.

KANJI, G.; MOURA E SÁ, P. Performance Measurement and Business Excellence: The Reinforcing Link for the Public Sector. Total Quality Management and Business Excellence, v. 18, n. 1-2, p. 49-56, 2007.

KAPLAN, R.; NORTON, D. The balanced scorecard. Harvard Business Review, v. 84, n. 3, p. 100-109, 2005.

KERNIS, M. H. Toward a conceptualization of optimal self-esteem. Psychological Inquiry, v. 14, n. 1, p. 1-26, 2003.

KELLEY, R. E. The power of followership. New York: Currency and Doubleday. KELLER, R. T. 1992. Transformational leadership and the performance of research and development project groups. Journal of Management, v. 18, p. 489501. 1992. 
KIMBERLY, J. R.; MILES. R. H. The Organizational Life Cycle. San Francisco: Iossey-Bass, p. 81. 1980.

KIRKPATRICK, S. A.; LOCKE, E. A. Direct and indirect effects of three core charismatic leadership components on performance and attitudes. Journal of Applied Psychology, v. 81, n. 1, p. 36, 1996.

KOTTER, J. P. What leaders really do. Harvard Business Review, v. 68, n. 3, p. 103-111. 2009.

KWON, D.; OH, W.; JEON, S. Broken ties: the impact of organizational restructuring on the stability of information-processing networks. Journal of Management Information Systems, v. 24, n. 1, p. 201-231, 2007.

LEHMANN, E. L.; D'ABRERA, H. J. M. Non parametrics: statistical methods based on ranks. New York: Springer, 2006.

LESTER, D. L.; PARNELL, J. A.; CARRAHER, S. Organizational life cycle: A five-stage empirical scale. The International Journal of Organizational Analysis, v. 11, n. 4, p. 339-354, 2003.

LIEBERSON, S.; O'CONNOR, J. F. Leadership and organizational performance: A study of large corporations. American Sociological Review, v. 37, p. 117-130, 1972.

LIPPITT, G. L.; SCHMIDT, W. H. Crises in a developing organization. Harvard Business Review, v. 45, p. 102-112, 1967.

LOWE, K. B.; KROECK, K. G.; SIVASUBRAMANIAM, N. Effectiveness correlates of transformational and transactional leadership: A meta-analytic review of the MLQ literature. The Leadership Quarterly, v. 7, n. 3, p. 385-425, 1996.

LYDEN, F. J. Using Parsons' functional analysis in the study of public organizations. Administrative Science Quarterly, v. 20, p. 59-70, 1975.

LUTHANS, F.; AVOLIO, B. Authentic leadership: a positive development approach. Positive Organizational Scholarship. San Francisco, CA: BerrettKoehler. p. 241-258, 2003.

MACEDO, M. A. S.; SILVA, F. F. Análise de desempenho organizacional: utilizando indicadores financeiros e não financeiros na avaliação de performance empresarial. Anais do Encontro da Associação Nacional dos Programas de PósGraduação em Administração - Anpad XXVIII. Curitiba. v. 28, 2004.

MALLAK, L. Putting organizational resilience to work. Industrial Management. v. 40, n. 6, p. 8-13, 1998.

MARCOULIDES, G. A.; HECK, R. H. Organizational culture and performance: Proposing and testing a model. Organization Science, v. 4, n. 2, p. 209-225, 1993. 
MARION, R.; UHL-BIEN, M. Leadership in complex organizations. The Leadership Quarterly, v. 12, n. 4, p. 389-418, 2002.

MEKRAZ, A. Impacting retail store performance: A correlational study of the relationship between transformational and transactional leadership style and bottom line performance indicators. 2011. 151f. Tese de Doutorado. CAPELLA UNIVERSITY, Minneapolis, 2011. Disponível em: <http://139.82.115.33/docview/894417450?accountid=26649>. Acesso em: 15 maio de 2015.

MINTZBERG, H. Strategy-making in three modes. Califórnia Management Review (pre-1986), v. 16, n. 2, p. 44, 1973.

.; WESTLEY, F. Cycles of organizational change. Strategic Management Journal (1986-1998), v. 13, n. SPECIAL ISSUE, p. 39, 1992.

MILLER, D.; FRIESEN, P. H. A longitudinal study of the corporate life cycle. Management Science, v. 30, n. 10, p. 1161-1183, 1984.

NATAL, A. C., Medição de Desempenho Logístico: Práticas das grandes empresas no Brasil. 2005. Dissertação de mestrado em Administração, COPPEAD-UFRJ, Rio de Janeiro, 2005.

NEELY, Andy. The performance measurement revolution: why now and what next?. International journal of operations \& production management, v. 19, n. 2, p. 205-228, 1999.

O'RAND, A. M.; KRECKER, M. L. Concepts of the life cycle: Their history, meanings, and uses in the social sciences. Annual Review of Sociology, p. 241262, 1990.

REJAS, L. P.; PONCE, E. R. Estilos de liderazgo y eficacia: um estúdio em pequeñas empresas en Chile. Interciencia: Revista de ciencia y tecnología de América, v. 31, n. 7, p. 500-504, 2006.

PEDRO, A. M.; ÁlvARO, G. R. L. Características Comportamentais dos Empreendedores no Modelo de Ciclo de Vida das Organizações de Greiner. 2003. 113f. Dissertação (Mestrado em Engenharia de Produção) - Programa de Pós-Graduação em Engenharia de Produção, UFSC, Florianópolis,2003.

PFEFFER, J.; SALANCIK, G. R. Determinants of supervisory behavior: A role set analysis. Human Relations, v. 28, n. 2, p. 139-154, 1975.

PILLAI, R.; SCHRIESHEIM, C. A.; WILLIAMS, E. S. Fairness perceptions and trust as mediators for transformational and transactional leadership: A two-sample study. Journal of Management, v. 25, n. 6, p. 897-933, 1999.

QUINN, R. E.; CAMERON, K. Organizational life cycles and shifting criteria of effectiveness: Some preliminary evidence. Management Science, v. 29, n. 1, p. 33-51, 1983. 
REIDER, M. C. The role of leadership traits in driving organizational life cycle decisions. 2011. 138p. These. Doctor of Management. University of Maryland University College, Ann Arbor, 2011.

RIBEIRO, J. M. M. Medição de desempenho organizacional nas imobiliárias. Dissertação de mestrado em Ciências Contábeis, Universidade Federal do Rio Grande do Norte, Natal - RN. 2004.

RICHE, L. A influência dos estilos de liderança no desempenho da pequena empresa familiar: Um estudo de caso. 104f. Dissertação (Mestrado em Administração), Pontifícia Universidade Católica do Rio de Janeiro, Rio de Janeiro, 2009.

ROUECHE, J. E.; BAKER III, G. A.; ROSE, R. R. Shared vision: Transformational leadership in American community colleges. Rowman \& Littlefield, 2014.

SASHKIN, M. The visionary leader. In: CONGER, J. A.; KANUNGO, R. N. (Eds.), Charismatic leadership: San Francisco: Jossey-Bass. p. 122-160. 1988.

SCHEIN, E. H. Organizational culture and leadership. San Francisco, CA: Jossey-Bass. 2004.

SCHREIBER, C.; CARLEY, K. M. Leadership style as an enabler of organizational complex functioning. Emergence: Complexity \& Organization, v. 8, n. 4, p. 61-76, 2006.

SCOTT, B. R. Stages of Corporate Development. Boston, MA: Harvard Business School, Intercollegiate Case Clearing House, 123 p.1971.

SEBRAE - Serviço Brasileiro de Apoio às Micro e Pequenas Empresas - Site Disponível em: <http://www.sebrae.com.br>. Acesso em: Janeiro de 2014.

SMITH, K. G.; MITCHELL, T. R.; SUMMER, C. E. Top level management priorities in different stages of the organizational life cycle. Academy of Management Journal, v. 28, n. 4, p. 799-820, 1985.

STEINMETZ, L. L. Critical stages of small business growth: when they occur and how to survive them. Business Horizons, v. 12, n. 1, p. 29-36, 1969.

STOGDILL, R. M. Handbook of Leadership: A survey of the literature. New York, NY: Free Press.1974.

SOUSA, M. F. N. A Liderança Autêntica e a Criatividade dos Colaboradores. 2009. 186f. Tese Doutorado em Gestão. Universidade de Trás-os-Montes e Alto Douro. Departamento de Economia, Sociologia e Gestão, 2009.

SULL, D. N.; ESCOBARI, M. E. Sucesso Made in Brasil: os segredos das empresas brasileiras que dão certo. Rio de Janeiro: Elsevier, $8^{\circ}$ edição. 2004.

TANNENBAUM, A. S.; SCHMITT, W. H. How to choose a leadership pattern. Harvard Business Review, v. 36, p. 95-101, 1958. 
TANURE, B.; NETO, A. C.; ANDRADE, J. Executivos - Sucesso e (in)Felicidade. Rio de Janeiro: Elsevier, 2007.

THOMAS, A. B. "Does leadership make a difference to organizational performance?." Administrative Science Quarterly. p. 388-400, 1988.

TICHY, N.; DEVANNA, M. The Transformational Leader. New York: Wiley, 1986.

TOMEI, P. A. Cultura Empreendedora - Guia prático para seleção de empreendedores. 1o ed. - Rio de Janeiro: Office Book Editora, 2008.

TORBERT, W. R. Pre-bureaucratic and post-bureaucratic stages of organization development. Interpersonal Development, v. 5, p. 1-25, 1974.

VENKATRAMAN, N.; RAMANUJAM, V. Measurement of business performance in strategy research: A comparison of approaches. Academy of Management Review, v. 11, n. 4, p. 801-814, 1986.

VERGARA, S. C. Projetos e relatórios de pesquisa em administração. 9a ed. São Paulo: Atlas, 2007.

VROOM, V. H.; YETTON, P. W. Leadership and decision-making. Pittsburg, PA: University of Pittsburg Press, 1973.

WHITE, R. K.; LIPPITT, R. Autocracy and democracy: An experimental inquiry. New York: Harper, 1960.

YUKL, G. An evaluation of conceptual weaknesses in transformational and charismatic leadership theories. The Leadership Quarterly, v. 10, n. 2, p. 285305, 1999. 


\section{Anexo 1}

\section{Empresa A - Resposta Líder}

Definindo os estilos de liderança

1 - Discordo plenamente

2 - Apenas Discordo

3 - Não Concordo nem discordo

4 - Apenas Concordo

5 - Concordo plenamente

2009 / 2015

1) Você é recompensado de acordo com o cumprimento de suas tarefas*. 5_l_4_

2) $\overline{\mathrm{O}}$ seu chefe fica atento todo dia com os processos do dia-a-dia e toma ações corretivas quando alguma coisa não sai como ele imaginou ou quando há descumprimento das normas*._5_/_3_

3) Seu líder só atua quando há descumprimento das regras*._2 I_3

4) Seu líder evita tomar decisões e se exime de responsabilidades*.

5) As atitudes do seu líder fazem com que seus seguidores o respeitem. 5_/5

6) Você sente orgulho de trabalhar para seu líder. 4_/_4_

7) Seu líder encara de forma séria as necessidades pessoais dos colaboradores._3_/_3_

8) Ele mostra respeito pelos sentimentos individuais dos seguidores. 2_l_2_

9) Passa por cima de seus interesses para o bem dos colaboradores. 3_l_4

10) Projeta uma imagem interessante do futuro para seus seguidores. 2_l_3

11) Promove a cooperação entre os grupos de trabalho. 4 I_4

12) Percebe um problema do passado como uma oportunidade de melhoria no presente. 4_/_5_

13) Mantém a calma durante situações de crise. _1_/_1_

14) Dá atenção individualizada para ajudar cada membro a cumprir seus objetivos, fazendo um papel de mentor ou treinador. _3_/_3_

15) Motiva o grupo para trabalhar junto em busca do mesmo objetivo. -3_I4_

* A pontuação será invertida

Escala:

15 45

Líder Transacional 75

Líder Transformacional 
Percepção de desempenho empresarial do gestor da empresa A.

1 - Discordo plenamente

2 - Apenas Discordo

3 - Não Concordo nem discordo

4 - Apenas Concordo

5 - Concordo plenamente

1) Mercado e Consumidor

a) Sua empresa é líder no seu mercado. Ela possui pelo menos $25 \%$ de participação de mercado na região que ela atua._5_/_5

b) Os serviços oferecidos por sua empresa estão acima da média do mercado._5_5

c) Seus clientes estão satisfeitos com o atendimento da sua empresa e preferem pagar até um pouco mais pelos seus produtos. [5_/_5_

d) Os produtos são de boa qualidade e as queixas são poucas com relação a prazos de entrega e pagamento._5_/_5_

e) Sua empresa inova mais do que a maior parte das empresas do seu mercado._4___3_

2) Resultados Financeiros

a) Sua empresa tem uma boa saúde financeira. As contas são pagas em dia. 5_/_5

b) Nos últimos três anos você percebeu um crescimento nas vendas. _3_/_2

c) Os ativos, inclusive estoque, de sua empresa cresceram no mesmo período. 5_/ 5

d) Os salários da sua empresa aumentaram em relação à média do mercado. 5_l_4_

e) Existe uma maior delegação de poder e um aumento dos funcionários nos últimos três anos. _3_/_4_

3) Satisfação dos Funcionários

a) Você fala para seus amigos que trabalha numa boa organização. _4_/_5_

b) Você tem uma boa relação com seu chefe. 2 2 / 1_

c) Os valores dessa empresa são parecidos $\operatorname{com}^{-}$seus valores pessoais. 4_l_4

d) As pessoas estão comprometidas diariamente com o trabalho. _2___1_

e) Você considera sua remuneração justa pelo seu nível de instrução, experiência profissional e trabalho desempenhado._2_l_3_-

Escala:

15 45

Baixo Desempenho

Alto Desempenho 75 
2) Identificação das Fases de Diferenciação do Ciclo de Vida Organizacional

Empresa A - Marcar em vermelho a resposta equivalente no quadro

\begin{tabular}{|c|c|c|c|c|c|}
\hline & Fase 1 & Fase 2 & Fase 3 & Fase 4 & Fase 5 \\
\hline Diferenciação & Criação & Direção & Delegação & Coordenação & Reinvenção \\
\hline Foco & $\begin{array}{l}\text { Desenvolvim } \\
\text { ento de } \\
\text { Produto }\end{array}$ & $\begin{array}{l}\text { Expansão da } \\
\text { Capacidade }\end{array}$ & $\begin{array}{l}\text { Eficiência } \\
\text { Operacional }\end{array}$ & $\begin{array}{c}\text { Cliente e } \\
\text { Ganhos }\end{array}$ & $\begin{array}{l}\text { Cliente e } \\
\text { Novos } \\
\text { Produtos }\end{array}$ \\
\hline Período & Imediato & $\begin{array}{l}\text { Curto Prazo - } \\
\text { Até } 3 \text { meses }\end{array}$ & $\begin{array}{c}\text { Curto Prazo } \\
3 \text { meses a } 1 \text { ano }\end{array}$ & $\begin{array}{l}\text { Médio Prazo } \\
\text { - } 3 \text { anos }\end{array}$ & $\begin{array}{c}\text { Longo Prazo - } \\
5 \text { anos }\end{array}$ \\
\hline Estrutura & $\begin{array}{l}\text { Horizontal e } \\
\text { Genérica }\end{array}$ & $\begin{array}{c}\text { Hierárquica e } \\
\text { Funcional }\end{array}$ & $\begin{array}{c}\text { Hierárquica e } \\
\text { Especializada } \\
\text { Descentralizada }\end{array}$ & $\begin{array}{l}\text { Baseada em } \\
\text { produto e } \\
\text { Centralizada }\end{array}$ & $\begin{array}{c}\text { Horizontal, } \\
\text { matricial e } \\
\text { mesclada/mist } \\
\text { urada }\end{array}$ \\
\hline $\begin{array}{l}\text { Estilo de } \\
\text { Comunicação }\end{array}$ & $\begin{array}{c}\text { Muito } \\
\text { informal; } \\
\text { pessoal e } \\
\text { flexível e } \\
\text { Pessoal }\end{array}$ & $\begin{array}{c}\text { Começa a } \\
\text { emergir uma } \\
\text { formalização, } \\
\text { mas fraca }\end{array}$ & $\begin{array}{c}\text { Formal e } \\
\text { Burocrático }\end{array}$ & $\begin{array}{c}\text { Formal e } \\
\text { Distanciada } \\
\text { do Dia-a-dia }\end{array}$ & $\begin{array}{l}\text { Mista; formal } \\
\text { e informal }\end{array}$ \\
\hline $\begin{array}{l}\text { Tipo de } \\
\text { Comunicação }\end{array}$ & $\begin{array}{l}\text { Verbal e } \\
\text { Frequente }\end{array}$ & $\begin{array}{c}\text { Verbal e } \\
\text { quando } \\
\text { necessário }\end{array}$ & $\begin{array}{c}\text { Escrita; local e } \\
\text { corporativa }\end{array}$ & $\begin{array}{c}\text { Escrita; local e } \\
\text { corporativa }\end{array}$ & $\begin{array}{c}\text { Mista; local e } \\
\text { corporativa }\end{array}$ \\
\hline Decisão & $\begin{array}{c}\text { Centralizada } \\
\text { e Rápida }\end{array}$ & Centralizada & $\begin{array}{c}\text { Decentralizada } \\
\text { Mediana/ } \\
\text { Dividida com } \\
\text { outros gerentes }\end{array}$ & $\begin{array}{c}\text { Produto - } \\
\text { Decentralizad } \\
\text { a; Suporte - } \\
\text { Central }\end{array}$ & $\begin{array}{c}\text { Decentralizad } \\
\text { a e Rápida }\end{array}$ \\
\hline $\begin{array}{l}\text { Sistemas de } \\
\text { Controles } \\
\text { /Processos }\end{array}$ & $\begin{array}{l}\text { Raros e } \\
\text { Informais } \\
\text { Simples e } \\
\text { visual }\end{array}$ & $\begin{array}{c}\text { Em } \\
\text { Desenvolvim } \\
\text { ento } \\
\text { Simples e } \\
\text { pessoal } \\
\end{array}$ & $\begin{array}{c}\text { Desenvolvido/B } \\
\text { ásicos } \\
\text { Sistemas de } \\
\text { controles } \\
\text { simples } \\
\end{array}$ & $\begin{array}{l}\text { Formal e } \\
\text { Detalhado }\end{array}$ & Simplificados \\
\hline
\end{tabular}

Harvard Business Review, 76, pag. 55-67

3) Lições Aprendidas - Entrevista líder empresa A para os cenários crise 2008 e 2015.

a) $\mathrm{O}$ que funcionou bem do ponto de vista de gestão e resultados, durante o período da crise de 2008 ?

Corte de Despesas e otimização de compras e estoque.

b) Quais foram os passos bem-sucedidos no sentido de alcançar o seu objetivo? Por quê?

Primeiro fizemos uma análise de projeção de vendas e adequamos as compras a nossa nova realidade e por consequência enxugamos algumas despesas para que o ponto de equilíbrio operacional diminuísse também.

c) O que poderia ser repetido em 2015 do que foi bem sucedido em 2008?

A intervenção em compras para controlar os gastos.

d) O que não funcionou tão bem, do ponto de vista de gestão e resultados, durante o período da crise de 2008? Por quê?

O corte nos gastos, pois o nosso custo fixo é muito grande e os pequenos cortes não impactaram muito no resultado final.

e) $\mathrm{O}$ que poderia ter ido melhor? O que não foi uma nota 10? E o que faria um dez para você?

Poderíamos ter lançado novos produtos e atuar em novos mercados.

f) Se você tivesse possibilidade de voltar em 2008 o que você faria diferente, no que diz respeito a gestão da empresa? Por quê?

Mesma resposta da anterior. 


\section{Anexo 2 \\ Empresa B - Resposta Líder}

Definindo os estilos de liderança

1 - Discordo plenamente

2 - Apenas Discordo

3 - Não Concordo nem discordo

4 - Apenas Concordo

5 - Concordo plenamente

2009 / 2015

1) Você é recompensado de acordo com o cumprimento de suas tarefas*. 3_l_3

2) $\overline{\mathrm{O}} \mathrm{seu}$ chefe fica atento todo dia com os processos do dia-a-dia e toma ações corretivas quando alguma coisa não sai como ele imaginou ou quando há descumprimento das normas*. 3_/ 2

3) Seu líder só atua quando há descumprimento das regras*. _____ 2

4) Seu líder evita tomar decisões e se exime de responsabilidades*.

5) As atitudes do seu líder fazem com que seus seguidores o respeitem.

6) $\overline{\text { Você }}$ - sente orgulho de trabalhar para seu líder. _ 3 _/_4_

7) Seu líder encara de forma séria as necessidades pessoais dos colaboradores. 4 4 4 _

8) Ele mostra respeito pelos sentimentos individuais dos seguidores. 5_/5

9) $\overline{\text { Passa }}$ por cima de seus interesses para o bem dos colaboradores. __ 3_ 4

10) Projeta uma imagem interessante do futuro para seus seguidores. 3_l_4

11) Promove a cooperação entre os grupos de trabalho. __ 4_/_4

12) Percebe um problema do passado como uma oportunidade de melhoria no presente. 4 ___ 4

13) Mantém a calma durante situações de crise. _3_/_4

14) Dá atenção individualizada para ajudar cada membro a cumprir seus objetivos, fazendo um papel de mentor ou treinador. _2__3

15) Motiva o grupo para trabalhar junto em busca do mesmo objetivo. -4_l_5

* A pontuação será invertida

Escala:

15 45

Líder Transacional

Líder Transformacional 75 
Percepção de desempenho empresarial do gestor da empresa B.

1 - Discordo plenamente

2 - Apenas Discordo

3 - Não Concordo nem discordo

4 - Apenas Concordo

5 - Concordo plenamente

1) Mercado e Consumidor

a) Sua empresa é líder no seu mercado. Ela possui pelo menos $25 \%$ de participação de mercado na região que ela atua. _4_/_4

b) Os serviços oferecidos por sua empresa estão acima da média do mercado. 4 / 5

c) Seus clientes estão satisfeitos com o atendimento da sua empresa e preferem pagar até um pouco mais pelos seus produtos. 3 __ 4

d) Os produtos são de boa qualidade e as queixas são poucas com relação a prazos de entrega e pagamento._4__ 4

e) Sua empresa inova mais do que a maior parte das empresas do seu mercado._5_/_5_

2) Resultados Financeiros

a) Sua empresa tem uma boa saúde financeira. As contas são pagas em dia._3_/_4

b) Nos últimos três anos você percebeu um crescimento nas vendas. $5 / 4$

c) Os ativos, inclusive estoque, de sua empresa cresceram no mesmo período. 4_/_4_

d) Os salários da sua empresa aumentaram em relação à média do mercado._3__ 4 _

e) Existe uma maior delegação de poder e um aumento dos funcionários nos últimos três anos. _3_/_4

3) Satisfação dos Funcionários

a) Você fala para seus amigos que trabalha numa boa organização. 4_l_4

b) Você tem uma boa relação com seu chefe. _4_/_5

c) Os valores dessa empresa são parecidos com seus valores pessoais. 3_l_4

d) As pessoas estão comprometidas diariamente com o trabalho. 33/_3

e) Você considera sua remuneração justa pelo seu nível de instrução, experiência profissional e trabalho desempenhado. 3_ /_4

Escala:

15 45

Baixo Desempenho 75

Alto Desempenho 
2) Identificação das Fases de Diferenciação do Ciclo de Vida Organizacional

Empresa B - Marcar em vermelho a resposta equivalente no quadro

\begin{tabular}{|c|c|c|c|c|c|}
\hline & Fase 1 & Fase 2 & Fase 3 & Fase 4 & Fase 5 \\
\hline Diferenciação & Criação & Direção & Delegação & Coordenação & Reinvenção \\
\hline Foco & $\begin{array}{l}\text { Desenvolvi } \\
\text { mento de } \\
\text { Produto }\end{array}$ & $\begin{array}{l}\text { Expansão da } \\
\text { Capacidade }\end{array}$ & $\begin{array}{l}\text { Eficiência } \\
\text { Operacional }\end{array}$ & $\begin{array}{l}\text { Cliente e } \\
\text { Ganhos }\end{array}$ & $\begin{array}{l}\text { Cliente e } \\
\text { Novos } \\
\text { Produtos }\end{array}$ \\
\hline Período & Imediato & $\begin{array}{l}\text { Curto Prazo - } \\
\text { Até } 3 \text { meses }\end{array}$ & $\begin{array}{c}\text { Curto Prazo } \\
3 \text { meses a } 1 \text { ano }\end{array}$ & $\begin{array}{l}\text { Médio Prazo } \\
-3 \text { anos }\end{array}$ & $\begin{array}{l}\text { Longo Prazo - } \\
5 \text { anos }\end{array}$ \\
\hline Estrutura & $\begin{array}{l}\text { Horizontal } \\
\text { e Genérica }\end{array}$ & $\begin{array}{l}\text { Hierárquica e } \\
\text { Funcional }\end{array}$ & $\begin{array}{c}\text { Hierárquica e } \\
\text { Especializada } \\
\text { Descentralizada }\end{array}$ & $\begin{array}{l}\text { Baseada em } \\
\text { produto e } \\
\text { Centralizada }\end{array}$ & $\begin{array}{c}\text { Horizontal, } \\
\text { matricial e } \\
\text { mesclada/mist } \\
\text { urada }\end{array}$ \\
\hline $\begin{array}{l}\text { Estilo de } \\
\text { Comunicação }\end{array}$ & $\begin{array}{l}\text { Muito } \\
\text { informal; } \\
\text { pessoal e } \\
\text { flexível e } \\
\text { Pessoal }\end{array}$ & $\begin{array}{c}\text { Começa a } \\
\text { emergir uma } \\
\text { formalização, } \\
\text { mas fraca }\end{array}$ & $\begin{array}{l}\text { Formal e } \\
\text { Burocrático }\end{array}$ & $\begin{array}{c}\text { Formal e } \\
\text { Distanciada do } \\
\text { Dia-a-dia }\end{array}$ & $\begin{array}{l}\text { Mista; formal e } \\
\text { informal }\end{array}$ \\
\hline $\begin{array}{l}\text { Tipo de } \\
\text { Comunicação }\end{array}$ & $\begin{array}{l}\text { Verbal e } \\
\text { Frequente }\end{array}$ & $\begin{array}{l}\text { Verbal e quando } \\
\text { necessário }\end{array}$ & $\begin{array}{l}\text { Escrita; local e } \\
\text { corporativa }\end{array}$ & $\begin{array}{c}\text { Escrita; local e } \\
\text { corporativa }\end{array}$ & $\begin{array}{l}\text { Mista; local e } \\
\text { corporativa }\end{array}$ \\
\hline Decisão & $\begin{array}{l}\text { Centralizada } \\
\text { e Rápida }\end{array}$ & Centralizada & $\begin{array}{l}\text { Decentralizada } \\
\text { Ou Dividida com } \\
\text { outros gerentes }\end{array}$ & $\begin{array}{l}\text { Produto - } \\
\text { Decentralizada; } \\
\text { Suporte - } \\
\text { Central }\end{array}$ & $\begin{array}{l}\text { Decentralizada } \\
\text { e Rápida }\end{array}$ \\
\hline $\begin{array}{l}\text { Sistemas de } \\
\text { Controles } \\
\text { /Processos }\end{array}$ & $\begin{array}{l}\text { Raros e } \\
\text { Informais } \\
\text { Simples e } \\
\text { visual }\end{array}$ & $\begin{array}{c}\text { Em } \\
\text { Desenvolvimento } \\
\text { Simples e } \\
\text { pessoal }\end{array}$ & $\begin{array}{l}\text { Desenvolvido/ } \\
\text { Básicos } \\
\text { Sistemas de } \\
\text { controles } \\
\text { simples }\end{array}$ & $\begin{array}{l}\text { Formal e } \\
\text { Detalhado }\end{array}$ & Simplificados \\
\hline
\end{tabular}

3) Lições Aprendidas - Entrevista líder empresa B para os cenários crise 2008 e 2015.

a) $\mathrm{O}$ que funcionou bem do ponto de vista de gestão e resultados, durante o período da crise de 2008 ?

b) Quais foram os passos bem-sucedidos no sentido de alcançar o seu objetivo? Por quê?

c) O que poderia ser repetido em 2015 do que foi bem sucedido em 2008 ?

d) O que não funcionou tão bem, do ponto de vista de gestão e resultados, durante o período da crise de 2008? Por quê?

e) O que poderia ter ido melhor? O que não foi uma nota 10 ? E o que faria um dez para você?

f) Se você tivesse possibilidade de voltar em 2008 o que você faria diferente, no que diz respeito a gestão da empresa? Por quê?

Respostas para as perguntas: A crise de 2008 não afetou muito a empresa. 


\begin{tabular}{|c|c|c|c|c|c|c|c|c|c|c|c|c|c|c|c|c|}
\hline & \multicolumn{15}{|c|}{ Funcionários } \\
\hline & & $A$ & $B$ & $\mathrm{C}$ & D & $E$ & $F$ & $G$ & $\mathrm{H}$ & I & $\mathrm{J}$ & $L$ & $M$ & $\mathrm{~N}$ & $\mathrm{O}$ & $P$ \\
\hline \multirow{15}{*}{ 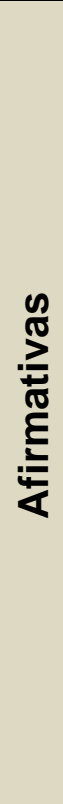 } & 1 & 3 & 2 & 3 & 2 & 1 & 4 & 4 & 2 & 3 & 3 & 1 & 4 & 4 & 3 & 2 \\
\hline & 2 & 4 & 3 & 2 & 2 & 5 & 1 & 3 & 4 & 3 & 3 & 4 & 2 & 2 & 4 & 2 \\
\hline & 3 & 3 & 2 & 3 & 2 & 3 & 4 & 3 & 3 & 4 & 5 & 3 & 2 & 3 & 5 & 3 \\
\hline & 4 & 4 & 3 & 2 & 4 & 4 & 5 & 3 & 3 & 4 & 3 & 5 & 3 & 2 & 2 & 3 \\
\hline & 5 & 2 & 1 & 2 & 1 & 2 & 2 & 3 & 2 & 1 & 2 & 3 & 3 & 3 & 1 & 2 \\
\hline & 6 & 2 & 1 & 1 & 2 & 3 & 3 & 4 & 2 & 3 & 2 & 1 & 2 & 3 & 2 & 4 \\
\hline & 7 & 1 & 2 & 2 & 1 & 3 & 3 & 1 & 1 & 3 & 3 & 2 & 3 & 2 & 2 & 1 \\
\hline & 8 & 2 & 1 & 3 & 2 & 2 & 1 & 2 & 2 & 1 & 2 & 2 & 1 & 2 & 1 & 1 \\
\hline & 9 & 2 & 3 & 1 & 4 & 1 & 2 & 2 & 2 & 4 & 2 & 3 & 3 & 3 & 2 & 3 \\
\hline & 10 & 3 & 2 & 3 & 4 & 3 & 2 & 3 & 2 & 2 & 2 & 1 & 2 & 3 & 3 & 2 \\
\hline & 11 & 1 & 2 & 1 & 2 & 2 & 1 & 2 & 3 & 1 & 2 & 1 & 2 & 2 & 2 & 1 \\
\hline & 12 & 3 & 2 & 4 & 2 & 3 & 4 & 2 & 2 & 3 & 2 & 3 & 2 & 1 & 2 & 3 \\
\hline & 13 & 1 & 2 & 1 & 1 & 1 & 2 & 1 & 3 & 1 & 3 & 1 & 2 & 1 & 3 & 1 \\
\hline & 14 & 3 & 2 & 2 & 3 & 1 & 1 & 2 & 3 & 2 & 2 & 1 & 3 & 3 & 2 & 3 \\
\hline & 15 & 3 & 2 & 2 & 3 & 2 & 2 & 1 & 1 & 1 & 2 & 1 & 2 & 2 & 3 & 1 \\
\hline
\end{tabular}

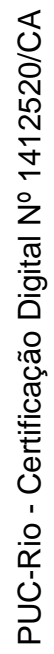

